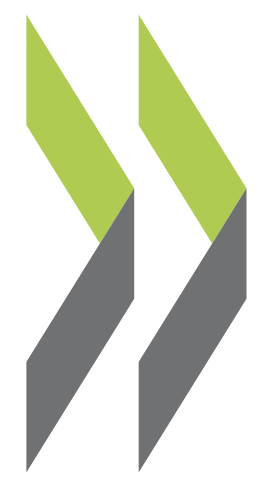

OECD Economics Department Working Papers No. 1325

Labour market reforms

in Korea to promote inclusive growth
Randall S. Jones, Kohei Fukawa 
Organisation de Coopération et de Développement Économiques

Organisation for Economic Co-operation and Development

29-Sep-2016

ECONOMICS DEPARTMENT

English - Or. English

Cancels \& replaces the same document of 27 September 2016

\section{LABOUR MARKET REFORMS IN KOREA TO PROMOTE INCLUSIVE GROWTH}

ECONOMICS DEPARTMENT WORKING PAPERS No. 1325

By Randall S. Jones and Kohei Fukawa

OECD Working Papers should not be reported as representing the official views of the OECD or of its member countries. The opinions expressed and arguments employed are those of the authors.

Authorised for publication by Robert Ford, Deputy Director, Country Studies Branch, Economics Department.

All Economics Department Working Papers are available at www.oecd.org/eco/workingpapers

JT03401655

Complete document available on OLIS in its original format

This document and any map included herein are without prejudice to the status of or sovereignty over any territory, to the delimitation of international frontiers and boundaries and to the name of any territory, city or area. 
OECD Working Papers should not be reported as representing the official views of the OECD or of its member countries. The opinions expressed and arguments employed are those of the author(s).

Working Papers describe preliminary results or research in progress by the author(s) and are published to stimulate discussion on a broad range of issues on which the OECD works.

Comments on Working Papers are welcomed, and may be sent to the Economics Department, OECD, 2 rue André-Pascal, 75775 Paris Cedex 16, France, or by e-mail to econ.contact@ oecd.org.

All Economics Department Working Papers are available at www.oecd.org/eco/workingpapers.

This document and any map included herein are without prejudice to the status of or sovereignty over any territory, to the delimitation of international frontiers and boundaries and to the name of any territory, city or area.

The statistical data for Israel are supplied by and under the responsibility of the relevant Israeli authorities. The use of such data by the OECD is without prejudice to the status of the Golan Heights, East Jerusalem and Israeli settlements in the West Bank under the terms of international law.

Latvia was not an OECD member at the time of preparation of this publication. Accordingly, Latvia does not appear in the list of OECD Members and is not included in the zone aggregates.

\section{(C) OECD (2016)}

You can copy, download or print OECD content for your own use, and you can include excerpts from OECD publications, databases and multimedia products in your own documents, presentations, blogs, websites and teaching materials, provided that suitable acknowledgment of OECD as source and copyright owner is given. All requests for commercial use and translation rights should be submitted to rights@oecd.org 
ECO/WKP(2016)49

\section{ABSTRACT/RÉSUMÉ \\ Labour market reforms in Korea to promote inclusive growth}

Labour market reforms are essential to promote social cohesion by removing obstacles to employment, particularly for women, youth and older persons. In addition to reducing income inequality and poverty, such reforms would also sustain economic growth as Korea's working-age population begins to decline in 2017. Breaking down labour market duality is crucial to reduce the wide wage disparity. Better conditions for non-regular workers would in turn promote greater labour participation. Increasing the take-up of maternity and parental leave, expanding the availability of high-quality childcare, reducing working time, narrowing the large gender wage gap and eliminating discrimination would also increase opportunities for women. Boosting youth employment from its current low level requires addressing labour market mismatch by better aligning the skills learned in school with those demanded by employers. Reducing the emphasis on seniority in setting wages by moving to more flexible systems and expanding training to improve the skills of older persons would allow them to extend their careers, thereby reducing old-age poverty.

This Working Paper relates to the 2016 OECD Economic Survey of Korea (www.oecd.org/eco/surveys/economic-survey-korea.htm)

JEL classification: J21, J24, J26, J31.

Keywords: labour market; dualism; non-regular workers; work-life balance; basic pension.

***********************************

\section{Des réformes du marché du travail en Corée pour promouvoir une croissance inclusive}

Les réformes du marché du travail sont essentielles pour promouvoir la cohésion sociale en supprimant les obstacles à l'emploi, en particulier pour les femmes, les jeunes et les personnes âgées. En plus de réduire l'inégalité de revenus et la pauvreté, de telles réformes soutiendraient la croissance économique, alors que la population en âge de travailler en Corée commence à décliner en 2017. Mettre fin au dualisme du marché du travail est crucial pour réduire la forte disparité des salaires. De meilleures conditions pour les travailleurs non réguliers favoriseraient à leur tour une participation accrue au marché du travail. L'augmentation de la prise de congés de maternité et parental, l'expansion de la disponibilité des services de garde d'enfants de haute qualité, une réduction du temps de travail, une réduction de l'important écart salarial entre hommes et femmes et l'élimination des discriminations accroîtraient les opportunités pour les femmes. Pour augmenter l'emploi des jeunes à partir de son faible niveau actuel, il est nécessaire de traiter le problème de l'inadéquation de l'offre et de la demande de travail par une meilleure adéquation entre les compétences acquises à l'école avec celles exigées par les employeurs. Réduire l'accent sur l'ancienneté dans la fixation des salaires en introduisant des systèmes plus flexibles et élargir la formation pour améliorer les compétences des plus anciens permettraient à ces derniers de prolonger leur carrière, réduisant ainsi la pauvreté des personnes âgées.

Ce Document de travail a trait à l'Étude économique de l'OCDE de la Corée, 2016 (http://www.oecd.org/fr/eco/etudes/etude-economique-coree.htm).

Classification JEL : J21, J24, J26, J31.

Mots clés: réforme du marché du travail, dualisme, travailleurs non réguliers, équilibre vie professionnelle-vie privée, retraite de base. 


\section{TABLE OF CONTENTS}

\section{LABOUR MARKET REFORMS IN KOREA TO PROMOTE INCLUSIVE GROWTH ..........................6}

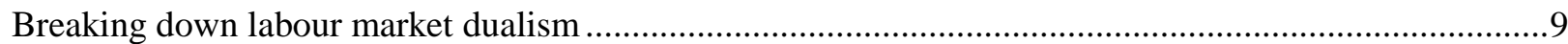

Non-regular workers fare poorly in terms of income, consumption and marriage ...............................

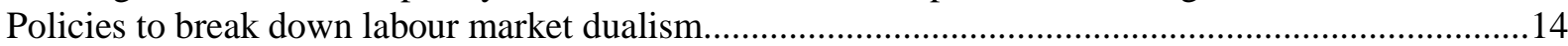

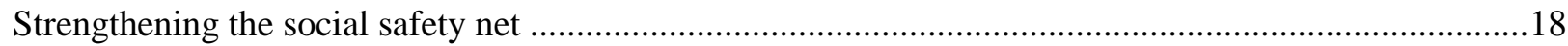

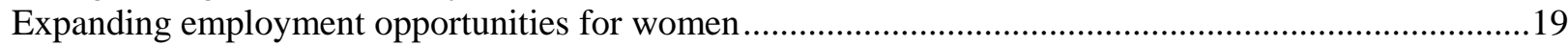

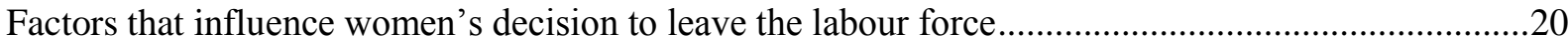

Facilitating women's return to work after an absence from the labour market....................................28

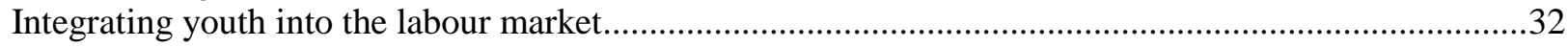

Mismatch problems in the labour market for youth ...........................................................................33

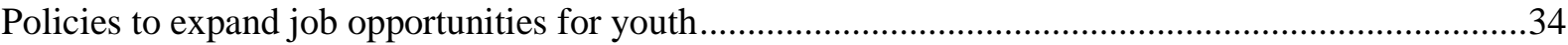

Making better use of older workers to promote inclusive growth and reduce poverty..............................35

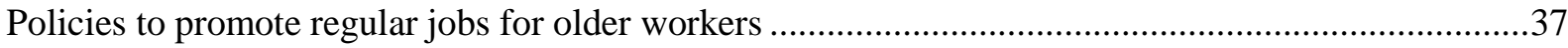

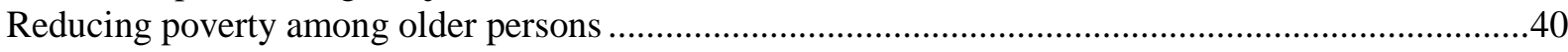

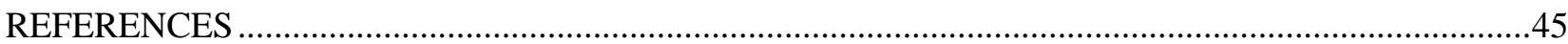

\section{Tables}

Table 1. The employment rate targets set by the roadmap ...................................................................

Table 2. Non-regular workers account for about a third of employees and earn much less .....................10

Table 3. A comparison of regular and non-regular workers ................................................................11

Table 4. Non-regular workers receive less social insurance and company-based benefits........................16

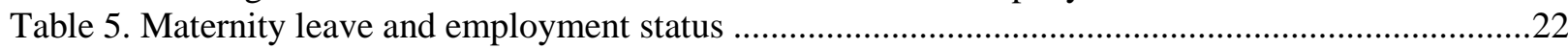

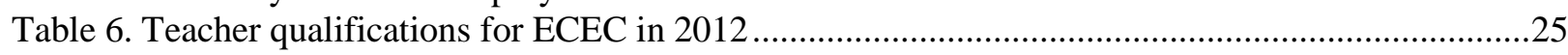

Table 7. A period of inactivity for youth has a long-term negative impact on labour market outcomes...35

\section{Figures}

Figure 1. Korea has a wide wage dispersion and a high share of low-wage workers...............................6

Figure 2. Increased female employment would mitigate the impact of demographic change .....................8

Figure 3. Income inequality and relative poverty have declined in recent years, but remain high .............9

Figure 4. Job tenure in Korea is relatively short due to the high share of temporary workers ..................11

Figure 5. The gap in income and expenditure between regular and non-regular workers is large ............12

Figure 6. The relative poverty rate is much higher in non-regular households .......................................13

Figure 7. Spending on education is much higher in households headed by regular workers ....................14

Figure 8. The minimum wage relative to the median wage in Korea is near the OECD average .............17

Figure 9. The impact of taxes and transfers on income inequality and poverty is weak in Korea.............19

Figure 10. The income level provided by cash minimum-income benefits in Korea is low ....................20

Figure 11. Korea's female employment rate still had a M-shaped pattern in 2014 .................................20

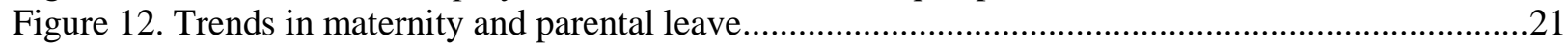

Figure 13. Central government expenditures on ECEC have risen sharply ..........................................23

Figure 14. Childcare enrolment increased sharply in Korea but the employment rate of mothers remains

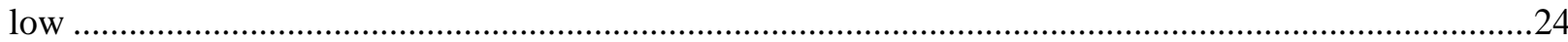


Figure 15. Working hours in Korea were long for both men and women in 2014 ...............................26

Figure 16. Korea's gender wage gap rises with age and is the largest in the OECD ..............................29

Figure 17. Educated women in Korea have a relatively low employment rate .........................................30

Figure 18. Women are concentrated in low-paying non-regular jobs.................................................

Figure 19. Women are concentrated in sectors with low wages .........................................................31

Figure 20. The share of women in management in Korea was the lowest in the OECD in 2013 .............31

Figure 21. Korea's youth employment rate has fallen and is well below the OECD average ...................32

Figure 22. Korea has a relatively high rate of mismatch among young people ........................................33

Figure 23. The rate of NEETs in Korea is higher for tertiary graduates ................................................34

Figure 24. Relative poverty rates for persons over 50 are very high in Korea ......................................36

Figure 25. Older workers in Korea are concentrated in temporary, low-paying jobs................................37

Figure 26. The education and skill gap between younger and older workers in Korea is large ................38

Figure 27. Youth employment rates are positively correlated with those of older workers in the OECD 39

Figure 28. The share of older workers receiving vocational education and training in Korea is low........40

Figure 29. The first-tier pension benefit in Korea is very low while the coverage is high ......................42

Figure 30. The National Pension Scheme is projected to fall into deficit in 2044 ..................................43

\section{Boxes}

Box 1. The Tripartite Agreement on Structural Reforms of the Labour Market .......................................

Box 2. Policies implemented or proposed to break down labour market dualism...................................15

Box 3. Policies to combine school and work experience at the secondary level ......................................36

Box 4. Recommendations for labour market reforms to promote inclusive growth ..................................44 


\title{
LABOUR MARKET REFORMS IN KOREA TO PROMOTE INCLUSIVE GROWTH
}

\author{
By Randall S. Jones and Kohei Fukawa ${ }^{l}$
}

Korea has a track record of rapid output and employment growth. Since 2001, output growth has averaged nearly $4 \%$ per year, while the unemployment rate remained below $4 \%$. However, faced with slowing growth and higher inequality and relative poverty, Korea launched an initiative in 2013 to shift from its traditional model of export-led growth driven by large manufacturing firms affiliated with chaebols toward a creative economy propelled by knowledge, information, and services (2016 OECD Economic Survey of Korea). However, the labour market, which was shaped by the era of rapid growth, is inadequate to meet this challenge. Labour market reforms are needed to promote flexibility and job creation, particularly for youth. It is also essential to address wage inequality: almost a quarter of full-time workers in 2013 earned less than two-thirds of the median wage, the second-highest share in the OECD, and wage dispersion was one of the highest (Figure 1). To cope with these challenges, the government, workers and employers announced a Tripartite Agreement on Structural Reforms of the Labour Market in September 2015 "to remove uncertainties and enhance efficiency in the labour market" (Box 1).

Figure 1. Korea has wide wage dispersion and a high share of low-wage workers

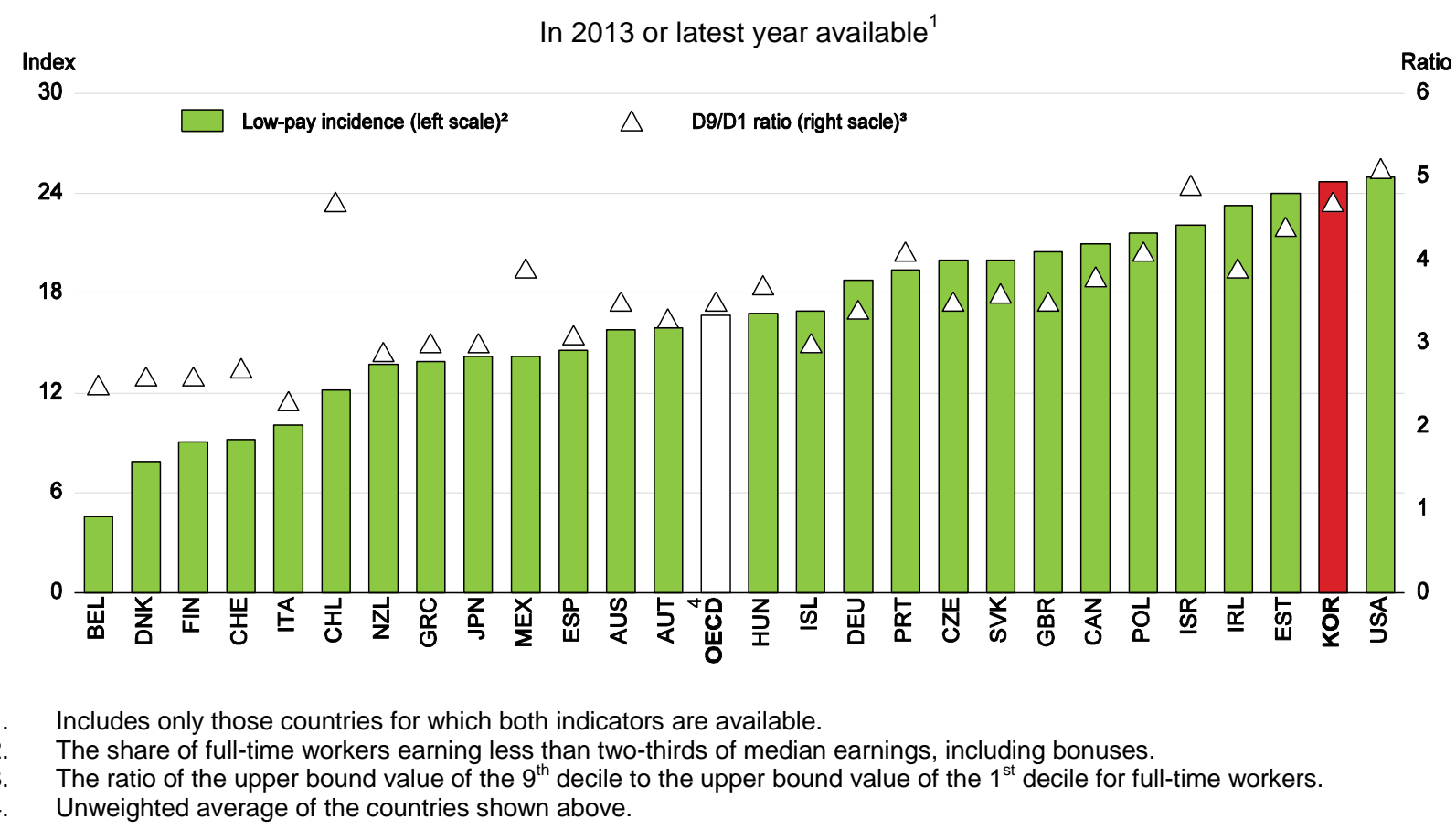

Source: OECD Income Distribution Database (http://www.oecd.org/employment/emp/employmentdatabase-earningsandwages.htm).

1. Randall S. Jones is head of the Japan/Korea Desk in the Economics Department of the OECD and Kohei Fukawa is an economist on that Desk. The authors would like to thank OECD colleagues (Willem Adema, Stéphane Carcillo and Hyunsook Kim from the Directorate for Employment, Labour and Social Affairs; Bert Brys, Centre for Tax Policy and Administration; Arno Engel and Yong-Seong Kim from the Directorate for Education and Skills; Robert Ford, Vincent Koen, Jae Wan Lee, and Alvaro Pereira from the Economics Department; and Andrew McQueen, Directorate for Education and Skills) and officials from the Korean government, for valuable comments on earlier drafts. Special thanks go to Shinya Kotera, who was a trainee in the Economics Department at the time of the preparation of the 2016 Economic Survey of Korea, for research assistance, Lutécia Daniel for technical assistance and Mercedes Burgos for technical preparation. 


\section{Box 1. The Tripartite Agreement on Structural Reforms of the Labour Market}

The Economic and Social Development Commission (ESDC) established a special committee for structural reforms of the labour market in September 2014. The committee included representatives of workers, employers and the government, as well as public interest groups. Labour was represented by the Federation of Korea Trade Unions (FKTU), while the second major confederation, the Korea Confederation of Trade Unions, which includes about $40 \%$ of unionised workers, refused to participate. The committee agreed to the Tripartite Agreement in September 2015 to:

\section{Increase youth employment:}

- $\quad$ Large firms and public enterprises will expand hiring of youth, with the government providing support.

- A youth employment promotion council will be created, including relevant ministries and private experts.

\section{Alleviate the dual structure of the labour market:}

- Promote shared growth through win-win co-operation between primary contractors and subcontractors, and large and small companies. The government will provide tax benefits to firms that establish welfare funds to improve the working conditions of their subcontractors.

- Improve non-regular employment practices and measures to prevent discrimination.

- Activate the labour market through policies to protect job security and clarify the standards and procedures for terminating employment contracts.

\section{Expand the social safety net:}

- Improve the coverage and efficiency of social insurance, including unemployment benefits.

- Improve employment support programmes for vulnerable groups and increase protection for them to raise their income.

- Gradually raise the minimum wage rate and increase compliance with the system.

- Provide stronger support for work-family balance.

- Tailor employment and welfare services to customers' needs.

- Promote skill development programmes to build a competency-based society.

\section{Eliminate uncertainties by addressing three key issues:}

- Clarify the definition of the ordinary wage (which now includes most bonus payments following a court ruling).

- Modify laws and institutions to help reduce actual working hours.

- Improve the wage system, in part through increased use of the wage peak system, to cope with the higher mandatory retirement age.

The planned measures in many of these areas will be discussed in this paper. However, as noted in the Agreement, "The tripartite partners shall have further discussions ... to clarify this Agreement". Consequently, the "Tripartite Agreement is not the end but simply the beginning of structural reforms in the labour market" (Economic and Social Development Commission, 2015). However, the FKTU renounced the Agreement in January 2016. According to the ESDC, the FKTU's decision does not nullify the Agreement and the government vows to press ahead with legislation to reform the labour market.

One of the goals of the Agreement is to address entrenched labour market dualism, as the large wage gap between regular and non-regular workers is the major cause of wage inequality and relative poverty (Figure 1). Labour market dualism has a number of other negative implications for non-regular workers: $i$ ) less coverage by the social safety net; $i$ ) precarious employment and the highest rate of worker turnover in the OECD; iii) less access to training, which has negative implications for output growth; and $i v$ ) less chance of marriage, leading to a lower fertility rate. The limited mobility between regular and non-regular employment (OECD, 2013b) reinforces the negative effect of dualism on social cohesion. Perhaps most importantly, dualism limits employment opportunities for major segments of the population.

In 2013, Korea announced a roadmap to boost employment, which was $64.2 \%$ of the working-age population in 2012 , to $70 \%$ by 2017 (Table 1) to strengthen the middle class and respond to low fertility and demographic change. The government is concerned about ageing, which is projected to be the most 
rapid in the OECD. If participation rates were to remain at their current levels for each age group and gender, the labour force would peak at 27.3 million in 2021 and then fall by $21 \%$, to around 21.6 million, by mid-century (Figure 2). By that point, there would be only 1.4 persons in the labour force per elderly person, compared with 5.1 in 2015, imposing a heavy burden on workers. In contrast, if the female participation rate for each age cohort were to rise to the rate for men by 2050 , the labour force would only fall to 25.5 million, $18 \%$ higher than in the case of unchanged participation rates. The roadmap includes four strategies: $i$ ) job creation by fostering a creative economy; $i$ ) mobilising untapped human resources by increasing the employment of women, youth and older persons; iii) reducing working hours and reforming work arrangements by expanding decent part-time work and promoting flexible work arrangements; and iv) strengthening social responsibility and co-operation between employers, workers and the government (MOEL, 2015). The employment rate rose by 1.5 percentage points between 2012 and 2015, despite sluggish economic growth.

Table 1. The employment rate targets set by the roadmap

As a percentage of the working-age population

\begin{tabular}{lrrrr|r|r|r}
\hline & $\mathbf{2 0 0 0}$ & $\mathbf{2 0 1 2}$ & $\mathbf{2 0 1 4}$ & $\mathbf{2 0 1 5}$ & $\mathbf{2 0 1 7}$ target & Gap & OECD average (2014) \\
\cline { 2 - 7 } Total & 61.5 & 64.2 & 65.3 & 65.7 & $\mathbf{7 0 . 0}$ & 4.3 & 65.8 \\
$\quad$ Women & 50.0 & 53.5 & 54.9 & 55.7 & $\mathbf{6 1 . 3}$ & 5.6 & 58.0 \\
Youth (15 to 29) & 43.4 & 40.4 & 40.7 & 41.5 & $\mathbf{4 6 . 6}$ & 5.1 & 51.2 \\
Adults (30 to 54) & 73.7 & 75.6 & 76.7 & 77.0 & $\mathbf{8 1 . 2}$ & 4.2 & 76.9 \\
Older persons (55 to 64) & 57.8 & 63.1 & 65.6 & 65.9 & $\mathbf{6 9 . 3}$ & 3.4 & 57.3 \\
\hline
\end{tabular}

Source: Government of Korea; OECD Employment Outlook Database (http://www.oecd.org/employment/emp/employment-outlookstatistical-annex.htm).

This paper first addresses the issue of labour market dualism, which has a major impact on inequality and social cohesion, as well as on labour force participation, and then discusses the scope for expanding the social safety net. The following sections examine policies to expand career opportunities for women, youth and older persons. The paper concludes with a set of recommendations (Box 4).

Figure 2. Increased female employment would mitigate the impact of demographic change

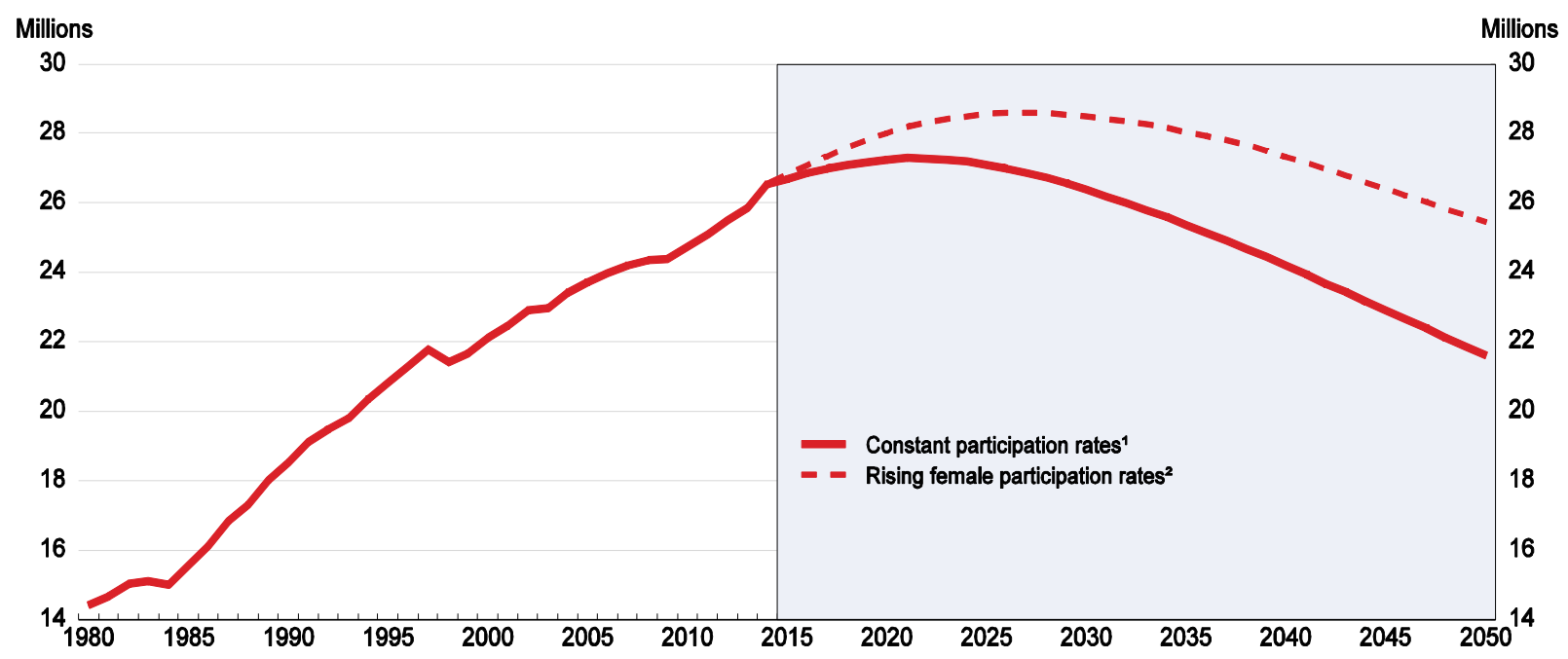

1. The participation rates for men and women are assumed to remain at their current levels for each age group.

2. Female participation rates are assumed to reach current male rates in each age group by 2050.

Source: Statistics Korea, Population Projection for Korea (2015) and Economically Active Population Survey; OECD calculations. 


\section{Breaking down labour market dualism}

Despite the growing impact of the tax and benefit system, income inequality and relative poverty among the urban population increased significantly between 1996 and 2009, before declining during the past few years (Figure 3). While ageing accounted for 32\% of the overall rise in inequality over 19962011, increased inequality among the working-age population was the main factor, accounting for 54\% (Chang and Lee, 2013). Indeed, the Gini coefficient for the labour income of urban households that have labour income rose from 0.33 in 1996 to 0.38 in 2010 (Choi, 2014). On a nationwide basis, the overall Gini coefficient (after-tax) was 0.302 in 2013, close to the OECD average. Nevertheless, the ratio of the $90^{\text {th }}$ income percentile to the $10^{\text {th }}$ is the seventh highest in the OECD. In addition, Korea's rate of relative poverty in 2013 was the eighth highest in the OECD.

Figure 3. Income inequality and relative poverty have declined in recent years, but remain high

\section{A. GInl coefflclent ${ }^{1}$}

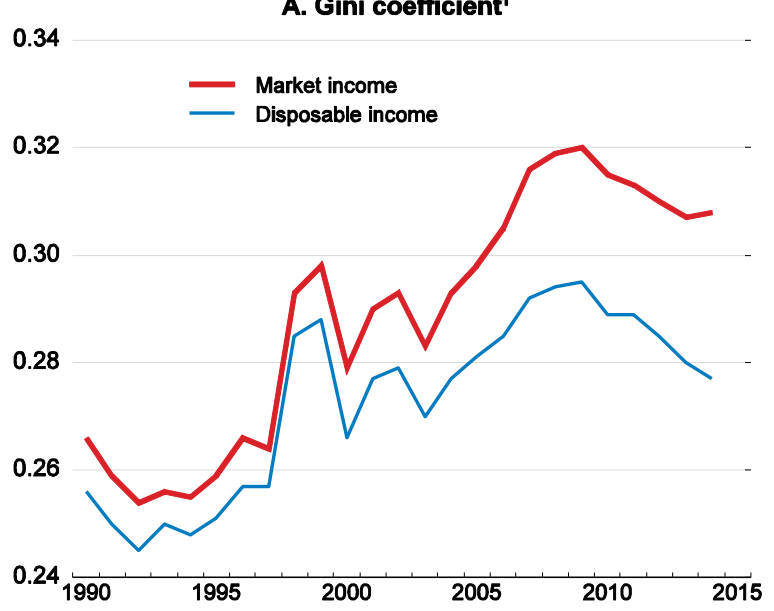

B. Relatlve poverty rate ${ }^{2}$

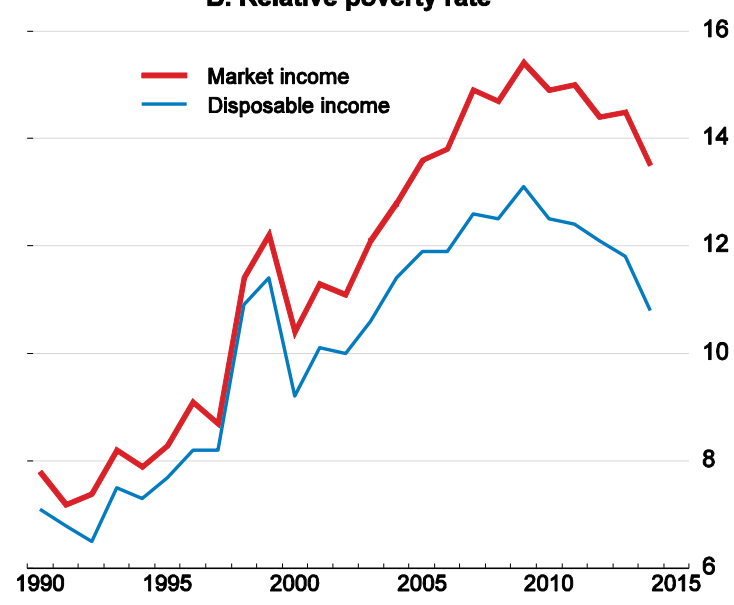

1. The Gini coefficient can range from 0 (perfect equality) to 1 (perfect inequality).

2. Relative poverty is defined as the percentage of the population with an income less than half of the national median.

Source: Statistics Korea.

Labour market dualism in Korea is exceptionally strong. Non-regular employees, such as fixed-term, part-time and dispatched workers, have accounted for around a third of dependent employment during the past decade (Table 2). The share of temporary workers among employees (22\%), who account for a majority of non-regular workers in Korea, was the fourth highest in the OECD area in 2014 and more than double the OECD average. However, their share has fallen while the share of part-time and other types of non-regular workers, who are paid less, has risen (Panel B). Consequently, the changing composition of non-regular employment has worsened inequality. According to surveys, firms hire non-regular workers to enhance employment flexibility and avoid the cost of laying off regular workers, who receive high employment protection as a result of labour laws and court decisions, and to reduce labour costs. According to a 2011 government survey, more than half of non-regular workers would prefer regular employment and are thus involuntarily employed as non-regular workers (OECD, 2013b), indicating that dualism is a result of labour market distortions.

\section{Non-regular workers fare poorly in terms of income, consumption and marriage}

Dualism is a major source of inequality, as non-regular workers were paid $36 \%$ less than regular workers in 2014 on an hourly basis. The large gap is inconsistent with employees' skill levels. According to the OECD study on the skills of adults, the literacy skills of temporary workers in Korea were equivalent to those of permanent prime-age workers ( 25 to 54 ) and even higher in the 16-24 age group (OECD, 
2013c). However, temporary workers are penalised by their relatively short tenure because of the strong link between tenure and wages in Korea. Indeed, the average tenure of non-regular workers in 2014 was only 30 months, compared to 85 months for regular workers. The large share of temporary workers lowers the overall job tenure in Korea: 54\% of workers in 2014 had worked less than three years for their firm, compared to an average of $32 \%$ in the OECD area (Figure 4). Short tenure discourages employee training, thus slowing the accumulation of human capital and productivity growth. Non-regular employment is most prevalent among youth and older workers, women, the less educated, workers in services and construction and employees of small firms (Table 3).

Table 2. Non-regular workers account for about a third of employees and earn much less

A. Employed persons by status

\begin{tabular}{|c|c|c|c|c|c|c|c|c|c|}
\hline \multirow{3}{*}{ Year } & \multirow{3}{*}{$\begin{array}{c}\text { Wage } \\
\text { workers }\end{array}$} & \multirow{3}{*}{\multicolumn{2}{|c|}{$\begin{array}{l}\text { Non-regular } \\
\text { workers }\end{array}$}} & \multicolumn{6}{|c|}{ Of which ${ }^{1}$} \\
\hline & & & & \multicolumn{3}{|c|}{ Contingent (temporary) workers } & \multirow[b]{2}{*}{$\begin{array}{c}\text { Part-time } \\
\text { workers }\end{array}$} & \multicolumn{2}{|c|}{ Atypical workers } \\
\hline & & & & Fixed-term & vorkers & $\begin{array}{l}\text { Open-ended } \\
\text { contract } \\
\text { workers }^{2}\end{array}$ & & Dispatched & Others \\
\hline & Thousand & Thousand & $\%$ & Thousand & $\%$ & $\%$ & $\%$ & $\%$ & $\%$ \\
\hline 2003 & 14149 & 4606 & 32.6 & 2403 & 52.2 & 13.3 & 20.2 & 2.1 & 34.3 \\
\hline 2005 & 14968 & 5483 & 36.6 & 2728 & 49.8 & 16.2 & 19.0 & 2.2 & 32.6 \\
\hline 2007 & 15882 & 5703 & 35.9 & 2531 & 44.4 & 17.8 & 21.1 & 3.1 & 35.7 \\
\hline 2009 & 16479 & 5754 & 34.9 & 2815 & 48.9 & 12.1 & 24.8 & 2.9 & 36.8 \\
\hline 2011 & 17510 & 5995 & 34.2 & 2668 & 44.5 & 13.0 & 28.4 & 3.3 & 37.2 \\
\hline 2014 & 18776 & 6077 & 32.4 & 2749 & 45.2 & 12.6 & 33.4 & 3.2 & 31.6 \\
\hline
\end{tabular}

B. Hourly wages of non-regular workers relative to regular workers (regular workers $=100$ )

\begin{tabular}{|c|c|c|c|c|c|c|c|}
\hline \multirow{3}{*}{ Year } & \multirow{3}{*}{$\begin{array}{l}\text { Regular } \\
\text { workers }\end{array}$} & \multirow{3}{*}{$\begin{array}{c}\text { Non-regular } \\
\text { workers }\end{array}$} & \multicolumn{5}{|c|}{ Of which $^{1}$} \\
\hline & & & \multicolumn{2}{|c|}{ Contingent (temporary) workers } & \multirow{2}{*}{$\begin{array}{l}\text { Part-time } \\
\text { workers }\end{array}$} & \multicolumn{2}{|c|}{ Atypical workers } \\
\hline & & & $\begin{array}{l}\text { Fixed-term } \\
\text { workers }\end{array}$ & $\begin{array}{c}\text { Open-ended } \\
\text { contract workers }^{2}\end{array}$ & & Dispatched & Others \\
\hline 2003 & 100.0 & 71.6 & 70.7 & 69.1 & 85.1 & 68.0 & n.a. \\
\hline 2005 & 100.0 & 70.5 & 74.5 & 66.0 & 76.7 & 76.1 & n.a. \\
\hline 2007 & 100.0 & 70.9 & 76.3 & 75.4 & 66.6 & 70.8 & n.a. \\
\hline 2009 & 100.0 & 61.5 & 65.5 & 58.2 & 56.2 & 69.7 & n.a. \\
\hline 2011 & 100.0 & 65.3 & 69.0 & 70.5 & 59.3 & 66.5 & n.a. \\
\hline 2014 & 100.0 & 64.3 & 67.8 & 67.5 & 54.0 & 60.8 & n.a. \\
\hline
\end{tabular}

1. The sum of the categories of non-regular workers exceeds $100 \%$ due to double-counting.

2. Workers whose employment contract term is not fixed but whose employment can continue through repeated renewals of the contract or is not expected to continue due to involuntary reasons.

Source: Statistics Korea, Economically Active Population Survey.

Lower wages result in lower income in households headed by a non-regular worker (Figure 5). Pretax income in a household headed by a regular worker in his or her 40s was $49 \%$ higher than in one headed by a non-regular worker and the gap rose to $88 \%$ for those aged 55-59. Most of the gap is explained by the difference in the income of the household head. For the population over age 60, the median annual income of non-regular households (after-tax on an equivalised basis) was 12 million KRW (around USD 10 500), which is just $8 \%$ above the relative poverty line. Marriage rates also show a marked difference. For nonregular households headed by a person in his or her 40 s, nearly $15 \%$ were single, more than double the share in a household headed by a regular worker. The low income and precarious status of non-regular workers discourages family creation and fertility, as only $2 \%$ of children are born outside of marriage, the lowest share in the OECD. 
ECO/WKP(2016)49

Table 3. A comparison of regular and non-regular workers

Incidence of non-regular employment in each category in August 2015

\begin{tabular}{|c|c|c|c|}
\hline A. Age & $\frac{\text { Under age } 30}{35.0}$ & $\frac{30 \text { to } 59}{26.8}$ & $\frac{\text { Over age } 60}{67.4}$ \\
\hline B. Gender & $\frac{\text { Male }}{26.5}$ & $\frac{\text { Female }}{40.2}$ & \\
\hline C. Education ${ }^{1}$ & $\frac{\text { Middle school or less }}{59.9}$ & $\frac{\text { High school }}{37.1}$ & $\frac{\text { Tertiary }}{21.4}$ \\
\hline D. Sector & $\frac{\text { Manufacturing }}{13.7}$ & $\frac{\text { Wholesale and retail }}{28.9}$ & $\frac{\text { Construction }}{52.3}$ \\
\hline E. Size of establishment & $\frac{\text { Less than } 5}{47.5}$ & $\frac{5 \text { to } 299}{31.7}$ & $\frac{\text { More than } 300}{14.0}$ \\
\hline
\end{tabular}

1. Ratio of temporary workers to wage workers.

Source: Statistics Korea, Economically Active Population Survey.

The large income gap is reflected, in turn, in a large disparity in spending. Disposable earned income in a household headed by a non-regular worker was $22-42 \%$ less than in a household headed by a regular worker for those over 40 (Figure 5, Panel B). Low income squeezes family budgets: the propensity to consume was $94 \%$ in households headed by a non-regular worker, compared to $76 \%$ in regular households. The low saving rate contributes to the household debt problem and slows the accumulation of savings for retirement. Despite the high propensity to consume, the level of consumption in non-regular households was $19-49 \%$ below that in regular households for each age group above 40 .

Poverty among the working-age population is closely linked to employment status. The relative poverty rate is much higher in households headed by a non-regular worker, at $16 \%$, compared to $5 \%$ in those headed by a regular worker or a self-employed worker (Figure 6). Moreover, the relative poverty rate is lower in households with one regular worker $(7 \%)$ than in those with two non-regular workers $(8 \%)$ (Panel B). The poverty rate rises to $22 \%$ for households with only one non-regular worker.

Figure 4. Job tenure in Korea is relatively short due to the high share of temporary workers

Percentage of employment by job tenure intervals in 2014

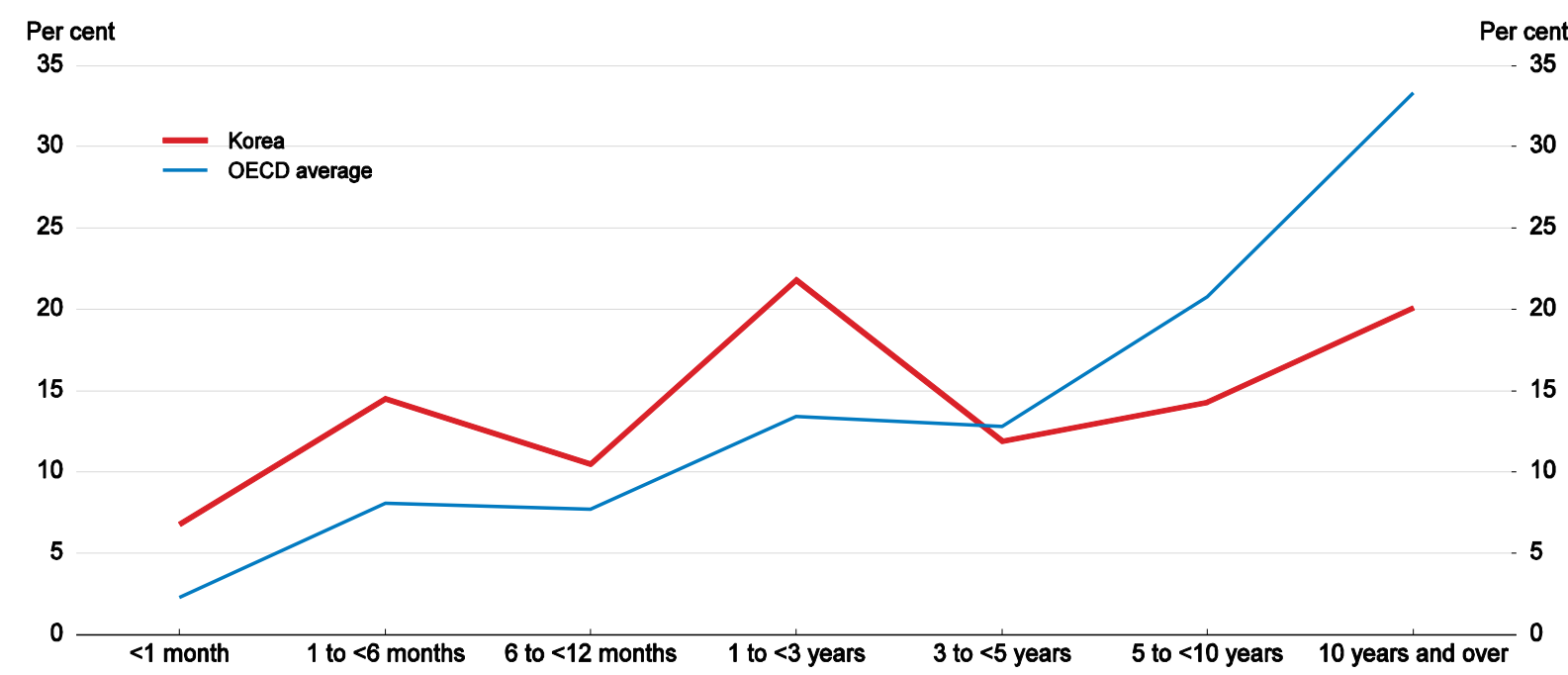

Source: OECD Employment, Labour and Social Affairs Database (https://stats.oecd.org/Index.aspx?DataSetCode=TENURE DIS). 
Figure 5. The gap in income and expenditure between regular and non-regular workers is large Households with two or more persons in $2011^{1}$

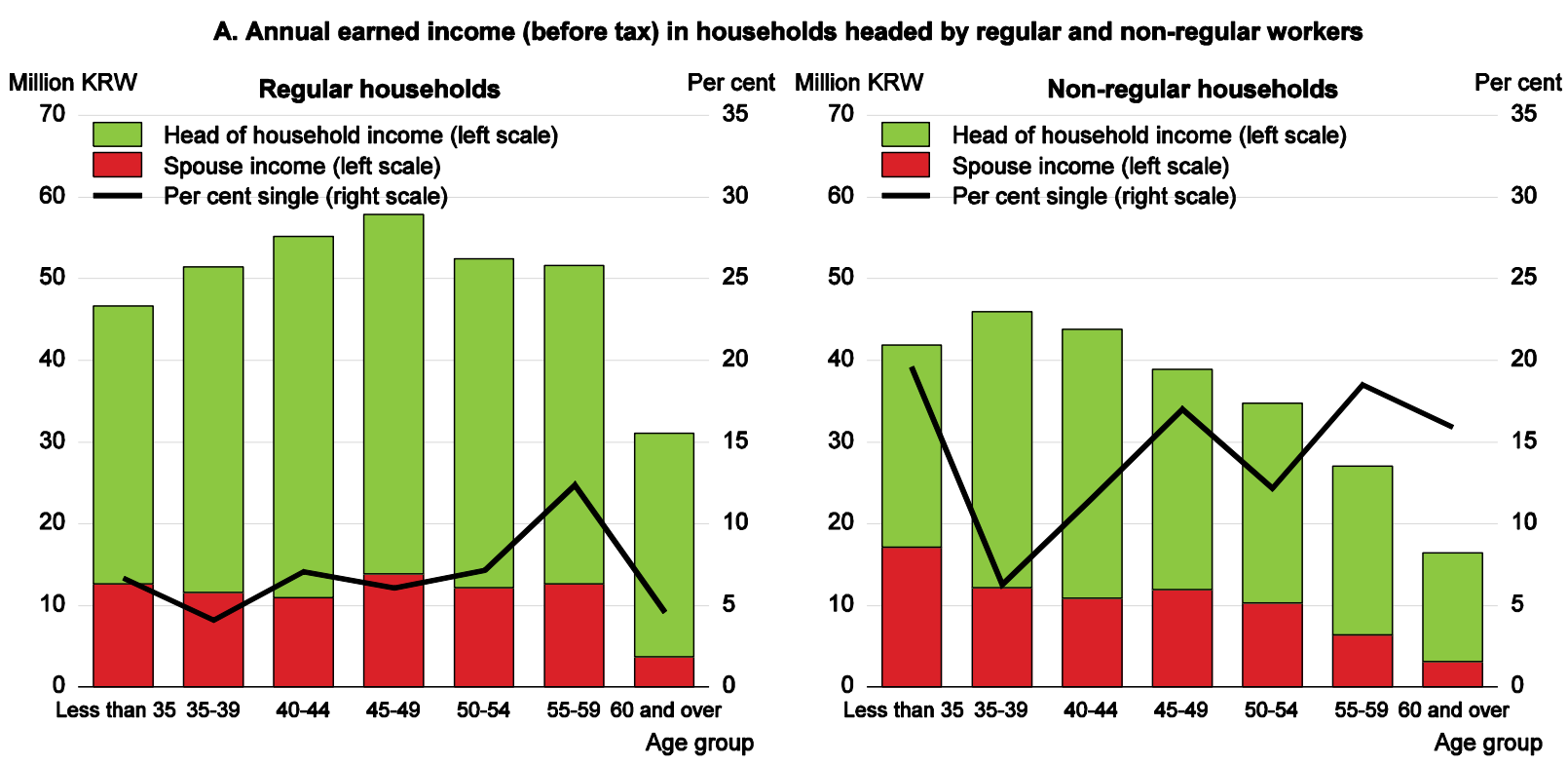

B. Households earned income (after tax) and expenditure per month ${ }^{2}$

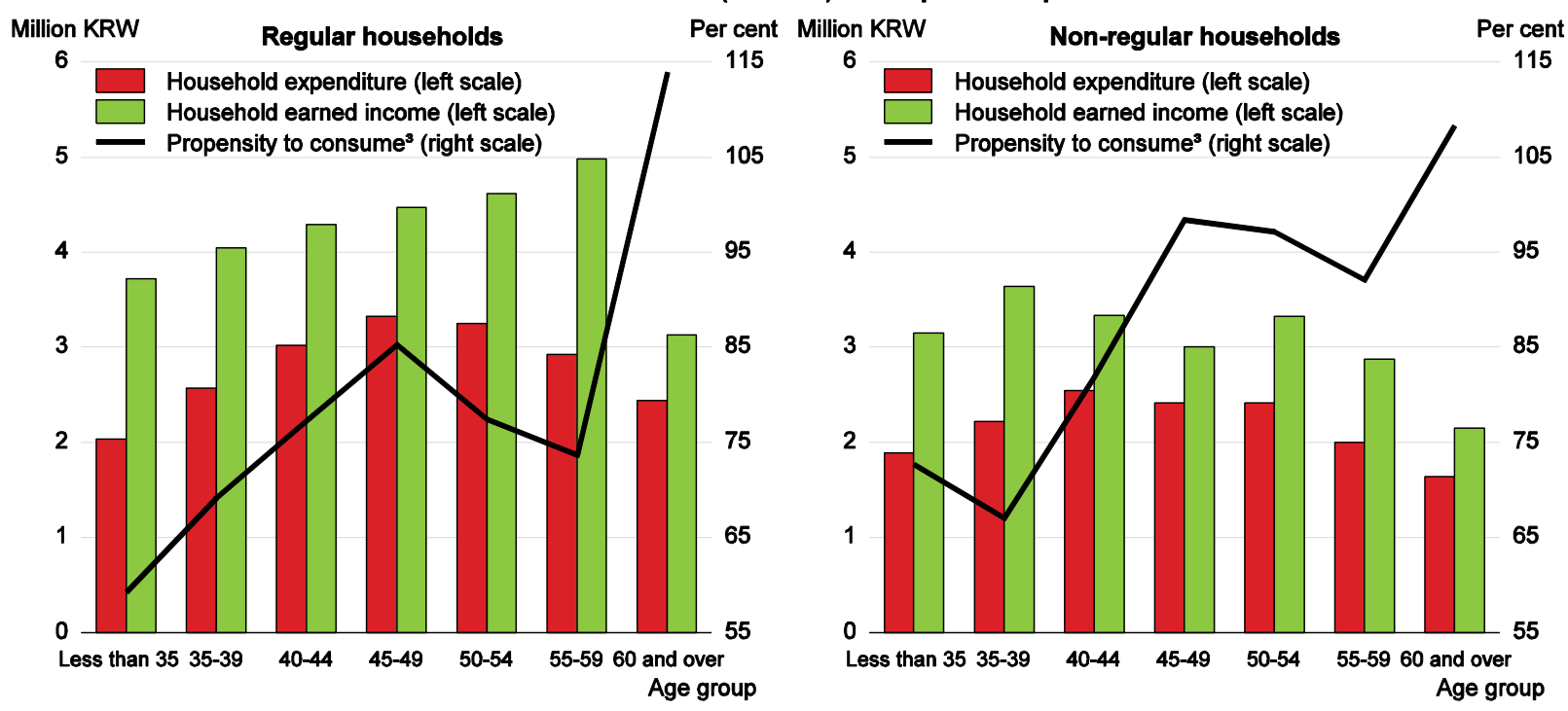

1. Based on the Korean Labour and Income Panel Survey (KLIPS), an annual household survey since 1998 that consists of about 6000 households (13000 individuals). Non-regular workers are identified using the official definition of non-regular workers, the same definition used in Strengthening Social Cohesion in Korea (OECD, 2013b). Job status and age category is that of the household head.

2. Contributions to the National Pension Scheme and National Health Insurance are included in expenditures. Household earned income equals annual income after taxes, divided by 12 .

3. Propensity to consume is the ratio of household expenditure to household earned income after tax.

Source: Korea Labour Institute, Korean Labour and Income Panel Survey (KLIPS); OECD calculations.

Labour market dualism has important equity implications for future generations. Spending on education in households headed by a non-regular worker is only $60 \%$ of that of regular households (Figure 7). For families with children under the age of 18, spending per child in households headed by a nonregular worker is $24 \%$ less than in those headed by a regular worker (Panel B). The gap is $34 \%$ in the case of private tutoring, including hagwons. Given the key role of private education in gaining entrance to top universities leading to high-paying jobs, children in non-regular households face a serious disadvantage. 
Figure 6. The relative poverty rate ${ }^{1}$ is much higher in non-regular households ${ }^{2}$

Households with two or more persons in $2011^{3}$
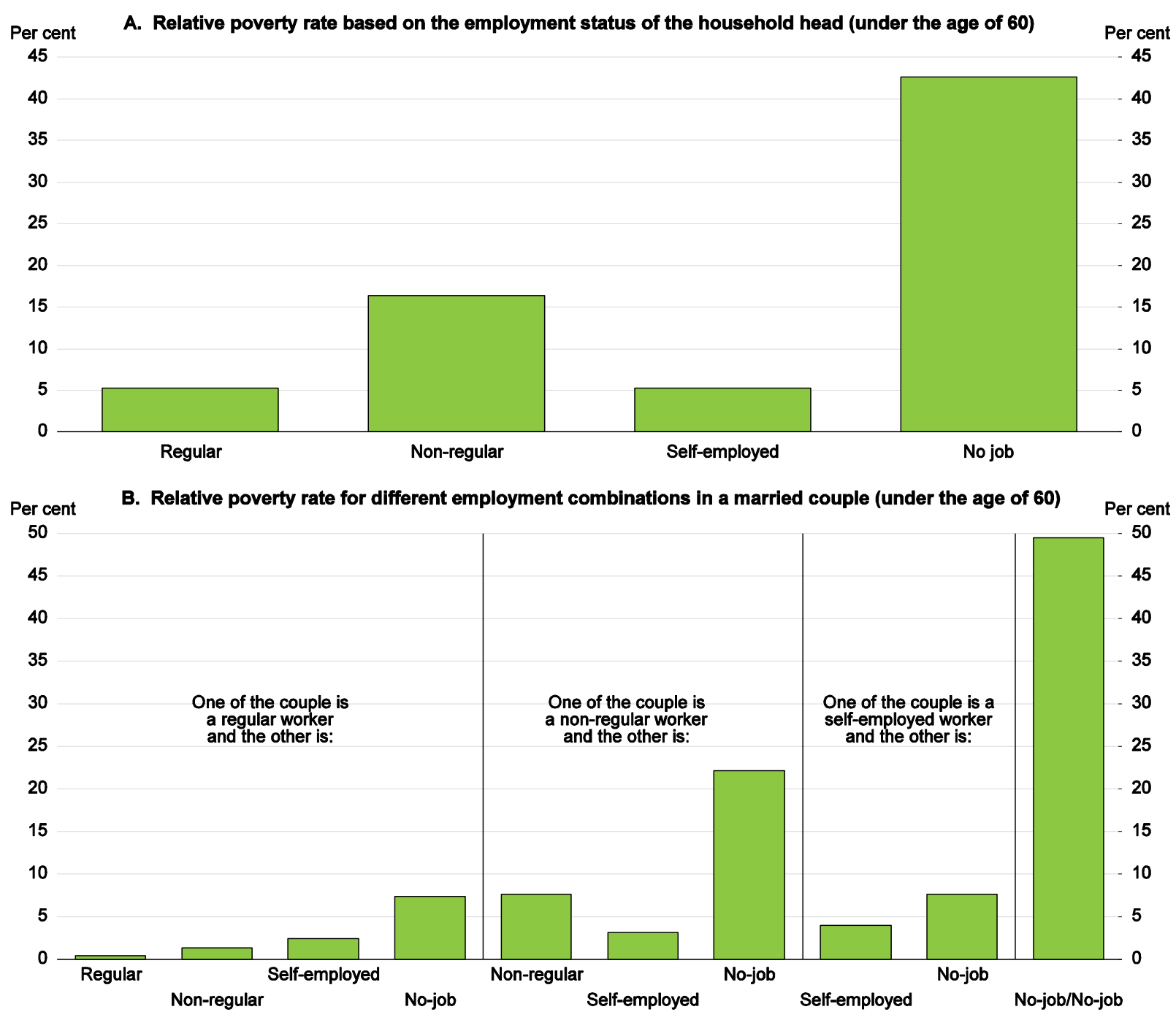

1. Relative poverty is defined as the percentage of the population with an income less than half of the national median.

2. Based on the Korean Labour and Income Panel Survey (KLIPS), an annual household survey since 1998 that consists of about 6000 households (13 000 individuals). Non-regular workers are identified using the official definition of non-regular workers, the same definition used in Strengthening Social Cohesion in Korea (OECD, 2013b). Job status and age category is that of the household head.

3 Income is based on total income, which includes earned income (after tax and social insurance contributions), financial income, real estate income and social benefits.

Source: Korea Labour Institute, Korean Labour and Income Panel Survey (KLIPS); OECD calculations.

The limited mobility between regular and non-regular employment in Korea exacerbates inequality. In Korea, non-regular employment is rarely a stepping stone to regular employment: the probability of moving from temporary to permanent employment over a one-year period was only $11.1 \%$, as against over $50 \%$ in a number of European countries (OECD, 2013b). Temporary and part-time workers in Korea are less likely to move to a regular job during the following year than unemployed people with similar characteristics according to a survey (OECD, 2015b). Moreover, the shift to regular status is often reversed: over a ten-year period, $70 \%$ of workers who shifted from non-regular to regular jobs lost their regular status within four years (Kim and Lee, 2013). The long-term implications of labour market dualism make it even more important to break down dualism. 
Figure 7. Spending on education is much higher in households headed by regular workers

Households with two or more persons in $2011^{1}$
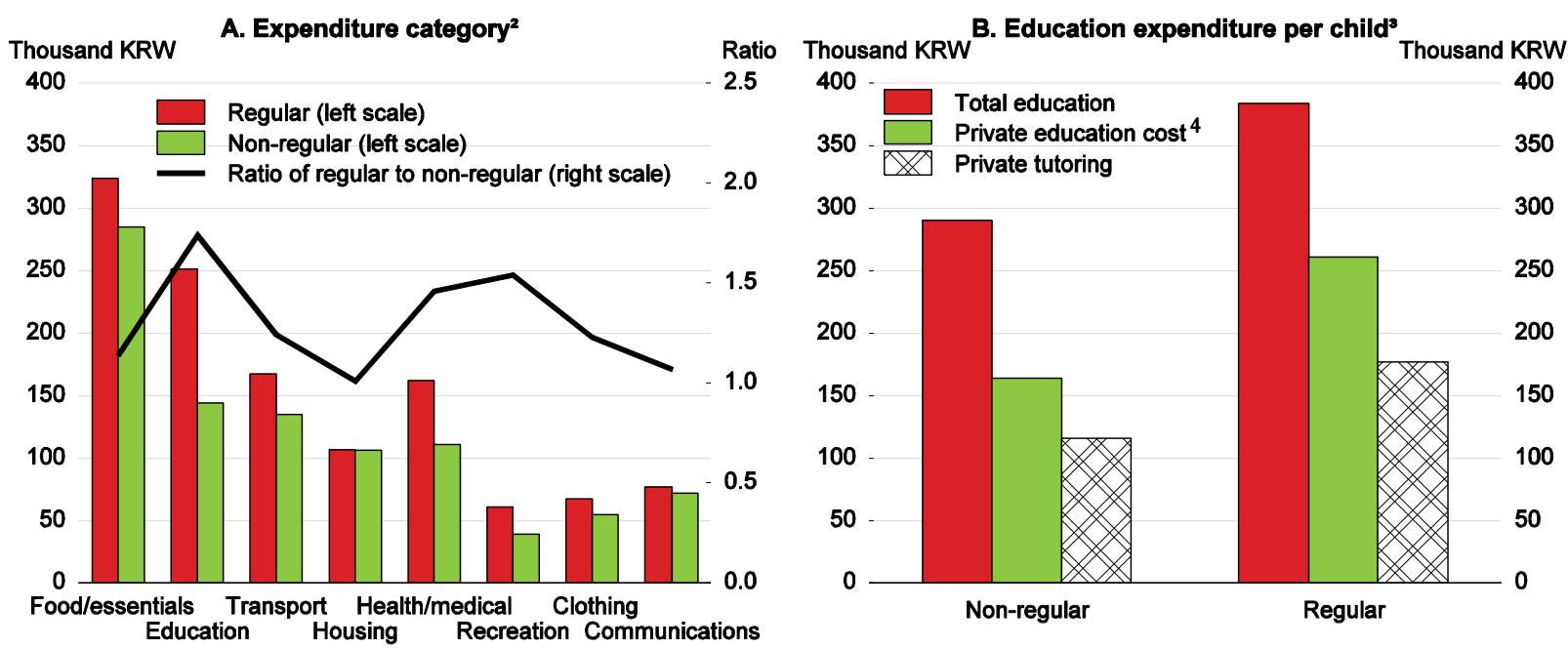

1. Based on the Korean Labour and Income Panel Survey (KLIPS), an annual household survey since 1998 that consists of about 6000 households (13 000 individuals). Non-regular workers are identified using the official definition of non-regular workers, the same definition used in Strengthening Social Cohesion in Korea (OECD, 2013b). Job status and age category is that of the household head.

2. The data are on an equivalised based to take account of the size of the household (household expenditure divided by the square root of the number of persons in the household).

3. Up to age 18.

4. Private education cost includes private tutoring institutions (hagwons), private tutors, and early childhood education and care.

Source: Korea Labour Institute, Korean Labour and Income Panel Survey (KLIPS); OECD calculations.

\section{Policies to break down labour market dualism}

The objective should be to implement the principle of equal pay for equal work by ending the segmentation of the labour market. Korea's emphasis on protecting jobs has failed to deliver employment stability and income security, as a large share of the labour force is in non-regular employment. The government has introduced a number of policies during the past ten years to address this issue (Box 2). Nevertheless, the share of employees in non-regular employment in 2014 was close to the 2003 level of one-third, while the wage gap between regular and non-regular workers has widened.

The 2007 reform that limits fixed-term contracts to two years (with some exceptions) has been counterproductive as it increased job precariousness. Over 2010-13, around one-half of employees on fixed-term contracts who had worked at least 18 months left their firm when their contract expired. The proportion was 66\% at firms with more than 300 employees (2014 OECD Economic Survey of Korea). Meanwhile, less than one-third of workers were converted to regular status, which was the objective of the law. Firms tend to prefer to hire a new non-regular worker rather than convert a current non-regular worker to regular status. The government has proposed that the limit on fixed-term contracts be extended to four years for employees above age 35 . However, this proposal is not accepted by labour unions.

The 2007 reform also outlawed "unreasonable discrimination", in terms of wages and working conditions, against non-regular workers who perform tasks similar to regular workers in the same firm. Korea is exceptional in this regard, as few other OECD countries have laws that explicitly require that temporary workers be paid the same wages as equivalent permanent workers. In practice, however, it is difficult to prove the existence of discriminatory treatment. Moreover, workers are hesitant to file complaints, fearing a negative reaction from management. With only 2529 discrimination cases filed over 2007-12, the law was revised in 2012 to require labour inspectors to encourage firms to correct any 
discrimination, even in the absence of complaints. In 2014, 343 workplaces were inspected and 48 were found to have discriminatory practices. Under the Tripartite Agreement, the government will make the system more effective by awarding punitive damages.

\footnotetext{
Box 2. Policies implemented or proposed to break down labour market dualism

\section{The 2007 reform of the labour law}

After five years of discussion with the social partners, the labour law was reformed in 2007 to:

1. Limit non-regular workers' employment in a firm to a maximum of two years and support their transition to regular status.

2. Prohibit "unreasonable discrimination", in wages and working conditions, between non-regular and regular workers who work in similar jobs in the same firm.

The Comprehensive Non-regular Workers Initiative (September 2011)

This initiative aimed at strengthening the social safety net and enhancing equal treatment for non-regular workers by:

1. Subsidising SME contributions to social insurance systems to expand the coverage of their employees, including non-regular workers.

2. Broadening the coverage of social insurance to include special types of employment.

3. Better enforcing the minimum wage.

4. Upgrading inspection of labour conditions to promote balanced treatment of regular and non-regular workers.

5. Expanding vocational training opportunities for non-regular workers and promoting their shift to regular jobs.
}

Comprehensive Measures for Non-regular Workers (December 2014)

The government proposal, which was launched when the tripartite negotiations stalled, included:

1. Clarifying the rules and procedures for terminating the labour contracts of regular workers, based on a fair assessment and clear criteria.

2. Paying SMEs that convert non-regular workers to regular status a one-year subsidy equal to half of the wage increase resulting from the conversion.

3. Allowing fixed-term employees above age 35 to extend contracts to four years rather than being restricted to the two-year limit under the current law.

4. Permitting labour unions to request the correction of discriminatory treatment against non-regular workers.

5. Allowing non-regular workers to join decision-making bodies, such as the ESDC.

6. Promoting the shift of non-regular workers in the government to regular status.

The Tripartite Agreement (September 2015)

The Agreement, which is outlined in Box 1, contains a number of measures targeted at labour market dualism:

1. Company-based welfare funds will be used to assist non-regular workers; employees in the top $10 \%$ income bracket will voluntarily refrain from seeking wage increases to provide more resources for non-regular workers.

2. The tripartite partners shall prohibit unreasonable discrimination against non-regular workers and "strive to not overuse non-regular workers simply for the purpose of reducing labour costs".

3. The government will convert more non-regular workers in permanent roles in the public sector to regular status than they had originally planned (about a quarter of its non-regular employees) over 2013-15.

4. The government will make the discrimination correction system more effective by expanding the coverage of correction orders and awarding punitive damages.

5. Firms and workers will take action to improve the job security and working conditions of non-regular workers.

6. Firms and workers shall create a culture of regular and direct employment, and work together to set up reasonable principles to guarantee job security for incumbent employees and employ more young workers.

7. The tripartite partners will clarify the standards and procedures for employment contract termination.

8. When employment adjustments are required for managerial reasons, firms shall attempt to minimise workforce reductions by adjusting wages and working hours, relocating employees, suspending business temporarily, or giving employees leaves of absence or vocational training.

9. The tripartite partners shall ensure that the measures that employers are required to take to avoid dismissals for managerial reasons are specifically spelled out in the Labour Standards Act.

The measures limiting fixed-term contracts and prohibiting discrimination have had limited effect on dualism. Breaking down dualism instead requires reducing the incentives that encourage firms to hire non- 
regular workers, notably to enhance employment flexibility and reduce labour costs. While wages are set by management and workers, the government can reduce the gap in labour costs by increasing non-regular workers' coverage by social insurance. By law, the three major social insurance schemes -- the National Pension Scheme (NPS), National Health Insurance (NHI) and the Employment Insurance System (EIS) should cover nearly all private-sector workers. While coverage of regular workers is nearly universal, the coverage of non-regular workers by the three major schemes averaged 54.1\% in 2015 (Table 4). The lower EIS coverage of non-regular workers $(63.0 \%)$ is particularly problematic, given their precarious employment. Hiring a non-regular worker who is not covered by any of the three schemes cuts a firm's labour cost by $8-9 \%$ compared to a regular worker who is covered.

In 2012, the government introduced a subsidy for social insurance contributions. It now covers half of the contribution (employers and employees combined) for workers earning less than 1.4 million KRW per month (about USD 1 223) in workplaces with fewer than ten employees. The number of subsidised workplaces has reached 0.7 million (around one-fifth of firms with less than ten employees). However, the subsidy may discourage firms from expanding and surpassing the limit of ten employees. It is essential to increase compliance with social insurance systems to weaken incentives to hire non-regular workers and enhance the welfare of such workers. At present, the NHI is responsible for collecting all social insurance contributions. Giving the National Tax Service a larger role in supporting the collection of contributions and stricter enforcement of penalties for non-compliance could increase coverage for all workers.

In addition, workers with less than one year of tenure are not entitled to the retirement allowance, which mandates one month of salary per year of work, giving firms an additional incentive to hire workers on contracts of less than one year. Consequently, less than half of non-regular workers receive the retirement allowance (Table 4). Moreover, less than a quarter receive bonus payments, which account for around a quarter of annual employee earnings.

Table 4. Non-regular workers receive less social insurance and company-based benefits

Percentage of employed persons by status in 2015

\begin{tabular}{l|cccc|cc|}
\cline { 2 - 6 } & $\begin{array}{c}\text { National } \\
\text { Pension } \\
\text { Scheme }\end{array}$ & $\begin{array}{c}\text { National } \\
\text { Health } \\
\text { Insurance }\end{array}$ & $\begin{array}{c}\text { Employment } \\
\text { Insurance } \\
\text { System }\end{array}$ & $\begin{array}{c}\text { Average for } \\
\text { social } \\
\text { insurance }\end{array}$ & $\begin{array}{c}\text { Retirement } \\
\text { allowance }^{2}\end{array}$ & $\begin{array}{c}\text { Bonus } \\
\text { payments }\end{array}$ \\
\hline Total & 87.6 & 87.5 & 88.5 & 87.9 & 81.2 & 58.1 \\
Regular & 97.6 & 97.8 & 95.4 & 96.9 & 93.1 & 69.4 \\
Non-regular & 48.2 & 51.2 & 63.0 & 54.1 & 45.1 & 23.8 \\
of which: & & & & & & \\
Part-time & 48.5 & 50.4 & 58.4 & 52.4 & 33.3 & 16.0 \\
Atypical & 30.6 & 35.1 & 58.6 & 41.4 & 33.6 & 12.7 \\
\hline
\end{tabular}

1. The simple average for the National Pension Scheme, National Health Insurance and the Employment Insurance System.

2. The law requires payment of at least one month of wages for each year worked for departing employees.

3. Bonus payments, which are paid two or three times a year, amount to around a quarter of employee compensation.

Source: Ministry of Employment and Labour, Survey on Labour Conditions by Employment Type 2015.

The Tripartite Agreement stated that the minimum wage will be gradually increased and the government will promote compliance by tightening sanctions on violations and expanding labour inspections to prevent and detect such violations. Over the past decade, Korea's minimum wage has risen at a $7 \%$ annual average rate, far outstripping overall wage gains of less than $3 \%$ per year. By 2015 , the minimum wage was nearly half of the median wage, matching the OECD average (Figure 8). In 2016, the minimum wage will be increased by another $8.1 \%$, the largest increase since 2008 , in part to boost domestic demand. The government expects that the 2016 hike will affect the pay of $18 \%$ of employees. 
Figure 8. The minimum wage relative to the median wage in Korea is near the OECD average

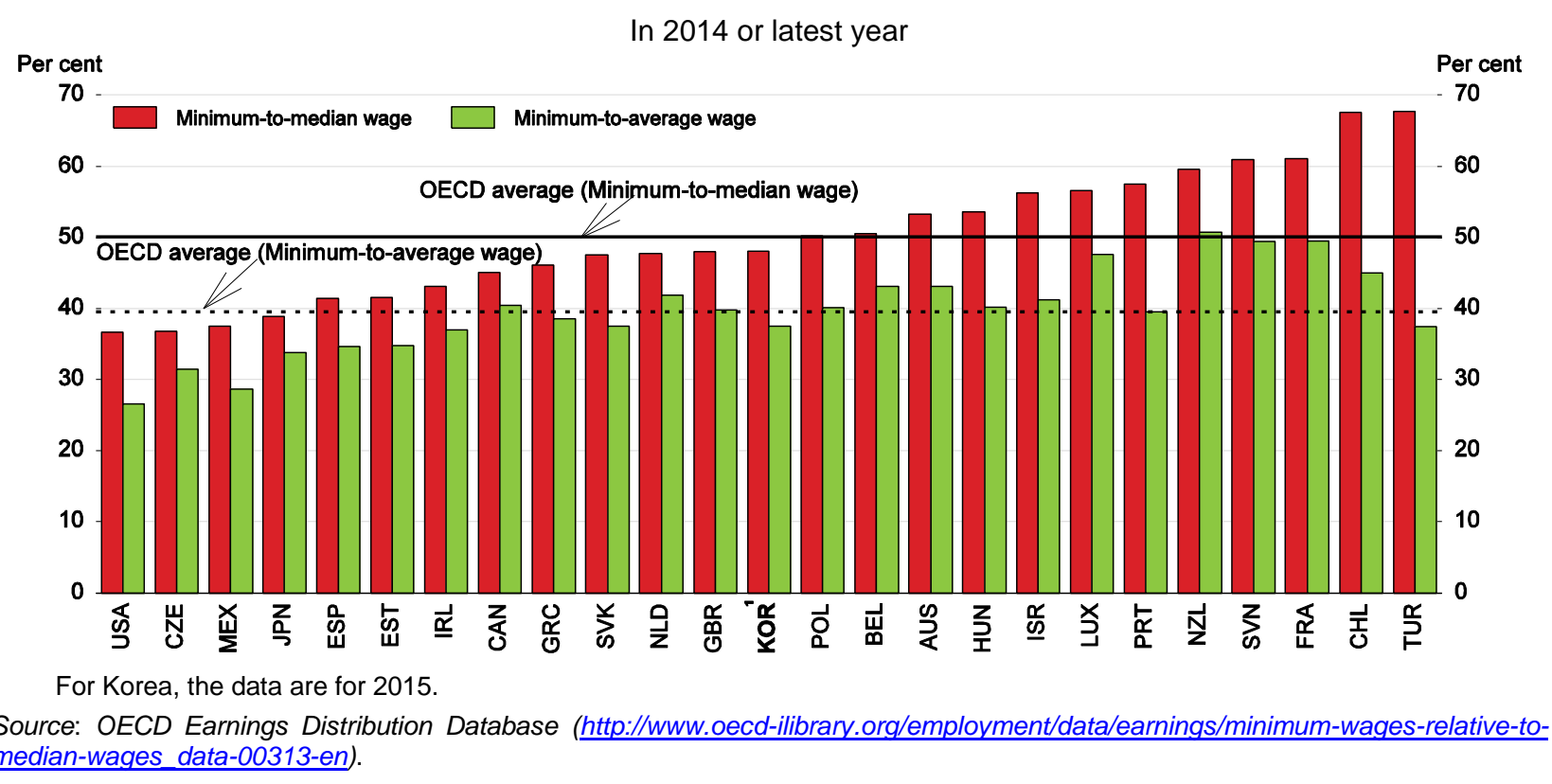

Korea could benefit from a moderate increase in its minimum wage, given its wide wage dispersion and high relative poverty rate. A household with children and one worker earning the minimum wage would have an income below the relative poverty line. Raising the minimum wage would boost the income of some non-regular workers and narrow the distribution of labour income. However, if set too high, the minimum wage could reduce employment, which would dampen its inequality-reducing effect. In Korea, $10 \%$ of workers are paid the minimum wage or less (Yoo, 2013). Around $70 \%$ of such workers were employed in small firms with less than ten workers and around one-third were in households in relative poverty. Raising the minimum wage too fast could undermine employment in micro firms and increase poverty. It is also important to improve compliance with the Minimum Wage Act, given weak enforcement and a lack of penalties for violations. Of the nearly 20000 cases in 2011 alleging violations, only 11 resulted in a legal ruling against the employer and most of these only requested "corrective measures" (OECD, 2013b). The government has introduced a bill aiming at better monitoring and enforcement of compliance with the minimum wage.

Breaking down dualism also requires addressing employment protection for regular workers, which has prompted firms to hire non-regular workers to enhance employment flexibility (2014 OECD Economic Survey of Korea). Regular workers receive high employment protection as a result of labour laws, court decisions, business practices, social customs and labour unions (Koh et al., 2010). Dismissals for economic reasons are strongly regulated, with many procedural inconveniences for firms: consultations with workers, implementation of measures to avoid or minimise layoffs, and strict selection criteria for selecting the employees to be dismissed. In addition, there must be "urgent managerial reasons", a criterion that is not well-defined and difficult to prove in court. Courts take into account the company's financial situation, market conditions and competitiveness. Therefore, layoff costs are difficult to predict for employers, but they can be very high due to long and complex court rulings. Furthermore, dismissals for incompetence or negligence of duty are likely to be rejected by courts. In short, dismissal costs are high (Lee, 2015).

The cost, uncertainty and time necessary to meet the conditions necessary for laying off regular workers increase incentives for firms to hire non-regular workers. International evidence suggests that temporary jobs are a common response by firms to high costs of reducing permanent jobs (Kahn, 2010). The Tripartite Agreement acknowledged the importance of reform, stating that it will "clarify the standards and procedures for terminating employment contracts" (Box 2). Relaxing employment protection would 
boost productivity and output growth by enabling innovative firms to attract the human resources necessary to commercialise new ideas and encouraging firm-based training as reliance on temporary workers declines (2014 OECD Economic Survey of Korea). However, relaxing employment protection is strongly opposed by regular workers. To break down dualism, Korea needs a comprehensive strategy of relaxing employment protection for regular workers and making it more transparent, raising the minimum wage and increasing social insurance coverage and upgrading training for non-regular workers. One option would be to introduce reduced employment protection for new employees, while current employees retain their protection under a grandfather clause. This approach appears to have been successful in Italy and Spain. However, such an approach in Korea would further penalise youth, who already face difficult labour market conditions. Measures to expand protection by the social safety net, as stated in the Tripartite Agreement, may facilitate a significant reduction in employment protection for regular workers.

\section{Strengthening the social safety net}

Korea needs to shift from protecting jobs to protecting individuals. The redistributive impact of the tax and transfer system on income inequality and relative poverty is one of the weakest in the OECD (Figure 9), although it has increased in recent years. The redistributive impact is limited by the low level of public spending at $10.6 \%$ of GDP in 2014, less than half of the $22 \%$ OECD average, while the tax and social security contribution burden, at $33 \%$ of GDP, is well below the OECD average of $42 \%$. Moreover, the progressivity of the tax and benefit system is limited (2014 OECD Economic Survey of Korea). Korea's high level of wage inequality and relative poverty makes it essential to make the tax and transfer system more effective in redistribution. OECD research suggests that redistribution does not necessarily harm output growth (OECD, 2015b). An international survey found that the Korean population ranked second among 14 OECD countries in its support for income redistribution (World Values Survey, 2015).

Employment insurance, the in-work earned income tax credit (EITC) and the Basic Livelihood Security Programme (BLSP) are the major social welfare programmes for the working-age population. Unemployment benefits are relatively low at $50 \%$ of the person's daily wage before losing their job, compared to the OECD average of nearly $70 \%$. In addition, the duration is relatively short, limited to 180 to 240 days depending on age. In contrast, the average duration in the OECD area is 2.3 years. The key concern with Korea's employment insurance, though, is the number of people ineligible for unemployment benefits as they are not covered. It is estimated that more than one-third of non-regular workers are not covered by employment insurance.

The EITC was initially introduced in 2008 for employed persons with children and expanded to childless couples and some self-employed workers in 2012 and to single people in 2014. The benefit level in 2014 for households with children was 6-8\% of the average wage, which is comparable to New Zealand, although below US and UK levels. However, coverage was limited to $8 \%$ of households in 2015, in part due to eligibility criteria, such as the limit on the value of housing owned by recipients to 140 million KRW (USD 122 320) (OECD, 2015f). Spending on the EITC was only 0.1\% of GDP in 2015. Further expanding the coverage, while extending the income level at which EITC payments are phased out, currently set at $33 \%$ to $68 \%$ of the average wage, would help low-income families (OECD, 2013b).

The BLSP provides a cash benefit and in-kind support, for example for health care and education, to eligible persons in absolute poverty. The maximum support was equivalent to $26 \%$ of the average income in 2013, putting it in the bottom third of OECD countries (Figure 10). BLSP support has been limited to about 3\% of the population by strict eligibility criteria on asset ownership and the "family support obligation rule". In 2015, the government shifted its focus from absolute poverty to relative poverty and set different income thresholds for receiving the cash benefit (below 29\% of the national median income) and for in-kind support, such as medical services (40\%), housing (43\%) and education benefits (50\%). In addition, eligibility criteria were relaxed. To further reduce in-work poverty and enhance incentives to 
work, the government allowed BLSP recipients to receive the EITC beginning in 2015. Further relaxing eligibility criteria would make the BLSP more effective in reducing poverty.

Figure 9. The impact of taxes and transfers on income inequality and poverty is weak in Korea Working-age population in 2013 or latest year
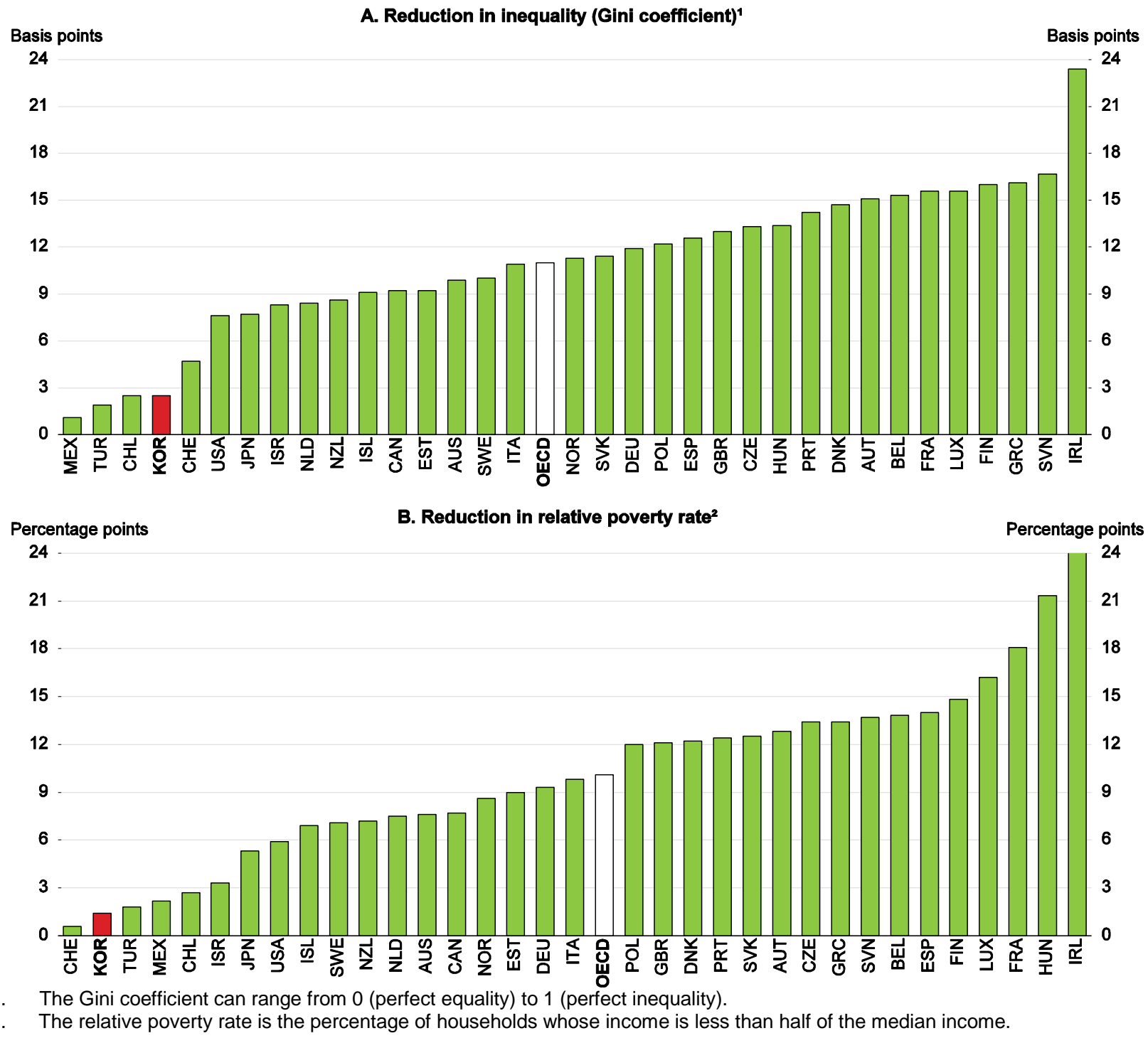

Source: OECD Income Distribution and Poverty Database (http://www.oecd.org/els/soc/income-distribution-database.htm).

\section{Expanding employment opportunities for women}

The employment rate of women was the tenth lowest in the OECD in 2014. Moreover, it was 21 percentage points below the employment rate of Korean men in 2014 (Table 1), the fourth-largest gap in the OECD area. Although the employment rate for women matches that for men until age 30, it falls as women withdraw from the labour force following marriage and childbirth. Many women eventually return to the labour market, resulting in an M-shaped employment rate across age cohorts (Figure 11). The female employment rate is thus limited by the large share of women in the 30-40 age group who withdraw, at least temporarily, from the labour force. 
Figure 10. The income level provided by cash minimum-income benefits in Korea is low

Net income value of benefits to a single person as a percentage of average income in 2013

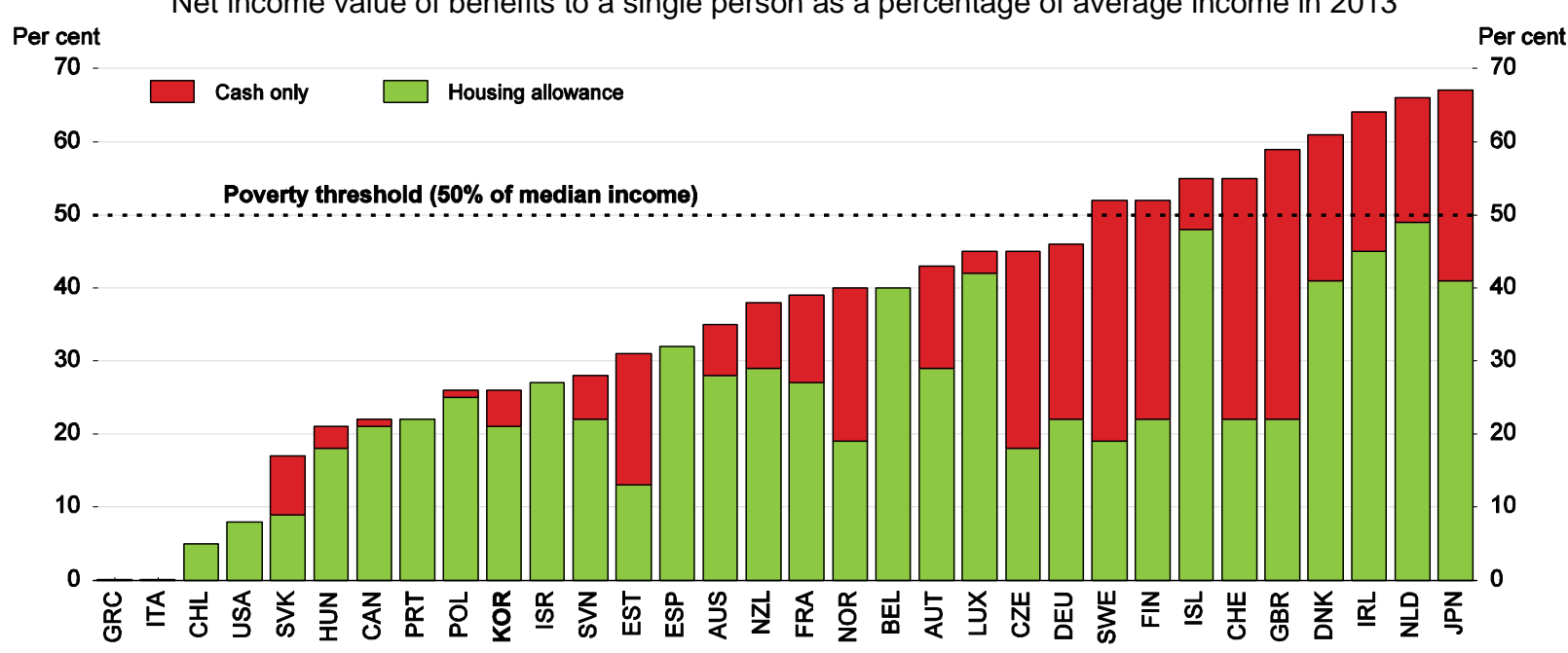

Source: OECD Tax and Benefit Models (http://www.oecd.org/els/benefits-and-wages-statistics.htm).

\section{Factors that influence women's decision to leave the labour force}

Women's decision to leave the labour force following marriage and childbirth is influenced by a number of factors, including: $i$ ) maternity and parental leave; $i i)$ the availability of high-quality childcare; and iii) working time and the role of men in family responsibilities. Taxation of earned income is personal, rather than family based, and so does not penalise the second earner.

Figure 11. Korea's female employment rate still had an M-shaped pattern in 2014

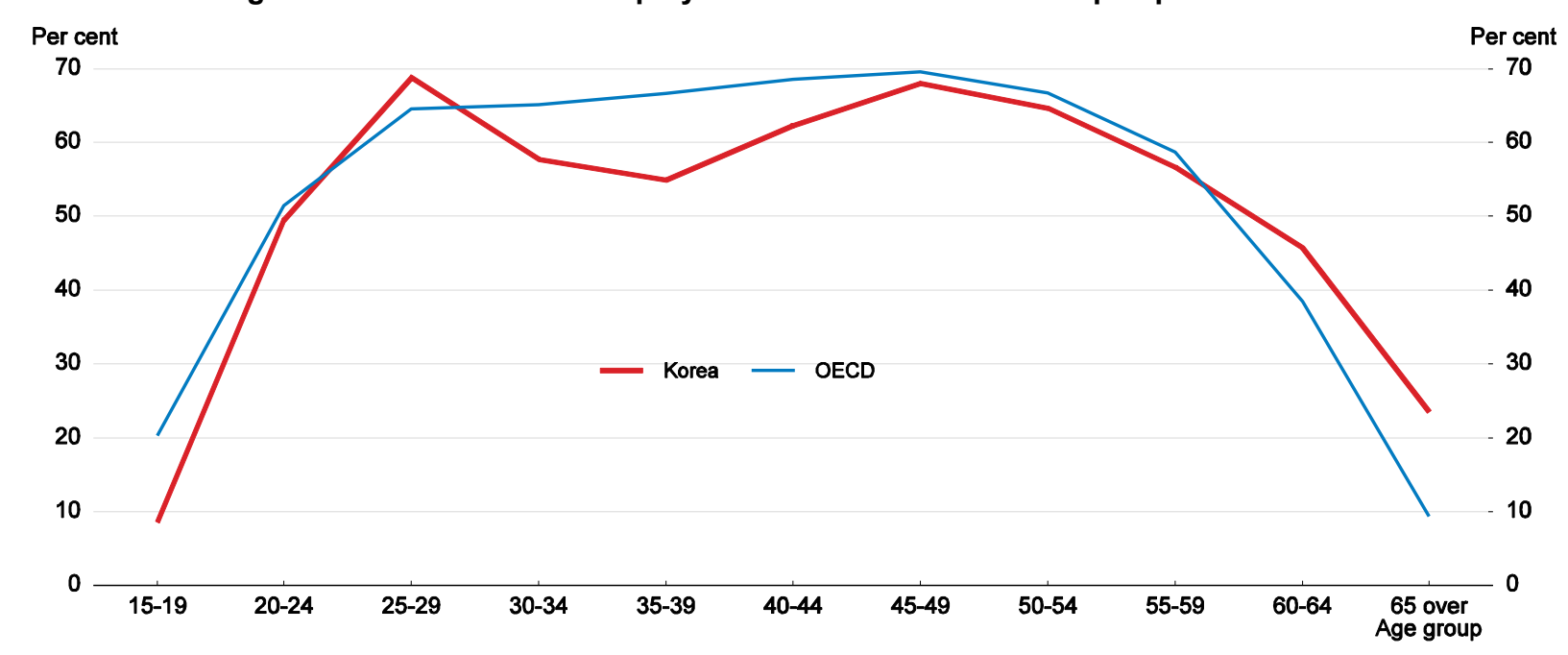

Source: Korea National Statistical Office: OECD Labour Market Statistics Database (http://www.oecd.org/employment/emp/employmentdatabase-employment.htm).

Improving the maternity and parental leave systems

The exodus of mothers out of the labour market suggests that the maternity and parental leave systems are not fully achieving their objectives. Since 2001, all women have been guaranteed 90 days of paid 
maternity leave. To ease the burden on firms and to limit any negative effect on the hiring of women, the EIS pays one month of the leave (all three months in the case of SMEs) for private-sector employees who have contributed to the EIS for at least 180 days. The number of women in the private sector taking maternity leave nearly doubled between 2006 and 2012 before declining somewhat (Figure 12). The number of maternity-leave takers rose from 11\% of the number of births in 2006 to $20 \%$ in 2014 (Panel B).

Figure 12. Trends in maternity and parental leave ${ }^{1}$

\section{A. Number of persons taklng maternlty and parental leave}

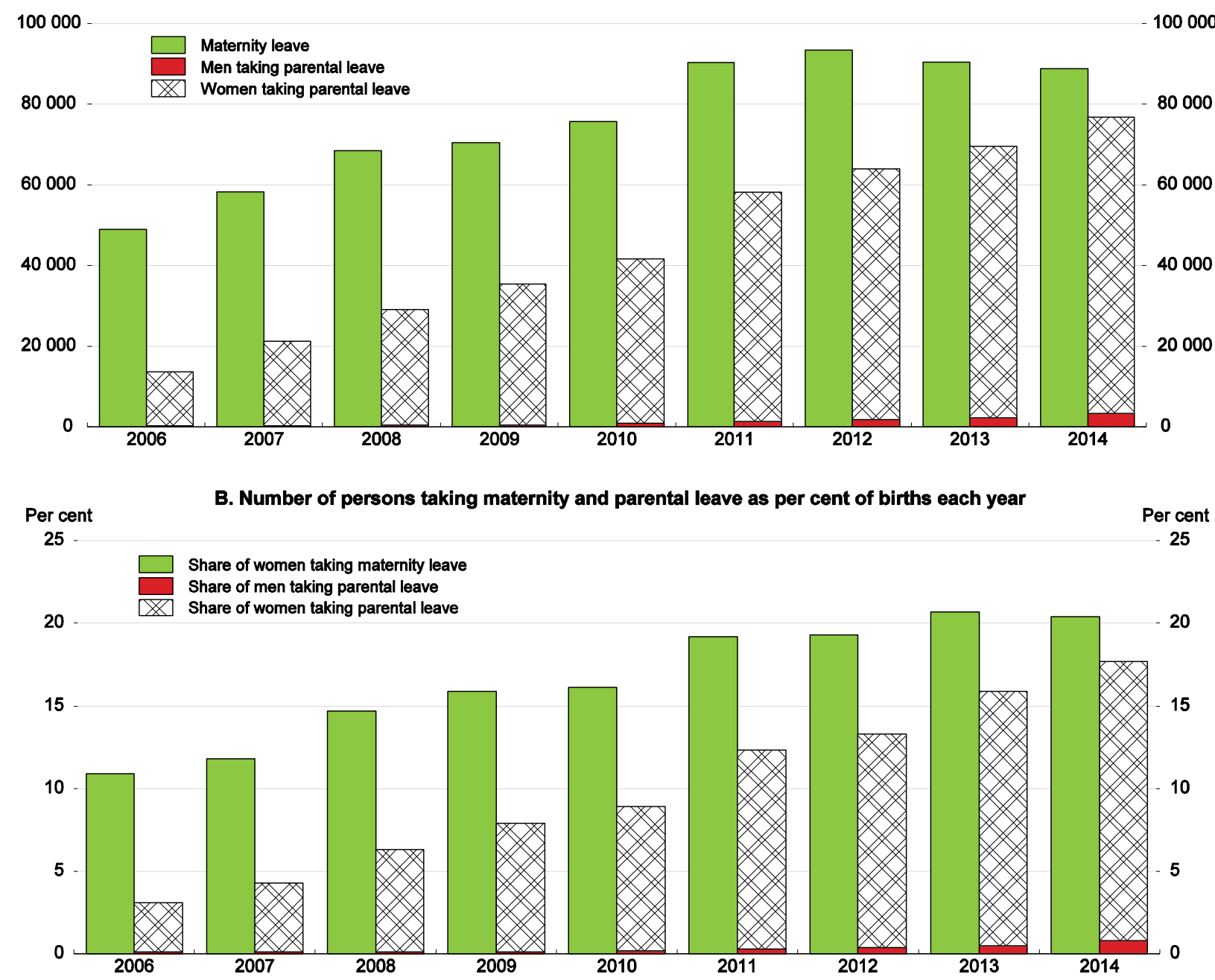

1. Data provided by the Employment Insurance System, which excludes public-sector employees.

Source: Yoon (2014).

The small share of new mothers taking maternity leave reflects their low labour force participation. Only $35.6 \%$ of the women who gave birth in 2014 were covered by the National Health Insurance as employees, rather than dependents (Table 5). In contrast, the overall participation rate for women in the 2534 age group was much higher at $62 \%$. The large gap indicates that a substantial share of women leave the labour force before having a baby, despite the advantages of remaining employed and qualifying for three months of paid leave. The gap reflects several factors. First, management may encourage women's departure so as to avoid paying maternity leave (SBS News, 2014). Second, some firms tend to push the workload of mothers absent on maternity leave onto other employees rather than hiring more workers, thus making some women reluctant to take maternity leave (SERI, 2010). 
Table 5. Maternity leave and employment status

\begin{tabular}{|c|c|c|c|}
\hline \multicolumn{4}{|c|}{ A. Employment status of women at time of giving birth (per cent) ${ }^{1}$} \\
\hline & 2012 & 2013 & 2014 \\
\hline Employed & 33.6 & 34.5 & 35.6 \\
\hline Employees & 29.6 & 30.6 & 31.6 \\
\hline Public sector & 6.5 & 6.7 & 6.0 \\
\hline Private sector & 23.1 & 23.9 & 25.6 \\
\hline Self-employed & 4.0 & 3.9 & 4.0 \\
\hline Not in labour force & 66.4 & 65.5 & 64.4 \\
\hline \multicolumn{4}{|c|}{ B. Share of new mothers taking maternity leave (per cent) } \\
\hline & 2012 & 2013 & 2014 \\
\hline Public-sector employees ${ }^{2}$ & 100.0 & 100.0 & 100.0 \\
\hline Private-sector employees & 83.3 & 86.9 & 79.6 \\
\hline All women who work ${ }^{3}$ & 76.6 & 79.6 & 74.0 \\
\hline All new mothers & 25.7 & 27.5 & 26.3 \\
\hline
\end{tabular}

1. This is based on the National Health Insurance, which reports whether the mother is covered as an employee, self-employed or under the name of her husband or other family member (which means that they are not employed).

2. Assuming all women employed in the public sector at the time of giving birth take maternity leave.

3. Public and private-sector employees, plus self-employed.

Source: Ministry of Health and Welfare; National Health Insurance.

In addition, the share of new mothers taking maternity leave (26.3\% in 2014) is well below the share of new mothers who are employed at the time of giving birth (35.6\%) (Table 5). Part of the difference is due to self-employed women, who account for $4 \%$ of new mothers and who are not eligible for maternity leave. The share of women taking maternity leave is further reduced by gaps in coverage, notably among non-regular workers and employees at SMEs, even if they are covered by the EIS. Indeed, one-fifth of new mothers employed in private firms do not receive maternity leave (Table 5, Panel B). Some women leave their firm soon after giving birth, thereby losing their entitlement to maternity leave. In $2011,10.5 \%$ of new mothers covered by workplace-based health insurance at the time of giving birth were no longer covered three months later (Yoon, 2014). Moreover, some women, particularly those employed as nonregular workers, continue to work rather than take maternity leave due to job security concerns.

Ensuring the right of all new mothers to take maternity leave is thus a priority. In 2015 , the government launched workplace guidance and inspection measures to improve compliance (MOEL, 2015). Effectively implementing the new monitoring and enforcement measures is essential. In addition, breaking down labour market dualism is a priority, given that the take-up of maternity leave is lower among nonregular workers.

Parental leave has a positive impact on female labour participation (OECD, 2011). In Korea, parents have had the right to paid parental leave since 2001 and the system has been revised several times to encourage its use. Since 2008, parents in two-income households are each allowed up to one year of leave or reduced working time (15 to 30 hours per week) to care for children up to the age of eight. The one-year leave for fathers is the longest in the OECD. The benefit is set at $40 \%$ of the parent's basic wage up to a ceiling of 1 million KRW (less than one-third of the average wage) if the parent has been enrolled in the EIS for at least 180 days. An employer cannot refuse a request for parental leave from a worker who has been at the firm for at least one year.

The number of parents taking parental leave rose more than five-fold over 2006-14 and is approaching the level of maternity leave (Figure 12). As with maternity leave, parental leave is concentrated among regular workers in large firms, reflecting weaker coverage by the EIS and concerns about job security among employees at SMEs and non-regular workers. The take-up of parental leave is limited by the small 
number of fathers using it. While the number rose from 230 in 2006 to 3400 in 2014, men accounted for only $4.5 \%$ of parents taking the leave in 2014. In contrast, fathers took $25.5 \%$ of parental leave days in Sweden and $28.5 \%$ in Iceland in 2013. Moreover, the average length of leave taken by fathers in Korea is 8.3 months, compared to ten months for mothers.

Parental leave by fathers is one of the most important measures to reduce the gender wage gap and alleviate gender discrimination in the labour market, as it facilitates women's return to employment (Cools et al., 2011). Fathers who take parental leave are more likely to engage in childcare activities. In addition, it has a positive impact on child development (Huerta et al., 2013). The small number of Korean men taking parental leave reflects concern that it will hurt their career prospects, which suggests that women's career prospects are being damaged. Another obstacle is the substantial income loss during the leave. Given the large gender wage gap in Korea (see below), it is financially advantageous in most cases that the mother, rather than the father, take the parental leave. Increasing financial support during parental leave would encourage more parents, particularly fathers, to take it. The government should also ensure that employers respect the legal right of workers to take parental leave.

In 2014, the benefit for reduced working hours during the childcare period was raised from $40 \%$ to $60 \%$ of the base wage (adjusted by the reduction in working time) and the government proposed that parents be allowed to choose up to two years of reduced working hours instead of one year of parental leave. In October 2014, the government started "Father's Month": if both parents take childcare leave successively, the childcare leave benefit for the second parent is raised to $100 \%$ of their ordinary wage (up to 1.5 million KRW) for the first month. These steps may encourage more fathers to take parental leave.

\section{The availability of high-quality childcare}

Korea has sharply increased public spending on early childhood education and care (ECEC) during the past decade. Central government outlays on childcare and pre-primary education each rose from less than $0.1 \%$ of GDP in 2006 to $0.3 \%$ in 2013 (Figure 13). Nevertheless, spending on pre-primary education per child in Korea in 2012 was 30\% below the OECD average. The decision in 2013 to provide 12 hours per day of free childcare for all children up to age five, regardless of the employment status of the mother and family income, may further push up government outlays on childcare.

Figure 13. Central government expenditures on ECEC have risen sharply

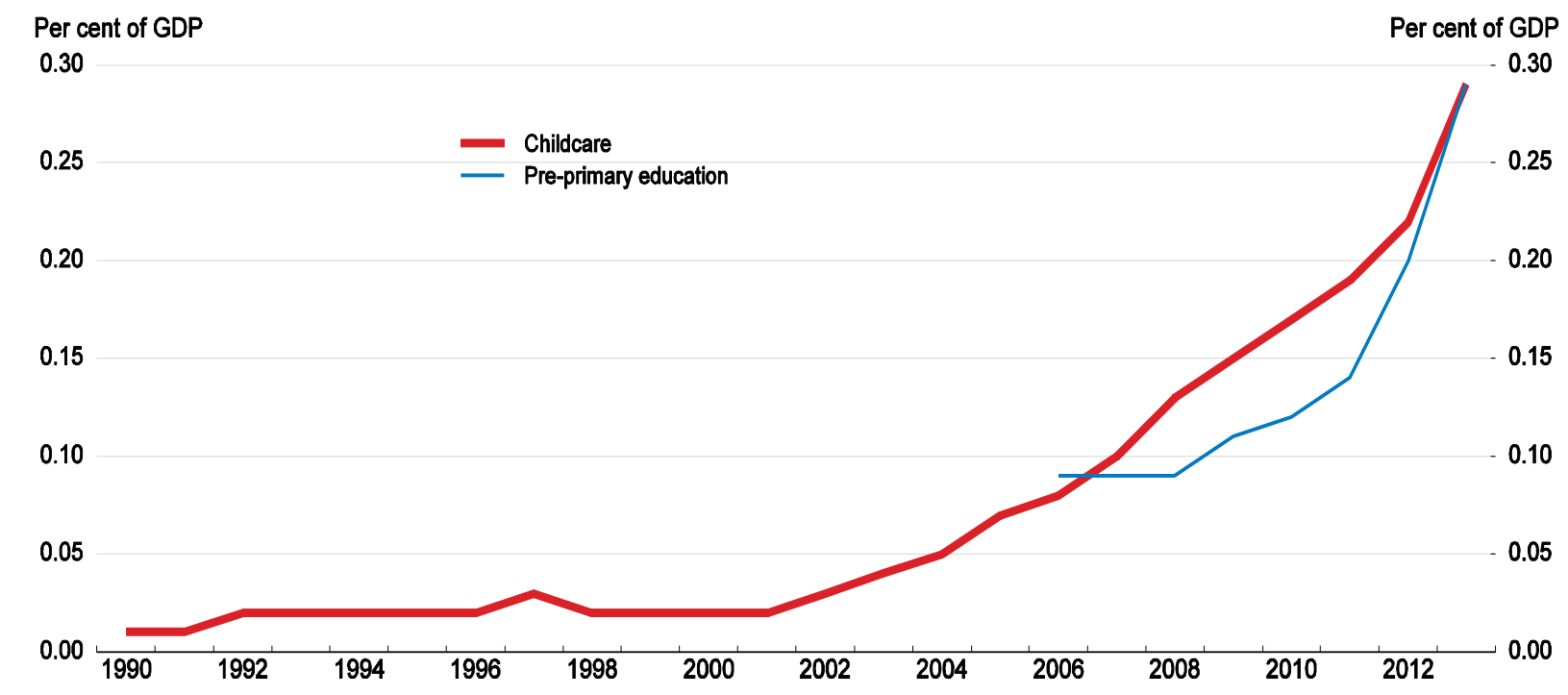


The share of children aged 0-2 enrolled in childcare rose from $11 \%$ in 2006 to $34 \%$ in 2013, the largest increase in the OECD during that period, putting it above the OECD average of 33\% (Figure 14). However, the share of mothers of children aged 0-2 in Korea who were employed was 35\% in 2013, far below the OECD average of 51\% (Panel B), suggesting that the rise in childcare enrolment is not fully reflected in female employment. With increasing government support, the demand for childcare has outstripped supply. Ironically, the guarantee of 12 hours a day of free childcare since 2013 in Korea has not resolved childcare shortages for mothers who want to work. Instead, it has resulted in discrimination against working mothers by private childcare centres, which prefer the children of non-working mothers, who tend to pick up their children earlier than employed mothers, reflecting long working hours in Korea.

Figure 14. Childcare enrolment increased sharply in Korea but the employment rate of mothers remains low

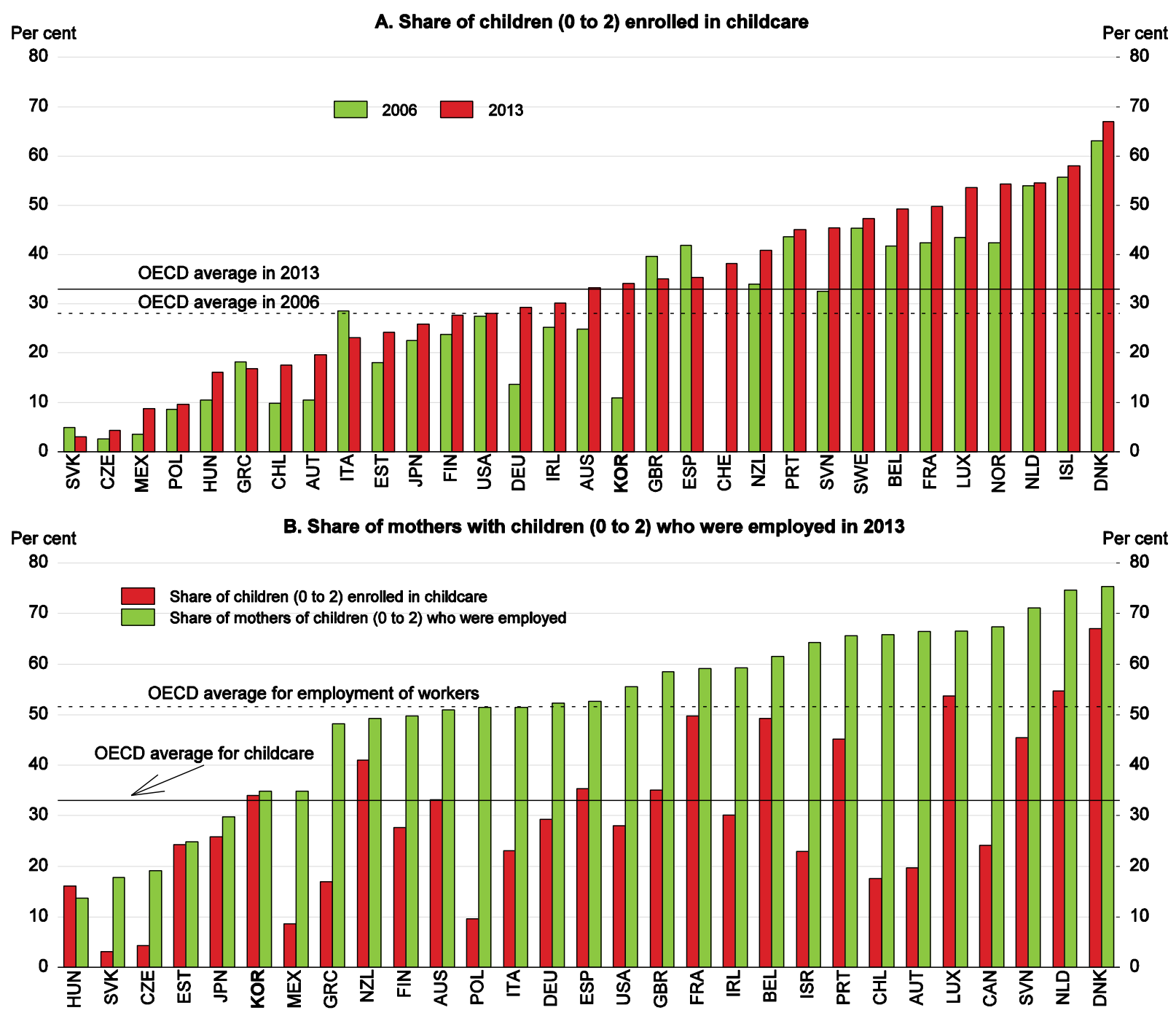

Source: OECD Korea Policy Centre; KIHASA Family Database.

The provision of 12 hours per day of free childcare for all children up to age five, regardless of the employment status of the mother and family income was exceptionally generous. In France, for example, employed women with children aged 0-2 have a right to up to 40 hours of childcare a week, but pay a fee that varies with income. Given the high cost of universal childcare, countries tend to limit the age groups covered (for example, 3-4 in the United Kingdom, 3-5 in France, Israel, Mexico and Portugal) and the hours per day (for example, 3-5 hours in France, Israel, Mexico, Portugal and the United Kingdom) 
(OECD, 2013b). Korea's 2016 budget introduced some changes. The current "full-day support" (12 hours) of free childcare is limited to families that meet at least one criterion: have at least two earners or two unemployed parents, more than one child, a single parent, a mother who is pregnant, or a parent who is disabled. Around $80 \%$ of the budget will be used for full-day support for qualifying families. The remaining $20 \%$ will be used to provide six hours per day of free childcare plus 15 additional hours per month for parents not meeting one of these criteria. The government has also given working mothers priority in enrolling children in childcare to ensure that they have access to childcare.

In addition to discrimination against working mothers, parents face a shortage of high-quality ECEC. Parents need to trust the quality of care before sending their children to childcare or pre-primary education. With waiting lists for public ECEC, the number of private childcare centres increased by an average of 2 300 annually during the past five years to meet rising demand. Local governments, which licence new childcare centres, set standards for entering the market. Entry permission also depends on market conditions. If the childcare occupancy rate falls below a certain level, the local government can prevent the entry of new childcare providers to prevent excessive competition. However, entry barriers tend to weaken the competitive pressure that would otherwise force low-quality providers to exit the market. Studies show that areas with entry restrictions pay low wages to childcare staff and thus have less qualified personnel, which reduces quality (Yun et al., 2014). In addition, private childcare centres are subject to a price ceiling, which was set at $270000 \mathrm{KRW}$ (around USD 235) per month in 2012, thus limiting the quality of service. Finally, the accreditation system operated by the central government is voluntary. In November 2015, $77.8 \%$ of childcare centres had received accreditation.

The quality of public childcare is higher than private institutions, reflecting the qualifications of their teachers. For example, in public childcare centres, $35.3 \%$ of the teachers have at least a university degree, nearly double the share in private centres (Table 6). The gap is also evident for pre-primary education: $85.3 \%$ of the teachers in public institutions have a university degree compared to only $39.4 \%$ in private institutions.

Table 6. Teacher qualifications for ECEC in 2012

Educational attainment of teachers

\begin{tabular}{l|lccc}
\hline & $\begin{array}{c}\text { Institution } \\
\text { type }\end{array}$ & High school & $\begin{array}{c}\text { Some } \\
\text { college }\end{array}$ & $\begin{array}{c}\text { Four-year } \\
\text { degree or } \\
\text { higher }\end{array}$ \\
\hline \multirow{3}{*}{ Childcare } & State/public & 6.0 & 58.7 & 35.3 \\
& Private & 20.1 & 61.0 & 18.9 \\
& Home-based & 29.8 & 51.4 & 18.7 \\
\hline \multirow{2}{*}{ Pre-school } & State/public & 0.1 & 14.6 & 85.3 \\
& Private & 0.0 & 60.5 & 39.4 \\
\hline
\end{tabular}

Source: Yun et al. (2014).

A number of reforms are needed to improve ECEC in Korea and facilitate female employment. First, the government should upgrade accreditation standards and make them mandatory for ECEC institutions. Second, the quality of private ECEC institutions should be improved by strengthening qualification standards for ECEC teachers and raising the pay and benefits of those in private ECEC institutions. Third, fee ceilings on private childcare and entry barriers should be relaxed to improve quality. In the longer run, gradually integrating childcare and pre-primary education would improve quality, while reducing costs (2014 OECD Economic Survey of Korea). Building on the common curriculum, the next step is to harmonise regulations between kindergartens and childcare for children aged 3-5. 


\section{Work-life balance and working time}

The hard-driving corporate culture that discourages men from taking parental leave also results in long working hours for both men and women (Figure 15). The Roadmap to a 70\% Employment Rate calls for reductions in working hours. Total working hours in Korea have fallen by 17\% over 2000-11 as the standard workweek was reduced from 44 hours to 40 by 2011. However, firms with less than five employees, which account for $19 \%$ of wage earners, are exempted from this standard. In addition, employees can work up to 12 hours of overtime per week, plus an additional eight on weekends or holidays, making a total of 68 hours per week. Annual working hours in 2014 were still $17 \%$ above the OECD average, equivalent to 354 extra hours of work each year. Firms limit the number of regular workers because employment protection makes it difficult to dismiss them, and tend to meet increased demand through overtime and hiring non-regular employees. As for workers, they are attracted by the 50\% wage premium for overtime work.

Figure 15. Working hours in Korea were long for both men and women in 2014
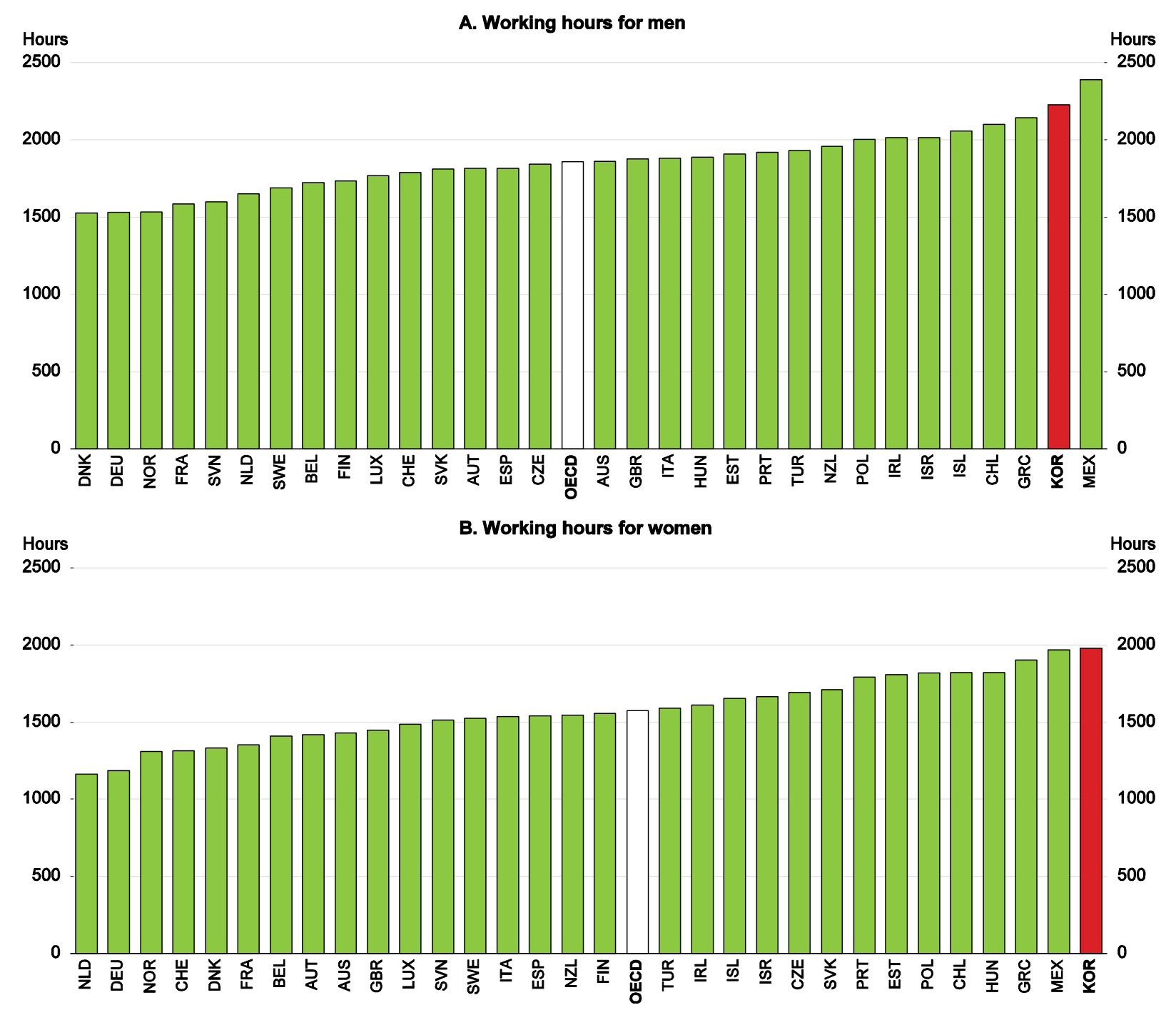

Source: OECD Family Database (http://www.oecd-ilibrary.org/employment/data/hours-worked Ifs-hw-data-en).

Long working hours for Korean men is one factor limiting their unpaid work at home to only 45 minutes a day, only $18 \%$ of the total by the parents, the lowest share in the OECD. Men's long working 
hours and small role in family responsibilities limit the employment choices of women. For women in the labour force, working time was the longest in the OECD in 2014 (Panel B) and three-quarters work more than 40 hours per week. Long hours reduce the quality of life and the fertility rate, and discourage employment. Long hours are also a threat to the health of both men and women (Yang, 2012) and contribute to Korea's high rate of industrial accidents (Yoo, 2012).

A decline in working hours would create more family-friendly workplaces, thus enhancing the wellbeing of society. In 2010, the ESDC (Box 1), which includes the government, workers and employers, set a target of cutting working time to around 1800 hours per year by 2020 and this objective was reaffirmed in the 2015 Tripartite Agreement. The government has stepped up efforts to enforce compliance with the legal limits on working time and provides subsidies for up to two years to SMEs that reduce working time and hire more employees.

However, government measures to reduce working hours have had only a limited effect. Moreover, the unions demand that any cuts in working time be based on the principles of no change in wage levels, labour intensity or job security (Lee, 2012). Indeed, after falling an average of 32 hours a year (1.4\% annual rate) during the decade to 2010, annual working hours have since fluctuated around 2100 . The Tripartite Agreement includes a number of policies to reduce hours:

- Carrying out nationwide campaigns to improve workplace culture and increase productivity.

- Including weekend and holiday work in overtime hours, thus reducing maximum working time to 52 hours per week. This law will be phased in gradually beginning with large firms, given its impact on labour costs.

- Reducing the number of occupations excluded from working-hour regulations from 26 to 10.

- Encouraging employees to use annual leave. A 2011 government survey found that on average workers take only seven days of the 11.4 days that they are granted for annual leave.

- Providing government subsidies for investment and labour costs to help SMEs cope with business difficulties and the wage losses of their employees as working hours decline.

Achieving the government's goal of reducing working time requires addressing the underlying causes of long working hours. First, working hours are longest in SMEs where labour shortages force employees to work long hours. It is important to resolve the labour mismatch problem that results in such shortages (see below). Second, the practice of long working hours should be replaced by a productive work culture, as recognised in the Tripartite Agreement. Indeed, Korea's labour inputs (relative to its population) are the highest in the OECD while labour productivity per hour of work is only 55\% of the top half of OECD countries (Jones and Lee, 2016). Long working hours are associated with low productivity in the OECD area. Firms argue that long working hours are necessary to offset low productivity, even though the law of diminishing returns makes long hours a cause of low productivity. The goal should be to raise productivity and wages, which will shift workers' preferences toward more leisure, thereby reducing working time.

In addition to reducing working time, the three-pronged approach of the Roadmap to a $70 \%$ Employment Rate includes creating "decent" part-time jobs (i.e. regular part-time jobs) and spreading flexible work arrangements. Part-time employment in Korea is relatively low, particularly for women. In $2014,16 \%$ of female employees worked part-time compared to the OECD average of $26 \%$. While parttime employment is attractive to those seeking to balance work with family responsibilities and education, such jobs in Korea are precarious, pay substantially lower hourly wages and provide less social protection.

The government aims to promote decent part-time jobs, which allow workers to voluntarily work fewer hours than full-time employees without facing the discrimination associated with non-regular 
employment. It is taking the lead with a target to hire 13000 public-sector workers on a part-time basis by 2017. To promote part-time work in the private sector, the government has provided subsidies since 2012 that are equivalent to $50 \%$ of wages (up to 0.6 million KRW per month) for one year for employers who hire regular part-time workers. In 2014, the subsidy was extended to firms that shift full-time workers to part-time work. The government also plans to establish a pool of substitute workers to facilitate the shift from full-time to part-time work by current employees (Ministry of Employment and Labour, 2015).

The government is also promoting work practices that allow employees greater flexibility about how much, where and when they work, while assuring employees who opt for such flexibility that they will not be shunted off to low-quality jobs. Under the Tripartite Agreement, the government will extend the reference period for flexible working time from two weeks to one month and compile a list of jobs where employees should be allowed to determine their schedule. Ultimately, the private sector has a major responsibility to promote gender equality and work-life balance by making work schedules better fit family schedules and encouraging, rather than penalising, parents who take leave to care for children.

\section{Facilitating women's return to work after an absence from the labour market}

Following marriage and childbirth, women stay out of the labour force for about ten years on average (Hong and Lee, 2014). The issues discussed above that prompt their departure - notably the lack of highquality childcare and work-life balance - delay or even prevent women's return to the labour force. Given the close link between seniority and wages, any absence from the labour market has a strong impact on earnings. Indeed, the wage gap between women with children and men is $45 \%$, compared to only $13 \%$ for childless women (Walker, 2014). The gender wage gap for young women (aged 25-29) is close to the OECD average of around 10\% (Figure 16), given that 30 is the average age when Korean women have their first child. For the 40-44 age group, the gap reaches $41.5 \%$, the highest in the OECD. The overall gender wage gap for the working-age population in Korea was the largest in the OECD area at $37 \%$ in 2013 (Panel B). While the law requires equal pay for equal work, the gender wage gap is falling very gradually, from $40 \%$ in 2000 to 37\%. Meanwhile, the OECD average fell from 19\% to 15\%. The large gap in Korea is surprising, given that the university graduation rate for women is higher than that for men among the 25 to 34 population and indeed is the highest in the OECD (Kim, 2011).

The large gender wage gap discourages women, particularly those with higher education, from returning to the labour force. Indeed, the employment rate of women in Korea with a tertiary education was the lowest in the OECD in 2014, while the rate of those with less than a high school education was above the OECD average (Figure 17). Given their high rate of university graduation, the low employment rate of women represents a large opportunity cost for the Korean economy.

Reforming the wage system to emphasise performance and reduce the importance of seniority would help narrow the gender wage gap. The seniority-based system was suitable for the high-growth era, as firms expanded rapidly and the average tenure and age of workers were relatively low. However, as growth slowed and tenure and seniority rose, labour costs increased sharply. The government has been encouraging a shift from seniority to pay based on performance and job responsibilities. Shifting from the traditional emphasis on seniority towards a meritocratic approach emphasising performance has prompted opposition from workers (Rowley and Yang, 2009). Given the difficulty of changing the wage-setting system, it is essential to also address other issues that contribute to the large gender wage gap: $i$ ) labour market dualism; ii) the concentration of women in industries with lower wages; and iii) the small share of women in management positions. 
Figure 16. Korea's gender wage gap rises with age and is the largest in the OECD

In 2013 or latest year available for full-time employees

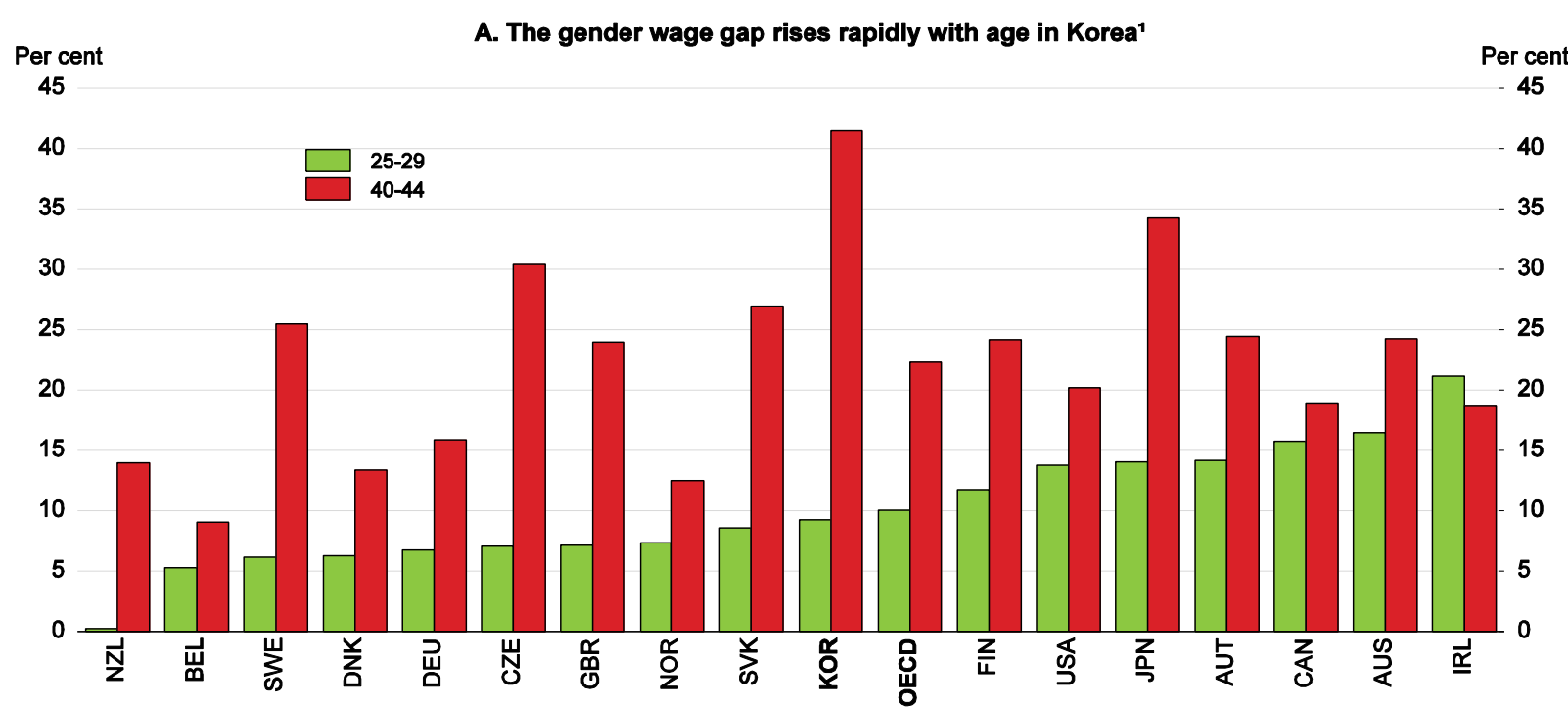

B. The gender wage gap in Korea is the largest in the OECD²

Per cent

40
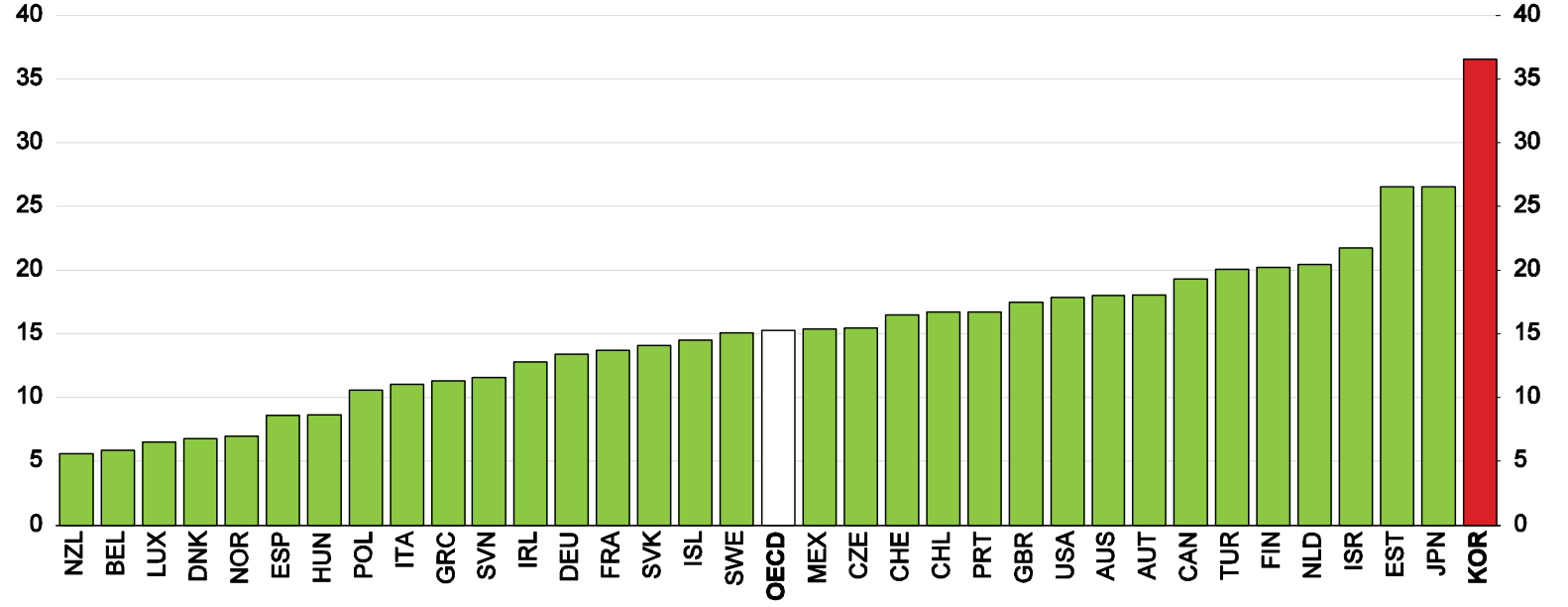

1. The difference between male and female mean wages divided by male mean wages.

2. The difference between median earnings of men and women relative to median earnings of men, full-time employees.

Source: OECD Earnings Distribution Database (http://www.oecd.org/social/income-distribution-database.htm).

Labour market dualism and the gender wage gap

Non-regular workers earned only $64.3 \%$ as much per hour as regular workers in 2014 (Table 2). The concentration of women in non-regular jobs thus contributes to the large wage gap. In 2015, 40.2\% of female employees were non-regular compared to only $26.5 \%$ of men (Figure 18). Breaking down dualism is thus crucial to reduce the gender wage gap and promote employment opportunities for women.

\section{The concentration of women in low-wage industries}

A second factor is the concentration of women in industries that pay low wages (Figure 19). Data for 41 industries (covering manufacturing, services, construction, mining, utilities and agriculture) in 2014 show an inverse correlation between the wage rate and the share of employees that are women. While $74 \%$ of female employees worked in the service sector, where wages are substantially below the national 
average, only $23 \%$ worked in manufacturing, where wages are much higher. Policies to boost productivity in the service sector (Chapter 1) would thus help narrow the gender wage gap.

\section{Figure 17. Educated women in Korea have a relatively low employment rate}

In 2014 or latest year available

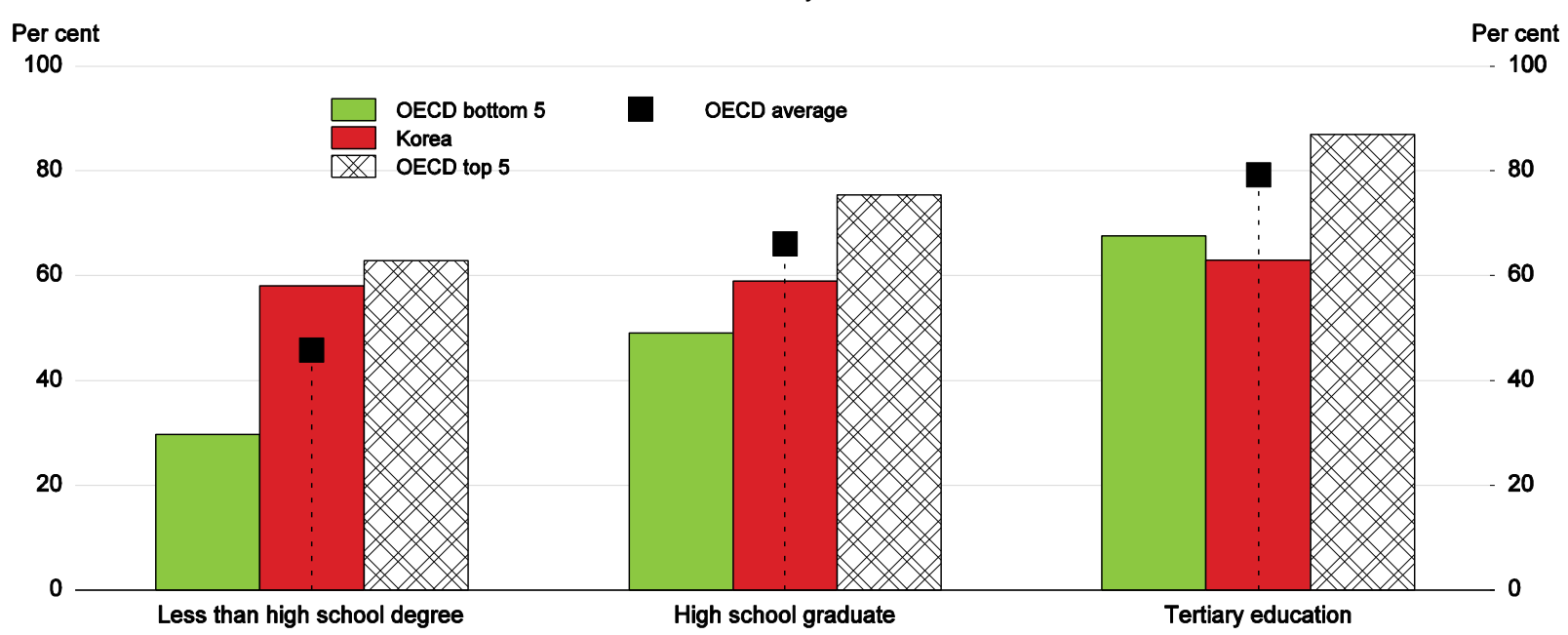

Source: OECD (2015a), OECD Education at a Glance 2015.

It is important to address the factors that push women toward low-wage sectors. First, female employment is concentrated in industries with shorter working hours, suggesting that improving work-life balance and childcare could attract more women to high-wage industries. Second, as in many countries, women tend to follow different educational paths. For example, women in Korea account for only about $20 \%$ of tertiary degrees in computing qualifications and $24 \%$ in engineering. The small share in these fields may reflect the different level of achievement in math. While Korea scored first in math in the 2012 PISA test, there was a significant gap between boys and girls.

Figure 18. Women are concentrated in low-paying non-regular jobs

Employees by employment status as a percentage of total employment in 2015

Men

Non-regular (part-time, fixed-time and other): $26.5 \%$

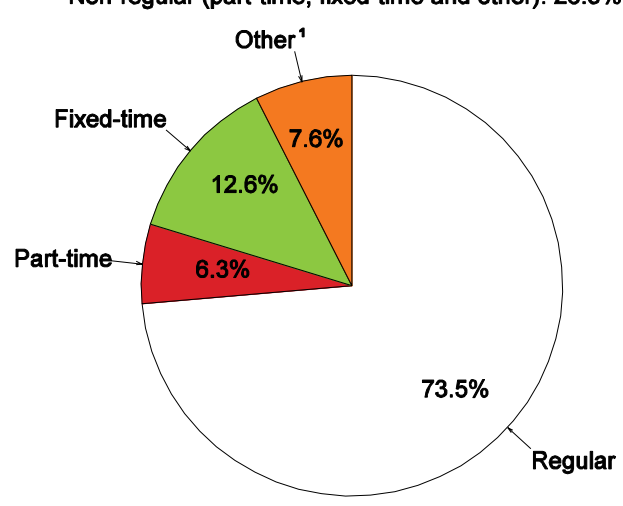

\section{Women}

Non-regular (part-time, fixed-time and other): $40.2 \%$

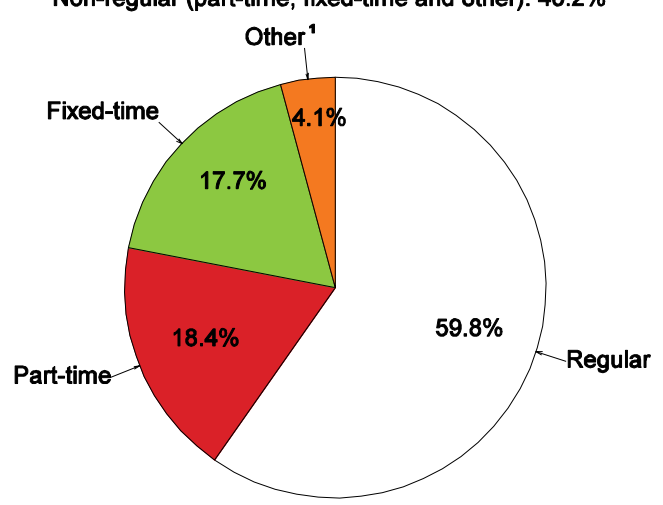

1. Includes temporary employees and atypical workers (dispatched, daily on-call, in-house, independent contractors, etc).

Source: Statistics Korea, Economically Active Population Survey, August 2015. 


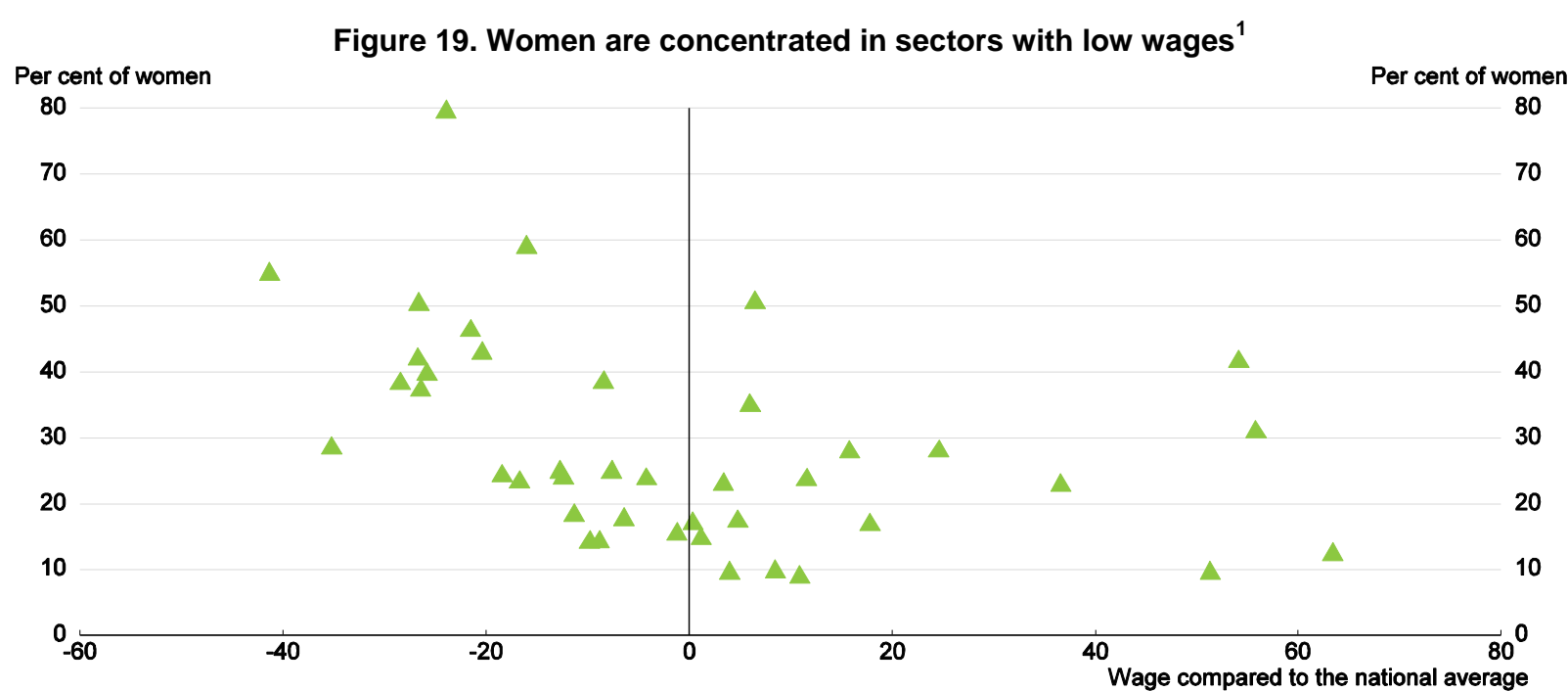

1. The 41 industries cover manufacturing (24 industries), services (13 industries), agriculture, forestry and fishing, mining, utilities and construction. Wages include the basic wage, overtime pay and bonus payments.

Source: Statistics Korea; OECD calculations.

\section{The lack of women in management}

The long absence of women from the labour force following childbirth and their concentration in non-regular employment limit their rise up the corporate ladder. The share of women on corporate boards in Korea, at 2.1\% in 2014, lagged behind other Asian economies, such as Malaysia (12.8\%), Indonesia (12.2\%), Hong Kong, China (11.1\%), China (9.2\%) and Singapore (7.4\%) (Vinnicombe et al., 2015). Korea has no targets to raise the share, although it has long had quotas on candidates for the National Assembly. The share of women in management in Korea was the lowest in the OECD area at $11 \%$ in 2013 (Figure 20), contributing to the gender wage gap. The Equal Employment Act was modified in 2005 to require firms with more than 500 workers to provide data on women in management. The government gives improvement orders to those that do not reach $70 \%$ of the average share by firm size or industry. In 2014, the government decided to give preference in public procurement to firms with a higher share of women in management and publicly name companies that fall short (Ikemoto and Hang, 2014).

Figure 20. The share of women in management in Korea was the lowest in the OECD in 2013

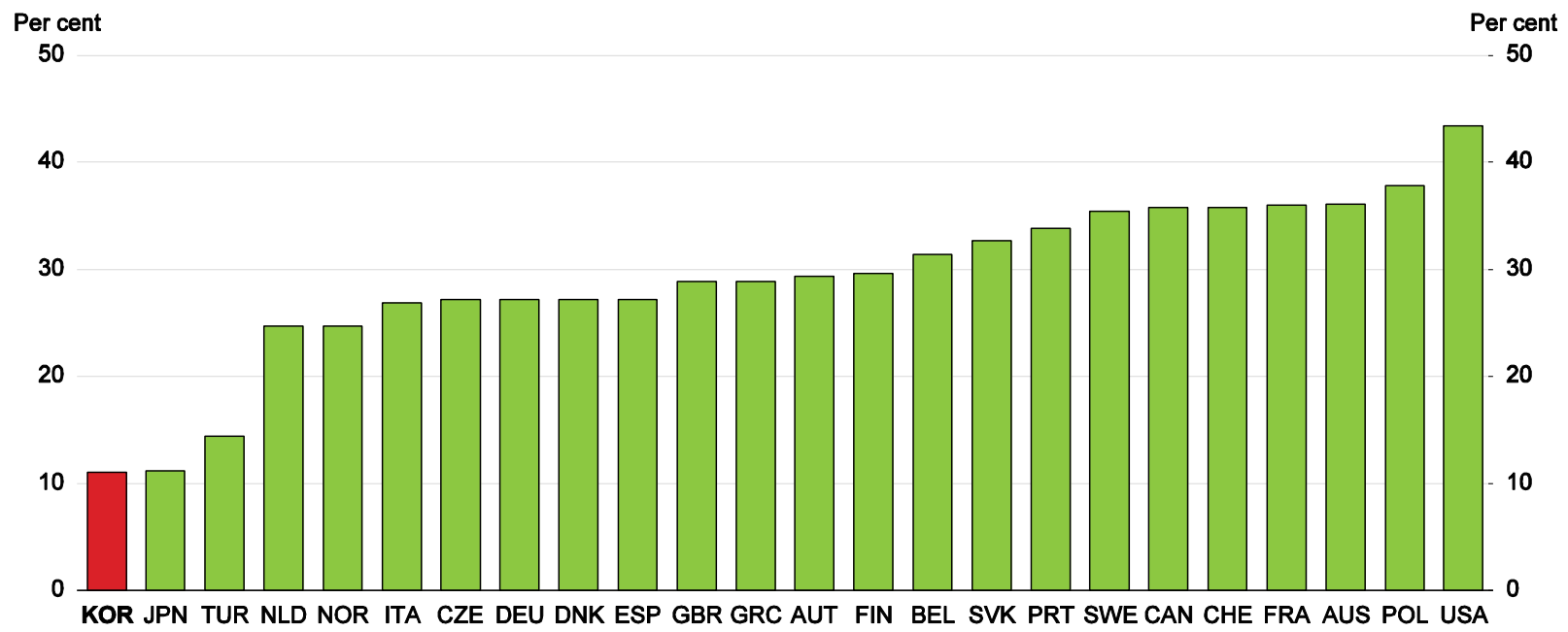

Source: OECD Family Database (http://www.oecd.org/gender/data/employment/). 


\section{Integrating youth into the labour market}

Korea's youth employment rate has fallen significantly since 2004 (Figure 21). Despite an upturn in 2014, it was the sixth lowest in the OECD area at 40.7\%, well below the OECD average of $51.2 \%$ (Panel B). At the same time, $18 \%$ of youth were neither in employment nor in education or training - the so-called NEETs -- although their number may be overestimated.

The Tripartite Agreement sets out a range of policies to boost youth employment:

- Firms that create more jobs for youth will receive greater government support though subsidies, preferential treatment in tax audits and public procurement, and investment tax credits.

Figure 21. Korea's youth employment rate has fallen and is well below the OECD average Employment rate for the 15-29 age group
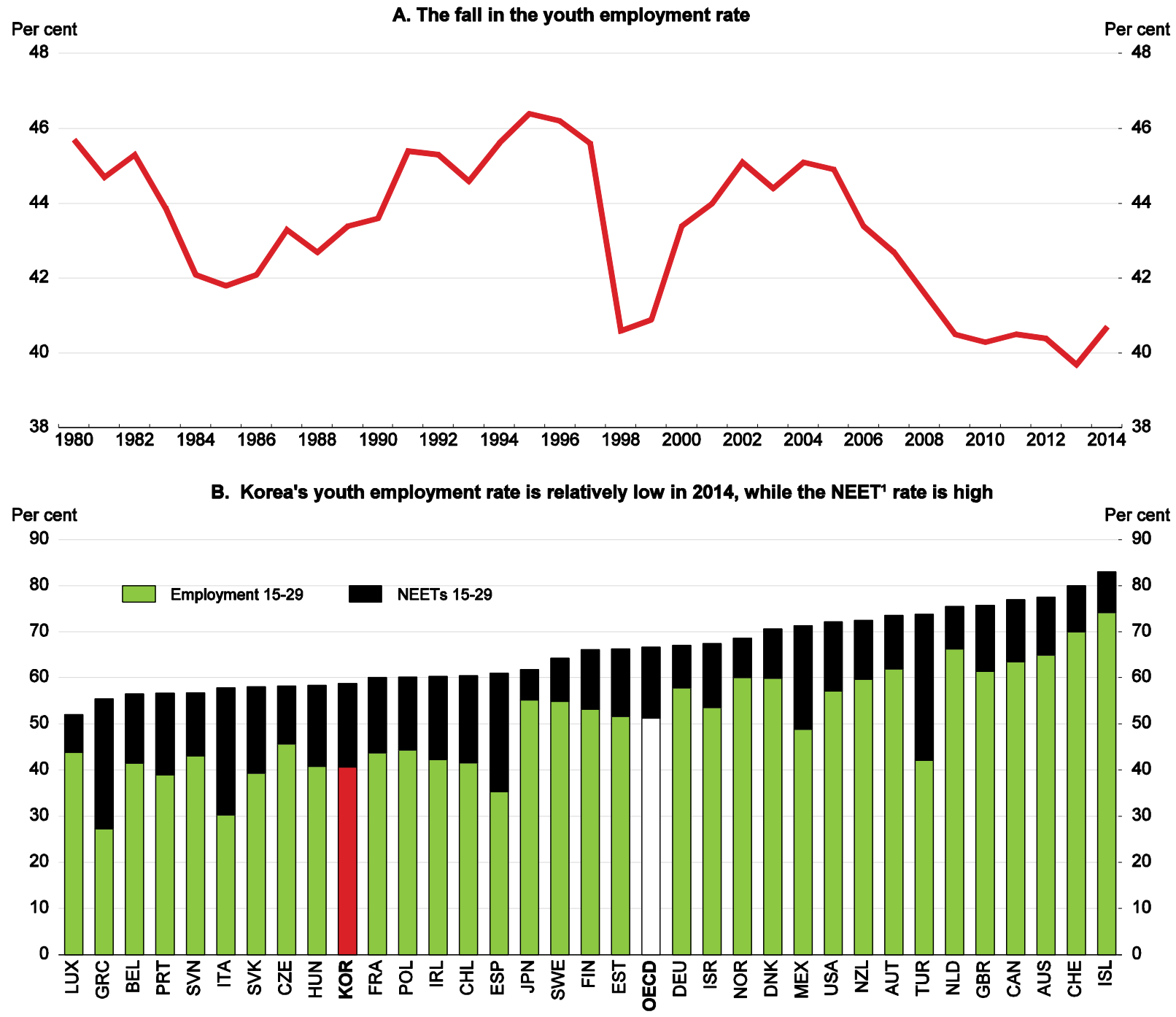

1. Data on the category ISCED 4, which captures programmes that straddle the boundary between upper secondary and postsecondary education, are not available in Korea and 11 other OECD countries. The chart therefore overestimates the number of youth who are classified as NEETS in these countries.

Source: OECD (2015), Labour Force Statistics; OECD (2015a), Education at a Glance 2015. 
- The tripartite partners will adjust wages and working hours to expand job opportunities for youth. Firms will use the money saved by adopting a wage peak system for older workers and by having highly-paid employees refrain from seeking wage hikes to create jobs for youth.

- To facilitate the entry of young people into SMEs, the tripartite partners will strive to narrow the gaps in wages and welfare benefits between large and small firms and improve the competitiveness of SMEs. The government will identify SMEs with high potential, including future-oriented "hidden champions", and provide them with more support.

- Social support will be strengthened for social enterprises, co-operatives, business start-ups, and public social service jobs, as youth prefer to work in such sectors.

\section{Mismatch problems in the labour market for youth}

Raising youth employment requires resolving the mismatch between the skills acquired in school education and those demanded by the business sector (Y. Kim, 2015). The share of high school graduates advancing to higher education increased from 33\% in 1990 to $83 \%$ in 2008, doubling the number of young people graduating from university each year. Although the rate fell to $71 \%$ in 2014 , the mismatch problem is still evident, including among the youth who find jobs. Youth in the 16-24 age group who are employed are 2.2 times more likely to be over-skilled for their jobs than employees in the $25-44$ age group. For the OECD area, the average ratio is 1.4 times (OECD, 2013a). For the 16-29 age group, 37\% were mismatched for their jobs in terms of their field of study and literacy skills (Figure 22), although mismatch in terms of qualifications was relatively low. Another study found that the level of mismatch in Korea is high and strongly correlated with the youth employment rate (Dao et al., 2014).

Figure 22. Korea has a relatively high rate of mismatch among young people

Mismatch among youth (16-29) by type of mismatch as a percentage of all youth employment

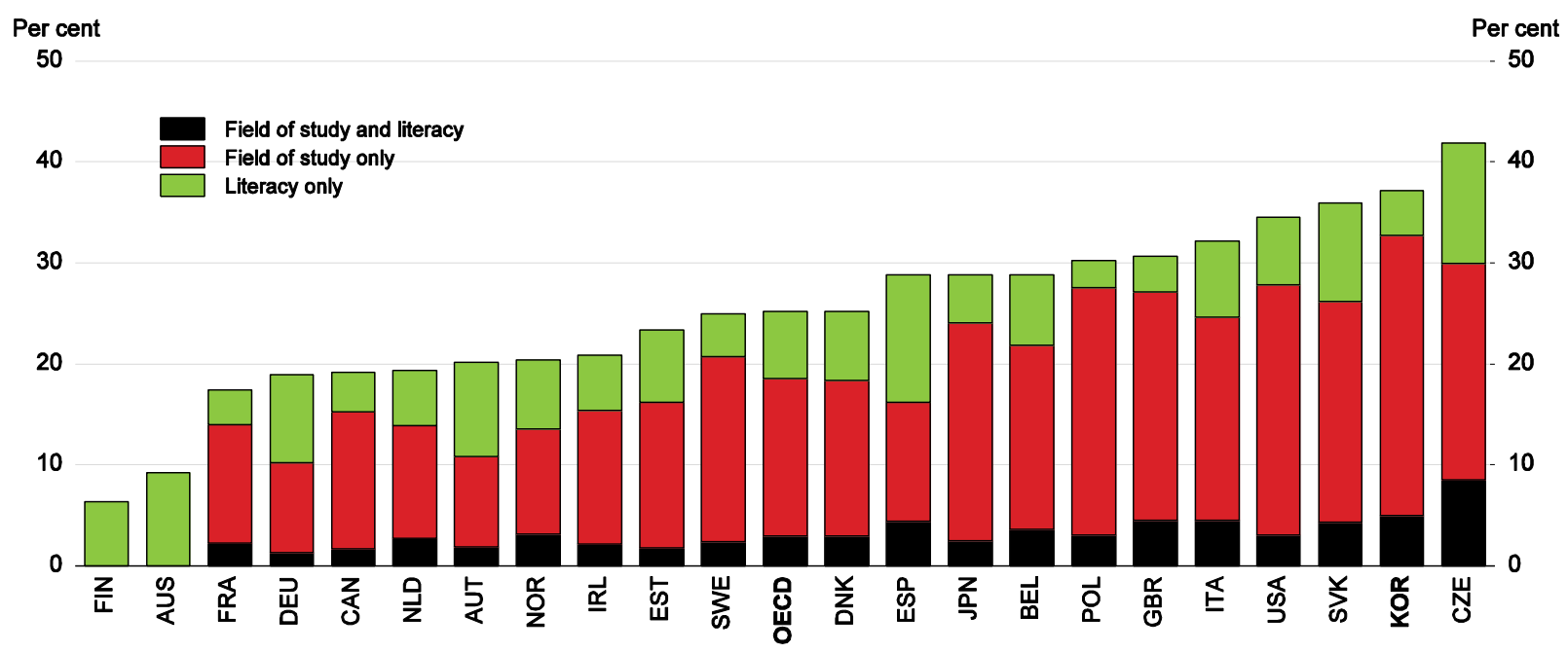

Source: OECD (2014b).

Youth with tertiary education expect to be employed as a regular worker. To many, no job is better than being trapped in non-regular employment. In addition, they want to avoid SMEs, where job security is low and wages are only about half of those in larger firms. Meanwhile, SMEs face labour shortages that are partially filled by foreign workers. Moreover, young people face social pressure to work in large firms rather than pursuing jobs based on their own preferences and uniqueness (Y. Kim, 2015). 
As the rising number of university graduates has outstripped the number of new high-quality jobs, many young people pursue a wide range of preparatory activities, such as overseas language studies, to improve their employment prospects. For men, such activities come on top of around two years of mandatory military service. A 2014 study of employed university graduates found that $45 \%$ had taken a leave of absence from school to prepare for employment, suggesting that the formal education system is not adequately preparing students for the job market. However, labour market outcomes, such as employability, productivity and wage levels, do not suggest that such outside activities are effective in building human capital. Indeed, wage levels are not connected to the length of the absence from formal education (Kim and Jeon, 2014). In addition, some students delay graduation, as they are more likely to find a job while still in school (Yang, 2015). The individual and social benefits of such preparatory activities do not justify the additional delay in entering the labour market. The late entry into the labour market, combined with the early age of retirement (see below), shortens careers and contributes to the high rate of poverty among the elderly.

The large number of university graduates who are unable to find jobs matching their skill levels pushes down the youth employment rate and pushes up the rate of NEETs (Figure 22). Consequently, Korea is one of the few countries in which the rate of NEETs for tertiary graduates is higher $(24.8 \%)$ than for the overall 15-29 age group (18.0\%) (Figure 23). Periods of inactivity have a negative long-term effect on youth. Those who were not engaged in education or the labour market in 2000 had a lower employment rate over 2007-09 than those who were (Table 7). Moreover, those who had a period of inactivity were more likely to be non-regular workers at lower wages. The longer the period of inactivity, the stronger the negative impact on labour market outcomes.

Figure 23. The rate of NEETs in Korea is higher for tertiary graduates

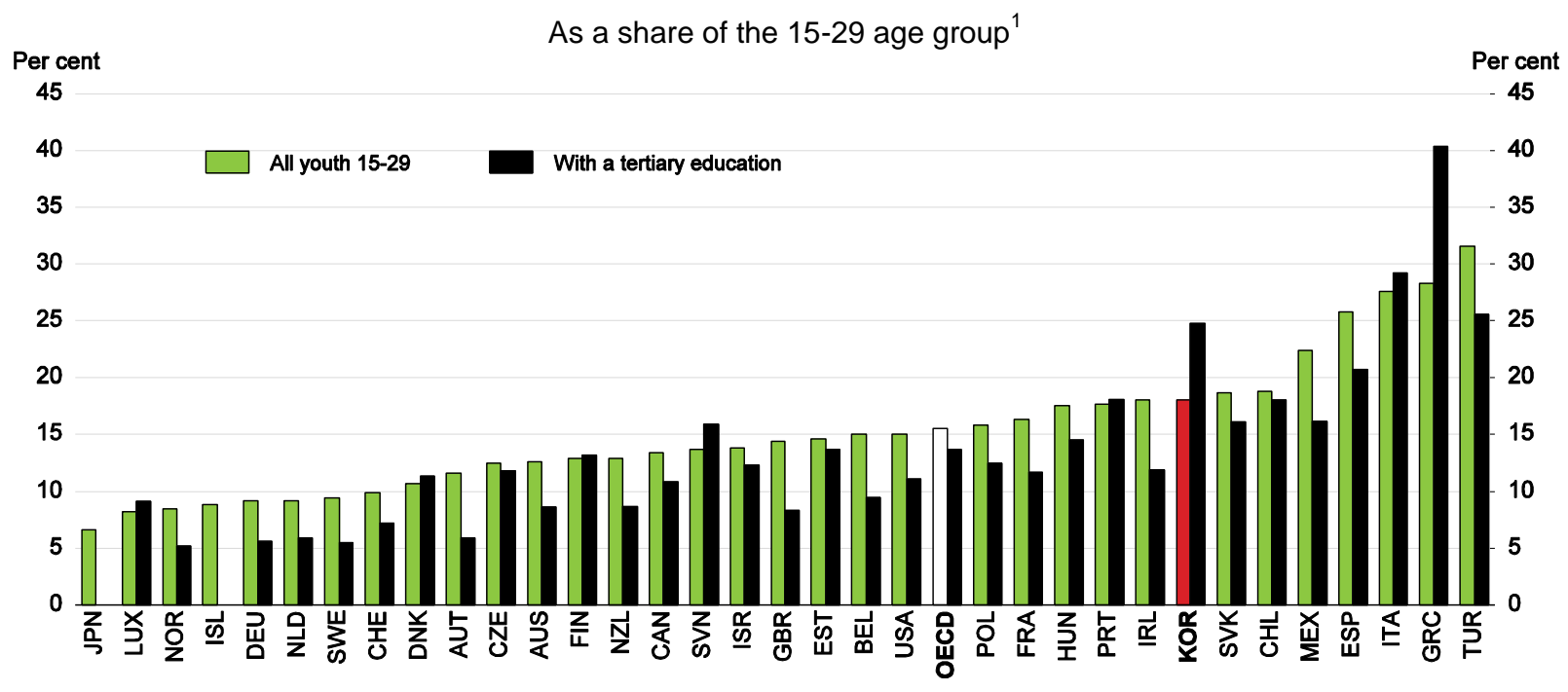

1. Data on the category ISCED 4, which captures programmes that straddle the boundary between upper secondary and postsecondary education, are not available in Korea and 11 other OECD countries. The chart therefore overestimates the number of youth who are classified as NEETS in these countries.

Source: OECD (2015a), Education at a Glance 2015.

\section{Policies to expand job opportunities for youth}

In the long run, changes in the production structure in line with the skills of youth will help to reduce the mismatch problem, underlining the importance of promoting innovation. In the shorter term, a range of policies are important. First, breaking down labour market dualism would reduce the number of educated youth who prefer no job to the stigma of being a non-regular worker. In addition, relaxing rules on 
dismissing workers may make firms less hesitant to hire regular workers (OECD, 2014b). Second, career guidance is important to provide information concerning the job market to help youth make good choices about their education. In most OECD countries, student preferences, rather than potential labour market outcomes, remain the key driver in choosing the field of study (OECD, 2014b). Improving the labour market information available to young people is thus a priority.

Table 7. A period of inactivity for youth has a long-term negative impact on labour market outcomes

Status in $2007-09^{1}$ in per cent for a worker who was:

\begin{tabular}{l|ccc|}
\hline & $\begin{array}{c}\text { Continuously engaged } \\
\text { in education or the } \\
\text { labour market }\end{array}$ & $\begin{array}{c}\text { Not engaged in education } \\
\text { or the labour market in }\end{array}$ & $\begin{array}{c}\text { Not engaged in education } \\
\text { or the labour market in both } \\
2000 \text { and 2001 }\end{array}$ \\
\hline Employed & 67.3 & 2000 & 48.1 \\
Unemployed & 3.2 & 60.7 & 6.9 \\
Economically inactive & 29.5 & 5.0 & 45.0 \\
Non-regular employee & 18.8 & 33.8 & 31.6 \\
Hourly wage $^{2}$ & 100.0 & 23.0 & 78.3 \\
\hline
\end{tabular}

1. Based on the Korea Labour and Income Panel Survey.

2. The average wage of workers who were continuously engaged in education or the labour market is set at 100.0.

Source: Nam and Kim (2013).

Academic credentialism - the emphasis on where a person studied rather than on their abilities and accomplishments - has driven the emphasis on university degrees. A 2010 government survey reported that only $6 \%$ of the parents of middle school students wanted their children to attend vocational high schools (Jones, 2013). Respect for skilled craftsmen in Korea, given its Confucianist heritage, has not been as high as in some OECD countries. The fall in the share of high school graduates advancing to tertiary education since 2008 suggests some progress in this regard.

Enhancing the link between education and the business sector is also essential to address mismatch. In particular, combining work and study helps youth develop the skills required in the labour market, thereby shortening and smoothing the transition from school to work. The share of youth combining work and study in Korea in 2012 was only $20 \%$, about the half of the OECD average. Moreover, only $12.3 \%$ of employees gained experience as apprentices (OECD, 2014b).

Korea has launched three important initiatives to reduce labour mismatch by combining school and work experience at the secondary level. First, by end-2015, Korea had completed 847 out of 887 National Competency Standards (NCS), which identify the knowledge, skills and attitudes necessary to perform tasks by sector and level of industry. The NCS are playing a key role in revising training standards and setting the curriculum for vocational education. Second, it introduced Meister high schools, which allow students to combine work and study. Third, in 2013, the government launched a "Work-Learning Dual System" that includes high school students (Box 3). However, the two initiatives cover only 5.6\% of vocational high school students, who account for a fifth of the total number of high school students, suggesting the need for further expansion.

\section{Making better use of older workers to promote inclusive growth and reduce poverty}

The employment rate in Korea for the 50-64 age group in 2014 was the eighth highest in the OECD at $70 \%$. Yet their poverty rate was the second highest in the OECD at $15.5 \%$, nearly 1.5 times the OECD average (Figure 24). Older workers face a double penalty - low-quality, low-paid jobs and little social protection. In particular, the maximum EITC benefit to households without dependent children is only $4 \%$ of the average wage. Moreover, the eligibility criteria on financial assets and "the family support obligation rule" limit assistance to older persons form the EITC and the BLSP. 


\section{Box 3. Policies to combine school and work experience at the secondary level}

The Vocational High-School Advancement Plan (2010-15) aimed to build vocational schools based on industrial needs and sector-specific skills, favouring employment over college admission after high-school graduation. Improving the quality and relevance of vocational education is a priority: the average employment rate of junior college graduates was just $61 \%$ and that of specialised vocational high-school graduates was $41 \%$ in 2013 .

A key part of the Plan was the creation of Meister schools. There are now 41 Meister schools nationwide, with more than 16000 students, and six more are planned for 2016-17. The job placement rate for Meister school graduates is more than $90 \%$, compared to only $44 \%$ for traditional vocational high schools.

A second initiative is the Work-Study Dual System, which aims to involve 70000 students/workers and 10000 companies in a Korean-style apprenticeship system:

- At the high school level, a pilot programme has been launched in nine schools since March 2015. By end2017, the System is to be available in all 203 specialised vocational high schools.

- At the junior college stage, "Uni-Tech" will promote integrated high school-junior college education based on the NCS for students alternating between school-based education and in-company training.

- At the university level, "Industry Professional Practice", a system of work-study, will be introduced.

At present, 2322 firms and nearly 13000 students are participating in the System, focused on machinery (45\%), telecommunications $(21 \%)$, and electric machinery (13\%). However, the System faces financial challenges as most of the participating companies are SMEs, with limited financial resources to provide training. Government subsidies are thus necessary to induce the participation of both companies and students. Without government subsidies, the cost to firms and students is estimated to exceed the benefits: the net costs were 5.7 million KRW (USD 5 000) and 1.5 million KRW, respectively (Jun and Lee, 2015; Kang et al., 2014). To limit the fiscal cost as the programme expands, it should be reformed to make it more profitable to firms and students. For example, SMEs could establish joint training centres, which could be located on the local campuses of the Korea Polytechnic University. In addition, increasing the training quality would boost the returns to both firms and students.

Figure 24. Relative poverty rates for persons over 50 are very high in Korea Percentage in $2013^{1}$

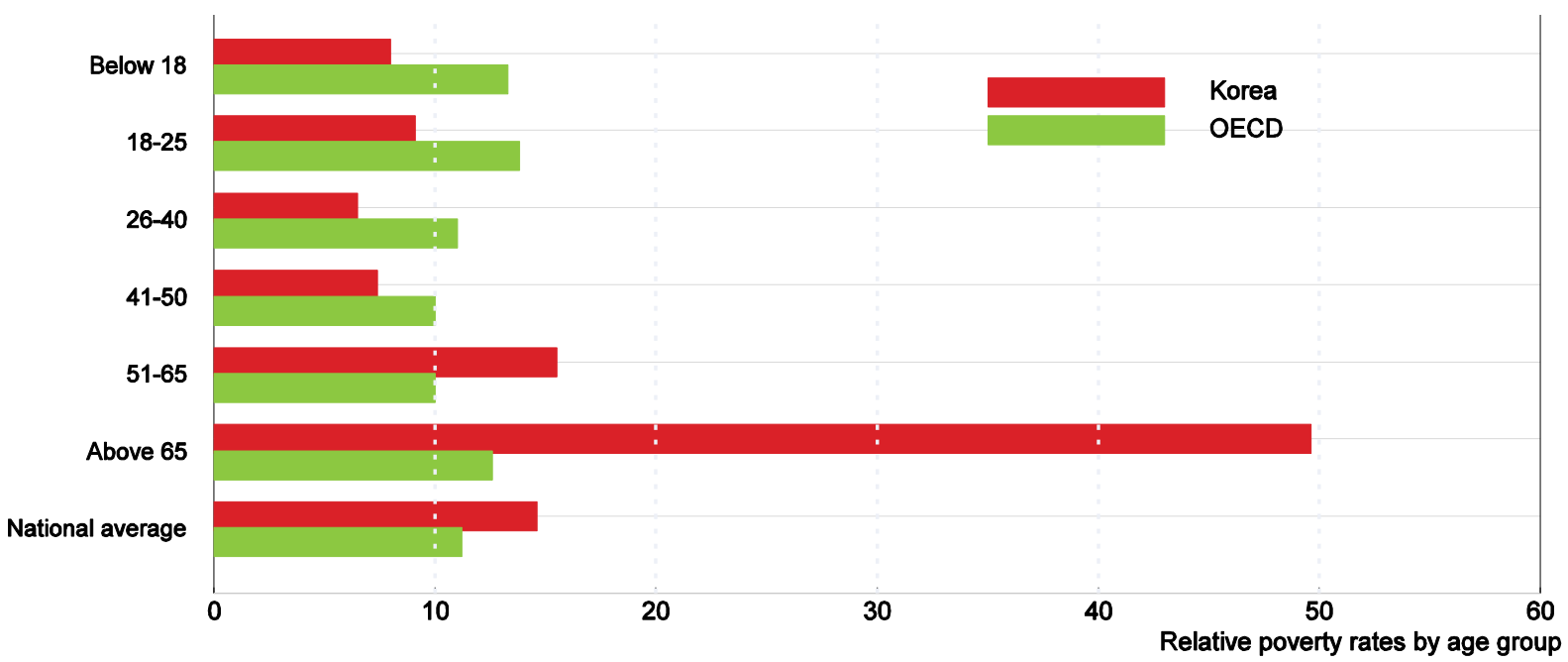

1. Relative poverty is measured by reference to median income, not taking into account household assets and liabilities.

Source: OECD Income Distribution and Poverty Database (http://www.oecd.org/social/income-distribution-database.htm).

The main issue, therefore, is the quality of jobs for older workers rather than the employment rate. Although the mandatory retirement age (the age at which the employment contract automatically 
terminates) set by firms is 58 on average, workers leave at age 53 on average as firms push workers out through incentives (bonuses for "honorary retirement") or penalties (shifting workers to undesirable jobs) (Klassen, 2012). Many become self-employed in services, contributing to the low productivity in that sector. Of those who remain employees, many become non-regular workers, often in sectors that are unrelated to their career. In Korea, 27\% of workers aged 55-64 have less than six months of job tenure compared to 5\% in the OECD area (Figure 25). Similarly, the share of workers with job tenure of more than five years falls sharply in Korea after age 50, in contrast to the OECD area. The short tenure reflects the high share of temporary employment at 35\% for the 55-64 age group in 2014 compared to an OECD average of $7 \%$ (Panel B). Wages thus fall significantly as workers age.

Figure 25. Older workers in Korea are concentrated in temporary, low-paying jobs

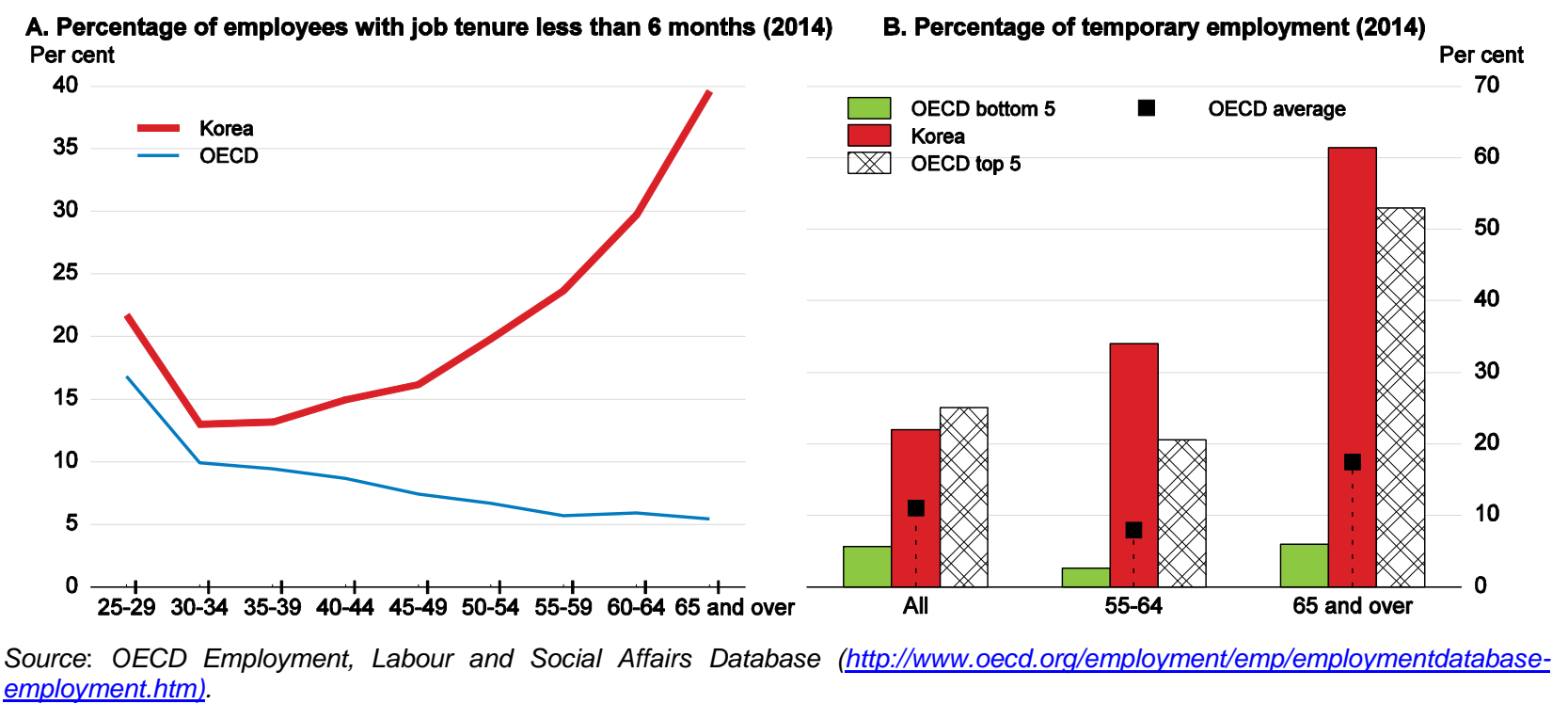

The concentration of older workers in temporary, low-paying jobs also reflects low education and skills. The education gap between youth (aged 25-34) in Korea, who have the highest share of tertiary graduates in the OECD, and older workers was the largest in the OECD in 2013 (Figure 26). The generational gap in skills is even larger. For example, the share of youth (aged 16-24) with a "good ability to use computers and solve problems" in Korea is the highest among OECD countries, while for older workers the share is the second lowest (Panel B).

The low skills of older workers and the seniority-based pay system result in a significant gap between wages and productivity as workers age, creating a culture of early retirement from firms. To maintain competitiveness, firms have an incentive to reduce employment of older workers. A recent survey among people aged $20-50$ by Statistics Korea found that $82 \%$ of respondents are afraid that they will have to leave their main job before age 60 and $56 \%$ before age 55. Nevertheless, the seniority-based wage system is strongly supported by workers, as it guarantees a high income when they face high expenses.

\section{Policies to promote regular jobs for older workers}

The Statistics Korea survey reported that $82 \%$ of respondents would like to work until at least age 65 , while 70 is the desired retirement age for $32 \%$. Greater employment for older workers creates concern that it would reduce job opportunities for young people. However, this argument is based on the fallacy that an economy has a fixed number of jobs. In reality, limited opportunity for older people simply decreases economic activity. Indeed, the correlation between employment rates for younger and older workers across OECD countries is strongly positive (Figure 27). Moreover, countries where the employment rate of older 
workers has increased the most over the past 15 years are those where the employment rate of youth has fallen less (Panel B). Boosting the employment of older persons is thus a positive factor for youth employment.

Figure 26. The education and skill gap between younger and older workers in Korea is large
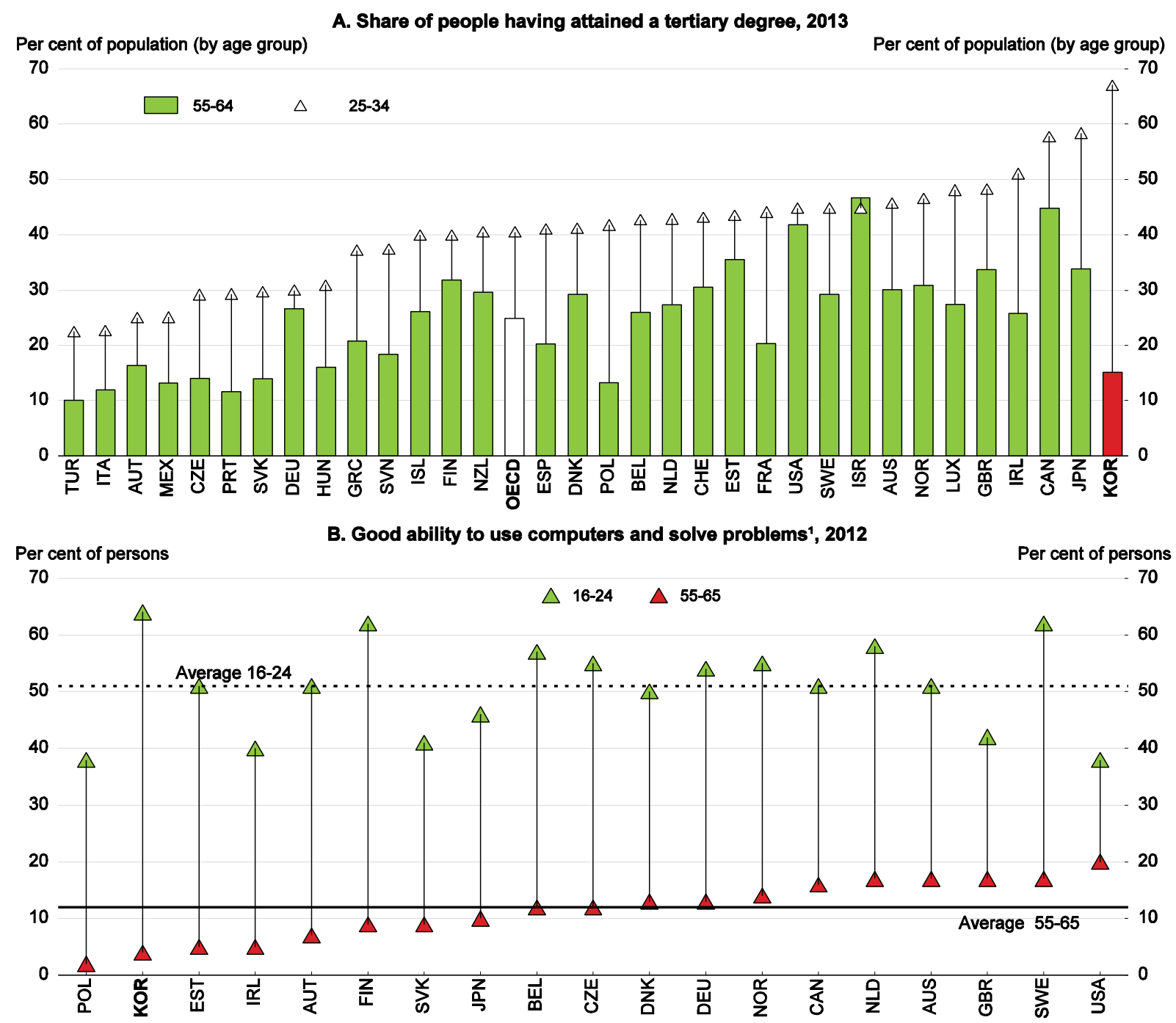

Source: OECD Education at a Glance Database; OECD (2013c).

Beginning in 2016, firms with over 300 workers are required to set a mandatory retirement age at age 60 or above and the law will be extended to smaller firms in 2017. While this policy will help lengthen workers' careers, it places additional burdens on firms, to the extent that the higher retirement age is respected, by widening the gap between productivity and wages. To limit the negative impact, the government is paying various subsidies to maintain the employment of older workers. In addition, the new law mandates measures to accommodate the higher retirement age, notably by amending the wage structure. Otherwise, firms would face a loss in competitiveness that would prompt them to continue pushing out older workers before the mandatory retirement age. A flexible wage structure is needed to compensate for the lack of employment flexibility.

Since the 1997 crisis, the government has been encouraging the introduction of the "wage peak" system, which freezes or gradually reduces workers' wages during the few years prior to the company's 
retirement age, while promising workers that they will not be forced into early retirement. It thus reduces the financial burden on firms of keeping older workers, while increasing workers' lifetime earnings. The share of firms with more than 100 workers that had introduced the wage peak system rose slowly from $9.6 \%$ in 2009 to $21.0 \%$ in 2015 , in the face of opposition from workers, who fear that it will undermine the seniority-based wage system. The age at which wages start to fall, the size of the reduction and the age to which early retirements are postponed must be agreed by management and workers in each firm. While firms welcome the wage peak system, its introduction has prompted strikes.

Figure 27. Youth employment rates are positively correlated with those of older workers in the OECD
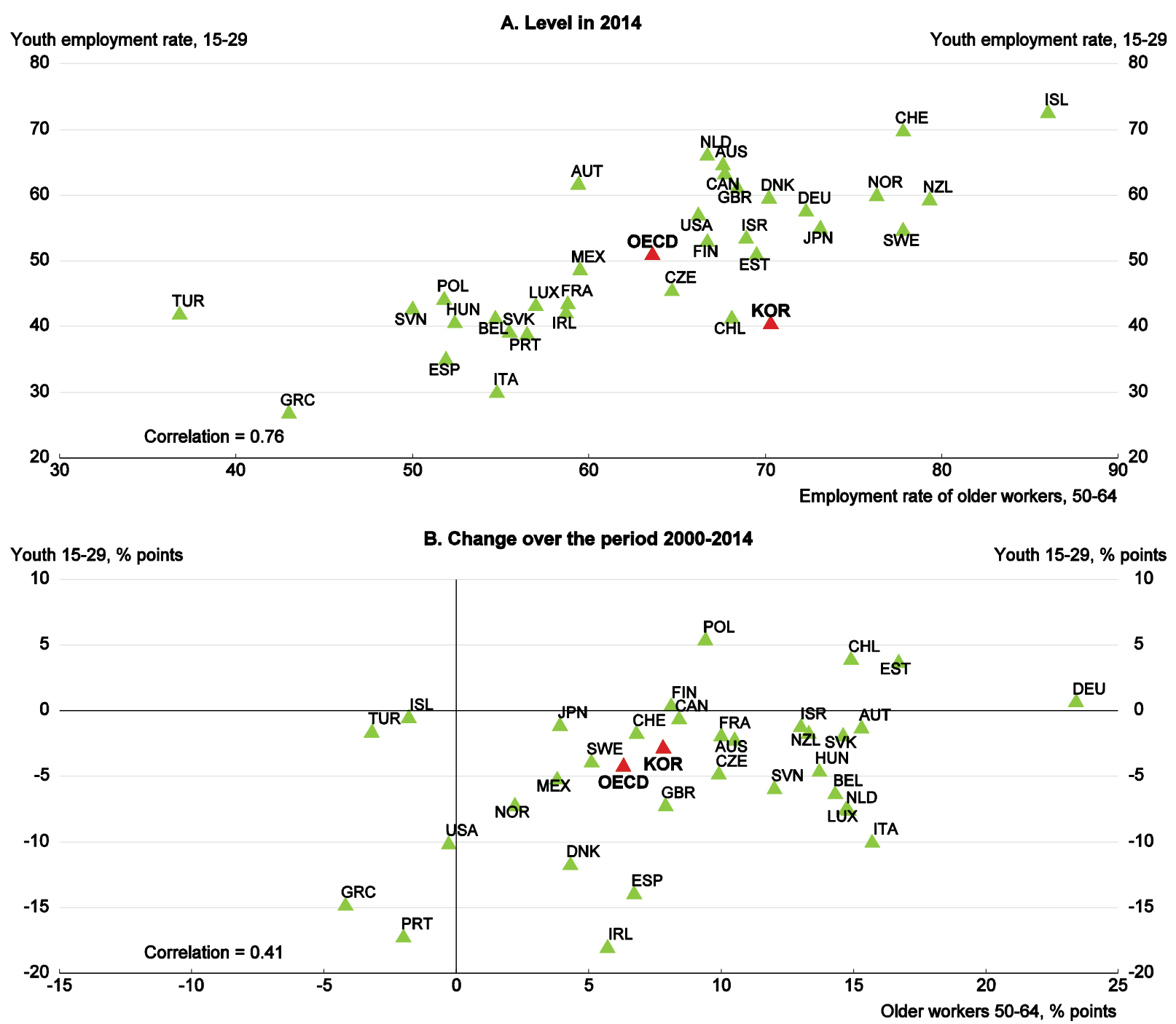

Source: OECD Labour Force Statistics Database (http://www.oecd-ilibrary.org/employment/data/labour-market-statistics IfsIms-data-en).

The Tripartite Agreement pledges to increase the use of the wage peak system to ensure a "soft landing" from the hike in the retirement age. The government is to contribute by providing advice and subsidies. While the wage peak system is an appropriate short-term response to the retirement age hike, the ultimate objective should be a flexible wage system that allows workers to continue their career as long as they wish, while abolishing the right of firms to set mandatory retirement ages, as has been done in a number of OECD countries. This objective would be best achieved by a performance-based wage system, which would also promote female employment. 
In addition to reforming the wage system, increasing the human capital of older workers by investing in life-long learning would help bring wages and productivity into line. Lifelong vocational training is critical to ensure that workers can upgrade their core skills throughout their working life so as to reduce the practice of early retirement. In Korea, only $21 \%$ of the 55-64 age group participated in formal or nonformal education or training related to their job in 2012, compared to the OECD average of 28\% (Figure 28). A similar proportion of older workers in Korea wanted to participate in such training, but were unable to do so, primarily because they were too busy at work. Although employees aged 50 and over account for a third of employees, they received only $8 \%$ of government subsidies for vocational training and education in 2014 and 12\% of the funds for Individual Training Accounts. The goal should be to create a virtuous circle between lifelong learning, workers' productivity and earnings. The NCS provide a useful framework for vocational education and training and could also help link earnings, performance and pay. The $O E C D$ Skills Strategy for Korea (OECD, 2015d) sets out a comprehensive approach to develop skills from childhood to adulthood.

Figure 28. The share of older workers receiving vocational education and training in Korea is low

Share of persons in the 55-64 age group in 2012

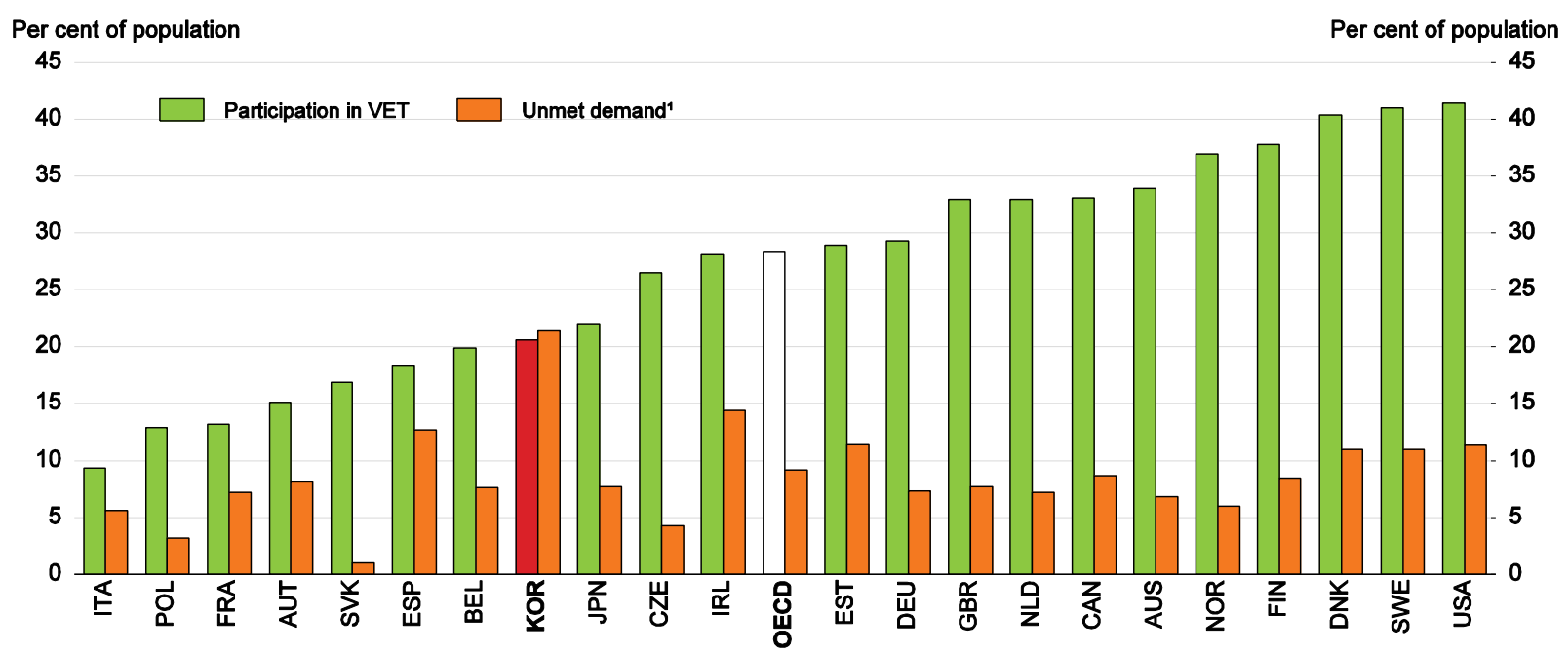

1. Persons who wanted to participate in vocational education and training but did not.

Source: OECD (2013c).

A reform of the wage-setting system and expanded opportunities for lifelong learning should be accompanied by other reforms to help workers extend their careers. First, as discussed above, it is essential to break down labour market dualism, which results in second-class treatment of non-regular workers. Second, the plan to reduce working time would facilitate regular jobs for older workers.

\section{Reducing poverty among older persons}

Extending the careers of older persons would also sustain output growth and reduce poverty among older persons, both while they are working and after retirement. Remaining longer in the core labour force, even at somewhat reduced wages under the wage peak system, would provide more income than nonregular jobs, self-employment or unemployment. It would also boost workers' contribution period to the NPS and company pension, resulting in larger old-age pensions, and allow them to accumulate savings for retirement.

However, more needs to be done to address Korea's most urgent social problem - the high rate of poverty among the elderly population. In 2011, $49.6 \%$ of the population over age 65 lived in relative poverty, four times higher than the OECD average of $12.6 \%$ (Figure 24). Moreover, the elderly poverty 
rate was three times greater than Korea's $15 \%$ rate for the entire population, in contrast to the OECD area, where it is almost equal. In addition, a third of the elderly in Korea are in absolute poverty, defined as an income below the minimum cost of living. Moreover, the elderly have high debt. For the over 60 age group, household debt amounted to $73 \%$ of their financial assets, compared to the national average of $64 \%$. In Germany and the United States, the ratio was around 20\% (J. Kim, 2015). High poverty contributed to a high elderly suicide rate, which rose from 35 (per 100000 persons) in 2000 to 82 in 2010, with financial difficulty the major cause, according to a government survey (Statistics Korea, 2010). It was far above the OECD average of 22, although the Korean rate fell to 55.5 in 2014, against the backdrop of greater government focus on the issue.

Many elderly had assumed that their children would provide for them, thus making it unnecessary to prepare financially. However, a quarter of the elderly are living alone. The high elderly poverty rate reflects both the decline in family support and the weakness of other private and public sources of old-age income support:

- The National Pension Scheme (NPS), created in 1988, provided old-age pension benefits to only $32.1 \%$ of the elderly in 2015 . Moreover, pension benefits were only $23.5 \%$ of the average wage.

- The Basic Pension (introduced as the Basic Old-Age Pension System in 2008), was doubled to $200000 \mathrm{KRW}$ (USD 175 or $6.2 \%$ of the average wage) in 2014 (Figure 29). It is given to around $70 \%$ of the elderly, which is high compared to the average of $24 \%$ for first-tier safety-net pensions in the OECD (Panel B). It thus spreads resources very thinly over a large segment of the older population.

- The BLSP eligibility criteria, which exclude elderly with the possibility of assistance from family members and impose limits on asset holdings, were relaxed in 2015, boosting the share of elderly receiving benefits from $6.3 \%$ to $6.8 \%$.

- The company pension system introduced in 2005 covered 52\% of employees who had worked for at least a year (15\% of the working-age population) in 2014.

- Korea ranks last in the OECD in Korea's well-being index on the question of whether people had friends or relatives to depend on in times of need.

Rapid ageing, which will reduce the number of persons in the labour force from 5.1 per elderly person to 2015 to 1.5 by 2050 , and the rising number of single elderly persons will tend to worsen poverty.

The government has a target to reduce the elderly poverty rate to $39 \%$ in 2020 , which would still be three times the OECD average. A faster reduction in elderly poverty would require well-targeted social spending to ensure an adequate minimum level of income for all elderly. The government should focus the Basic Pension on the lowest-income elderly to ensure that they at least escape from absolute poverty (OECD, 2015e; 2014 OECD Economic Survey of Korea). Countries with high safety-net pensions tend to have low poverty rates (Figure 29). In addition, further relaxing the BLSP eligibility criterion could also help reduce elderly poverty.

It is important to make the NPS more effective in reducing poverty in the long run. According to the government's 2013 projection, only 40.9\% of the elderly will receive NPS pensions in 2030 and the pension amount will be kept low by the plan to reduce the targeted replacement rate for those with 40 years of contributions from $50 \%$ to $40 \%$, well below the OECD average of 53\%, by 2030 (OECD, 2015e). Moreover, the average contribution period of recipients over 2030-40 is projected to average 20.6 years, reducing the actual replacement rate to around 20\%. A three-pronged approach is needed. First, the number of contributors should be increased. In 2012, only $37 \%$ of the working-age population paid contributions, well below the rates in other OECD countries, reflecting lower compliance by the self- 
employed, non-regular workers and SME employees (Y. Lee, 2012). Second, the average contribution period should be lengthened to increase the size of benefits. Third, the targeted replacement rate should be kept at its current level of $46 \%$ (excluding the Basic Pension, which has a replacement rate of 5\%).

Figure 29. The first-tier pension benefit in Korea is very low while the coverage is high

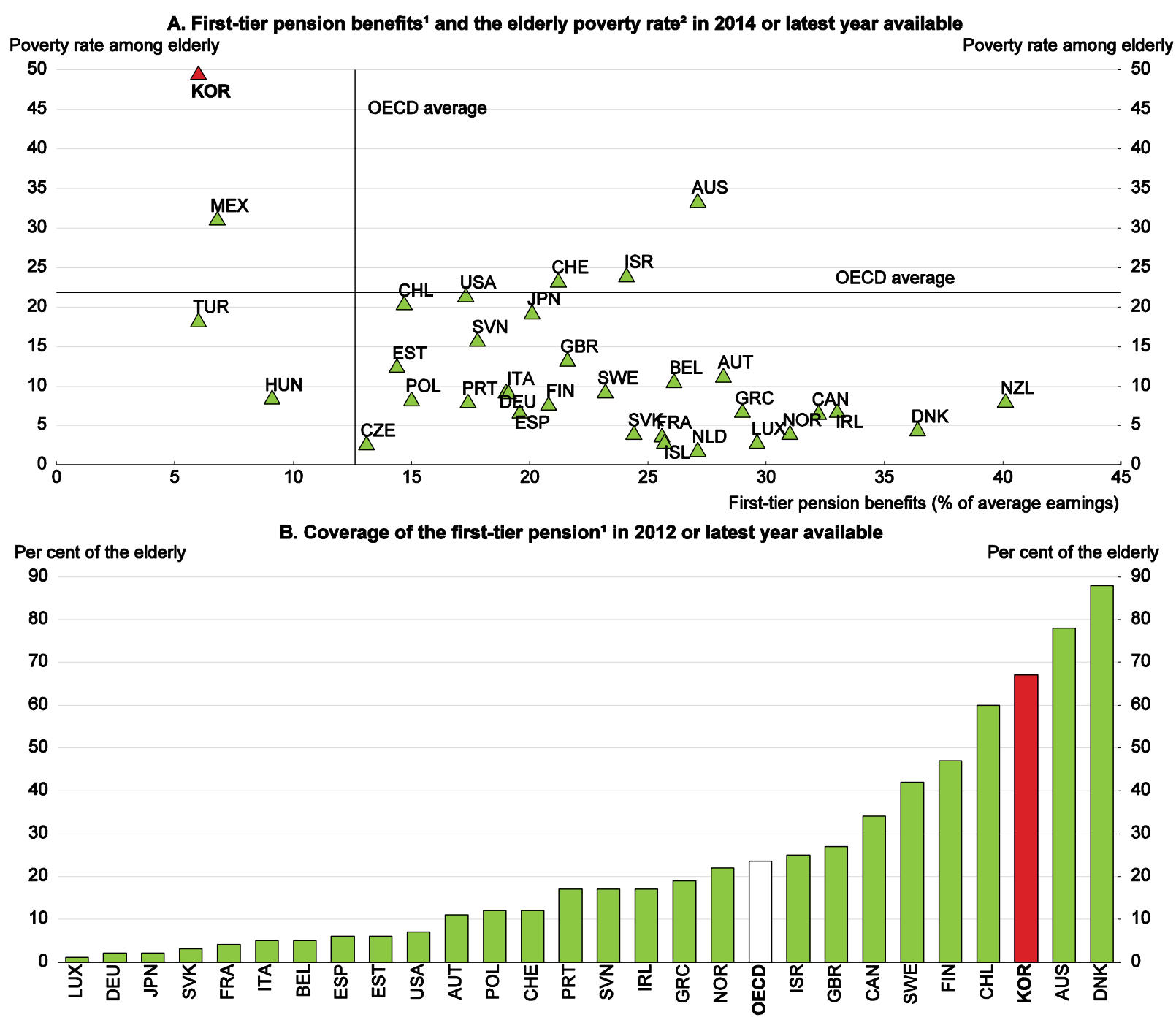

1. The non-contributory, safety-net pension for the elderly. In Korea, this refers to the Basic Pension.

2. Share of the elderly in relative poverty - an income below $50 \%$ of the national median.

Source: OECD (2015e), Pensions at a Glance.

Even with the cut in the replacement rate to $40 \%$ and the planned hike in the pension eligibility age from 61 to 65 in 2033, NPS spending is set to rise much more than revenue (Figure 30). There are three options to sustain public pension systems: cutting benefits, raising the pension eligibility age and increasing revenue. A $40 \%$ targeted replacement rate would be too low, given the short average contribution period. A more rapid hike in the pension eligibility age, under current labour practices, would create hardship by lengthening the gap between when workers leave firms and when they receive a public pension. The best option, therefore, is to raise more revenue by raising the contribution rate from its relatively low level of $9 \%$. The adjustment of the contribution rate should begin as soon as possible, as delays only make the necessary increase larger (2014 OECD Economic Survey of Korea). 
Figure 30. The National Pension Scheme is projected to fall into deficit in 2044

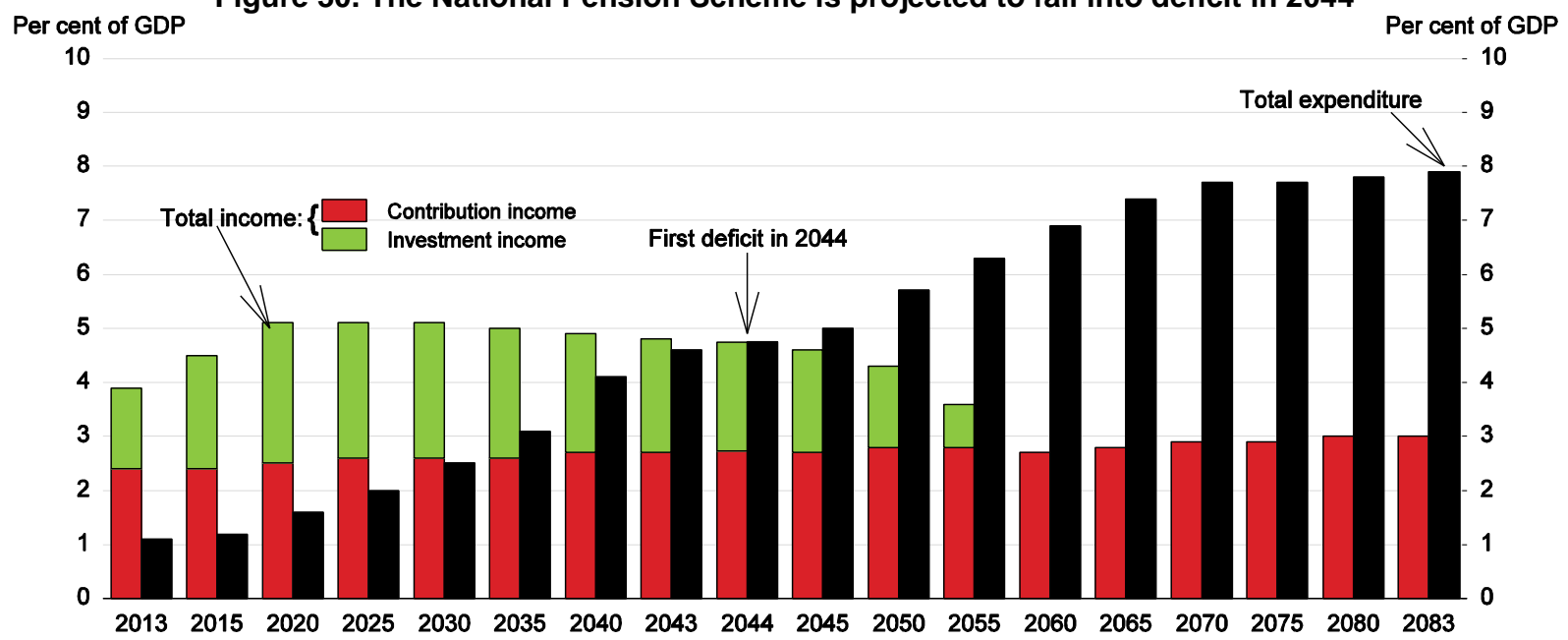

Source: National Pension Research Institute (2013).

Achieving adequate income for the elderly requires a multi-pillar approach. In addition to reforming the NPS, it is important to increase private savings by developing the company pension system and individual pension savings. The introduction of company pensions has been hindered by workers' attachment to the so-called retirement allowance - which requires firms to pay departing employees a lump-sum separation payment equivalent to at least one month of wages per year of work. The government has recently reduced the favourable personal income tax treatment of the retirement allowance. It will be important to assess the effectiveness of this measure in promoting the adoption of company pensions. Individual Pension Accounts should also be strengthened, in part by increasing the penalties for early withdrawal prior to retirement and providing more favourable treatment of existing contracts. 


\section{Box 4. Recommendations for labour market reforms to promote inclusive growth}

\section{Key recommendations}

- Break down dualism by relaxing employment protection for regular workers and making it more transparent, raising the minimum wage and increasing social insurance coverage and training for non-regular workers.

- Increase the take-up of maternity and parental leave systems by enforcing compliance and raising the benefit level for parental leave.

- Enhance childcare quality by making accreditation mandatory and strengthening competition.

- Reduce labour market mismatch for young people by expanding Meister vocational schools and the WorkStudy Dual System, thereby enhancing links between schools and firms, and basing curriculum on the National Competency Standards.

- Accelerate the adoption of the wage peak system and expand education for older persons with low skills to extend their careers at companies.

- Focus the Basic Pension on the elderly with the lowest incomes to reduce the high rate of poverty among those over age 65.

- Expand the coverage of the National Pension Scheme to reduce poverty in the long run.

\section{Other recommendations}

- Extend the limit on fixed-term contract from two years to four.

- Increase the coverage and the generosity of the Earned Income Tax Credit to reduce poverty and strengthen work incentives.

- Expand company pensions and strengthen personal pension plans to create a strong multi-pillar system to ensure adequate income for the elderly. 
ECO/WKP(2016)49

\section{REFERENCES}

Chang, J. and B. Lee (2013), "Increasing Income Inequality and Policy Options in Korea", e-Labour News Issue Papers, No.129, Korea Labour Institute, Sejong.

Choi, K. (2014), “Korea's Income Inequality: The Trend and Major Issues”, in Studies on Policies for Korea's Social Cohesion, edited by Y. Kim, Korea Development Institute, Sejong.

Cools, S., J. Fiva and L. Kirkebøen (2011), "Causal Effects of Paternity Leave on Children and Parents", CESifo Working Papers No. 3513, Munich.

Dao, M., D. Furceri, J. Hwang, M. Kim and T. Kim (2014), "Strategies for Reforming Korea's Labour Market to Foster Growth", IMF Working Paper, No. WP/14/137, Washington, DC.

Economic and Social Development Commission (2015), The Tripartite Agreement on Structural Reforms of the Labour Market, Seoul.

Hong, S. and I. Lee (2014), "Fathers' Use of Parental Leave in Korea: Motives, Experiences and Problems", Korean Women's Development Institute, Seoul.

Huerta, M., W. Adema, J. Baxter, W. Han, M. Lausten, R. Lee and J. Waldfogel (2013), “Fathers' Leave, Fathers' Involvement and Child Development: Are They Related? Evidence from Four OECD Countries", Social, Employment and Migration Working Papers, No. 140, OECD Publishing, Paris.

Ikemoto, M. and S. Hang (2014), Direction of Female Employee Support Comparing Japan and Korea, Japan Research Institute, Tokyo (in Japanese).

Jones, R. (2013), "Education Reform in Korea", OECD Economics Department Working Papers, No. 1067, OECD Publishing, Paris.

Jones, R. and J. Lee (2016), "Raising Korea's Productivity Through Innovation and Structural Reform", OECD Economics Department Working Papers, No. 1324, OECD Publishing, Paris.

Jun, S. and H. Lee (2015), "Status, Performance, and Challenges of the Work-Study Dual System", The HRD Review, Vol. 2015/01, Korea Research Institute for Vocational Education \& Training, Sejong (in Korean).

Kahn, L. (2010), "Labour Market Policy: A Comparative View on the Costs and Benefits of Labour Market Flexibility", CESifo Working Papers, No. 3140, Munich.

Kang, K. et al. (2014), "The Economic and Social Performance Analysis of the Work-Study Dual System", Report for the Ministry of Employment and Labour, Korea Research Institute for Vocational Education \& Training, Sejong (in Korean).

Kim, H. and D. Lee (2013), "A Study on Employment Stabilization After Non-Regular Workers' Transition to Regular Status", Korea Labour Review, No. 47, Korea Labour Foundation, Seoul.

Kim, J. (2011), "Women's Career Disconnect and Re-entry into the Labour Market", in Labour Issues in Korea 2010, edited by K. Bae, Korea Labour Institute, Sejong. 
Kim, J. (2015), "Why Household Debt Held by Korean Seniors is Problematic: An International Comparison", Korea Development Institute, Sejong.

Kim, Y. and J. Jeon (2014), Youth Labour Market: Main Characteristics and Policy Implications, Korea Labour Institute, Sejong (in Korean).

Kim, Y. (2015), “The Youth Labour Market in Korea: Current Situation and Employment Policy", eLabour News Issue Papers, No. 162, Korea Labour Institute, Sejong.

Klassen, T. (2012), "The Future of Contractual Mandatory Retirement in South Korea", Canadian Labour Market and Skills Researcher Network Working Papers, No. 93.

Koh, Y., S. Kim, C. Kim, Y. Lee, J. Kim, S. Lee and Y. Kim (2010), "Social Policy", in The Korean Economy: Six Decades of Growth and Development, edited by I. SaKong and Y. Koh, Korea Development Institute, Sejong.

Lee, C. (2015), "Wage Structure Reform and Labour Market Flexibility: The Case of South Korea", Centre for Wage and Job Research, Korea Labour Institute, Sejong, http://www.ilera2015.com/dynamic/full/IL131.pdf.

Lee, H. (2012), “Employers' Position on Reducing Long Working Hours”, Korea Labour Review, Vol. 8, No. 43.

Lee, Y. (2012), “A Study on Old-Age Income Security Policy Measures to Cope with Population Aging and Income Polarization", Research Papers, National Pension Research Institute, Seoul.

Ministry of Employment and Labour (2015), 2014 Employment and Labour Policy in Korea, Sejong.

Nam, J. and S. Kim (2013), "Korean NEETs: Characteristics and Labour Market Performance", Korea Labour Institute Research Project, No. 535, Korea Labour Institute, Sejong (in Korean).

National Pension Research Institute (2013), A Summary of the 2013 Actuarial Projection Result, Seoul.

OECD (2016), OECD Economic Survey of Korea, OECD Publishing, Paris. http://www.oecd.org/eco/surveys/economic-survey-korea.htm

OECD (2015a), Education at a Glance 2015, OECD Publishing, Paris. http://www.oecd-ilibrary.org/education/education-at-a-glance-2015 eag-2015-en

OECD (2015b), In It Together: Why Less Inequality Benefits All, OECD Publishing, Paris. http://www.oecd-ilibrary.org/employment/in-it-together-why-less-inequality-benefitsall_9789264235120-en

OECD (2015c), OECD Employment Outlook 2015, OECD Publishing, Paris. http://www.oecd-ilibrary.org/employment/oecd-employment-outlook-2015_empl_outlook-2015-en

OECD (2015d), OECD Skills Strategy Diagnostic Report: Korea, OECD Publishing, Paris. http://www.oecd.org/skills/nationalskillsstrategies/Diagnostic-report-Korea.pdf

OECD (2015e), Pensions at a Glance 2015, OECD Publishing, Paris. http://www.oecd.org/publications/oecd-pensions-at-a-glance-19991363.htm

OECD (2015f), Taxing Wages 2015, OECD Publishing, Paris. http://www.oecd-ilibrary.org/taxation/taxing-wages-2015 tax wages-2015-en

OECD (2014a), OECD Economic Survey of Korea, OECD Publishing, Paris. http://www.oecd-ilibrary.org/economics/oecd-economic-surveys-korea-2014_eco_surveys-kor$\underline{2014-e n}$ 
OECD (2014b), OECD Employment Outlook 2014, OECD Publishing, Paris. http://www.oecd-ilibrary.org/employment/oecd-employment-outlook-2014_empl_outlook-2014-en

OECD (2013a), OECD Skills Outlook 2013, OECD Publishing, Paris. http://www.oecd-ilibrary.org/education/oecd-skills-outlook-2013_9789264204256-en

OECD (2013b), Strengthening Social Cohesion in Korea, OECD Publishing, Paris. http://www.oecd-ilibrary.org/social-issues-migration-health/strengthening-social-cohesion-inkorea_9789264188945-en

OECD (2013c), The Survey of Adult Skills: Reader's Companion, OECD Publishing, Paris. http://www.oecd-ilibrary.org/education/the-survey-of-adult-skills_9789264204027-en

OECD (2012), OECD Economic Survey of Korea, OECD Publishing, Paris. http://www.oecd-ilibrary.org/economics/oecd-economic-surveys-korea-2012_eco_surveys-kor2012-en

OECD (2011), Doing Better for Families, OECD Publishing, Paris. http://www.oecd-ilibrary.org/social-issues-migration-health/doing-better-forfamilies_9789264098732-en

OECD (2011), Doing Better for Families, OECD Publishing, Paris. http://www.oecd-ilibrary.org/social-issues-migration-health/doing-better-forfamilies 9789264098732-en

OECD (2007), Jobs for Youth: Korea, OECD Publishing, Paris. http://www.oecd-ilibrary.org/employment/jobs-for-youth-des-emplois-pour-les-jeunes-korea2007_9789264040809-en

Rowley, C. and H. Yang (2008), "Performance Management in South Korea", in Performance Management Systems: A Global Perspective, edited by A. Varma, P. Budhwar and A. Denisi, Routledge.

Samsung Economic Research Institute (2010), "Report on the Current Condition of Korean Working Moms", CEO Information, No. 771 (in Korean).

SBS News (2014), "Since You Are Pregnant, Get Out: Companies Force Pregnant Women to Leave" (in Korean), http://news.sbs.co.kr/news/endPage.do?news_id=N1002628656\&plink=ORI.

Statistics Korea (2010), Outcome of Social Survey 2010: Family, Education, Health, Security and Environment, Daejeon (in Korean).

Vinnicombe, S., E. Doldor, R. Sealy, P. Pryce and C. Turner (2015), The Female FTSE Board Report 2015, Cransfield University, School of Management.

Walker, R. (2014), “Is the Gender Pay Gap Closing?", The Globalist, http://www.theglobalist.com/genderpay-gap-closing/.

World Values Survey (2015), World Values Survey Wave 6 (2010-14), http://www.worldvaluessurvey.org/WVSDocumentationWV6.jsp.

Yang, K. (2015), "With Jobs Scarce, South Korean Students Linger on Campus", Reuters News, 1 January.

Yang, S. (2012), "Policy to Reduce the Long Work Hours in Korea", Korea Labour Review, Vol. 8, No. 43.

Yoo, G. (2013) "Issues on and Policy Directions for the Minimum Wage", KDI Focus, No. 32, Korea Development Institute, Sejong. 
Yoo, J. (2012), "FKTU Policy Directions to Improve Long Working Hours", Korea Labour Review, Vol. 8, No. 43 .

Yoon, J. (2014), "Maternity Protection and Its Effect on Employment", e-Labour News Issues Papers, No. 149, Korea Labour Institute, Sejong.

Yun, H., I. Kim and H. Kwon (2014), "Nine Observations on Korean Child Care Support and their Policy Implications", KDI Focus No. 34, Korea Development Institute, Sejong. 